\title{
Modeled Atmospheric Radon Concentrations from Uranium Mines
}

J. G. Droppo

April 1985

Prepared for the U.S. Environmental Protection Agency under a Related Services Agreement with the U.S. Department of Energy Contract DE-AC06-76RLO 1830

Pacific Northwest Laboratory Operated for the U.S. Department of Energy by Battelle Memorial Institute 
Although the research described in this article has been funded wholly or in part by the United States Environmental Protection Agency (EPA), it has not been subjected to EPA review and therefore does not necessarily reflect the views of EPA and no official endorsement should be inferred.

\title{
DISCLAIMER
}

This report was prepared as an account of work sponsored by an agency of the United States Government. Neither the United States Covernment nor any agency thereof, nor any of their employees, makes any warranty, express or implied, or assumes any legal liability or responsibility for the accuracy, completeness, or usefulness of any information, apparatus, product, or process disclosed, or represents that its use would not infringe privately owned rights. Reference herein to any specific commercial product, process, or service by trade name, trademark, manufacturer, or otherwise, does not necessarily constitute or imply its endorsement, recommendation, or favoring by the United States Government or any agency thereof. The views and opinions of authors expressed herein do not necessarily state or reflect those of the United States Government or any agency thereof.

\author{
PACIFIC NORTHWEST LABORATORY \\ operated by \\ BATTELLE \\ for the \\ UNITED STATES DEPARTMENT OF ENERGY \\ under Contract DE-AC06-76RLO 1830
}

\begin{tabular}{|c|c|}
\hline Printed in the & of America \\
\hline & \\
\hline National Tecl & Ition Service \\
\hline United Stares & f Commerce \\
\hline 5285 & ad \\
\hline Spring & 22161 \\
\hline & \\
\hline & \\
\hline & \\
\hline & Price \\
\hline Pages & Codes \\
\hline 001.025 & 102 \\
\hline $026-050$ & 103 \\
\hline 051.075 & $A 04$ \\
\hline $076-100$ & 105 \\
\hline 107.125 & $A 06$ \\
\hline $126-150$ & $A 07$ \\
\hline 151.175 & $A 00$ \\
\hline $176-200$ & $A 09$ \\
\hline $201-225$ & A010 \\
\hline $226-250$ & A011 \\
\hline 251.275 & 1012 \\
\hline $276-300$ & $A 013$ \\
\hline
\end{tabular}


MODELED ATMOSPHERIC RADON CONCENTRATIONS

FROA IIRANIUM MINES

J. G. Droppo

Apri! 1985

Prepared for

the U.S. Envilmental Protection Agency

under a Related Services Agreenent with the U.S. Department of Energy under

Contract DE-ACO6-m GLL 1830

Jay Sflhenek, Ecte Project Manager

Pacific Northwest Laboratory

Richland, Washington 9935 
. 
SUPHetari

Gecause elevated radon concentrations have been reported in the exhaust air vents from operating underground urantum mines, the U. S, Environmental protection Agency (EPA) under the Ciean Air Act is assessing the heath impact of air emiss tons of radon from various sources. The radon entssions from these urantur mines matimpact local workers and residents. Pactic lorthicest Laboratory (PNL) under an Interagency Agreement with EPA is using a computer modelirg approach to study these increases of radon concentratons in the air downitid from the mines.

To help Eptassess potential contribution of mine amissions to measured radon concentrations, the long-term average ground level radon concentrations resultony from mine entssions alone were computed. Using the cou Industrial Source Complex (ISC) baussian dispersion model, impacted areas were defined for four concentration levels: $0.1,0.2,0.5$, and $1.0 \mathrm{pCl} / \mathrm{L}$.

Rodon concentrations ware deternined for multiple mine operations in an intens" qe mining area, for a nodel mine, and for 14 case study nines. The multiple mine compuations are made far emissions from over 100 vents located in the Anbrosia lake Reglon of New Mexico. As for tha individual mines, the range of radon concentrations was computed based on both plume rise and no plume pise.

A rodeling approach was chosen that best represents actual conditions and maxinizes the confidence in the predicted radon concentrations. At though curren: modeling techniques for transport and ispersion of contarinants are not always reliable in predicting short-term concentrations, these nodels do give reasonably good estimates of long-terin average concentrations, which are of concern in this study. Where possible, the model inputs were based on actual emission measurenents and mine locations. Local meteorologtcal cond ï. tions were used when avallable. The nodel dispersion parameters originated fron studies made at 5 ites quite sinilar to the mining areas. concentrations of nain interest are at relatively close distances where these model paraneters have thefr largest data base, and the straight-line assuption of the nodel is appropriate. 
Radon concentration contour maps are also presented for these mines. Results for the 14 case study mines were plotted on mas containing population data for the selected mine areas. These maps cover a range of plutie rise assurtations.

The radon concentrations were nainly a function of emisson rates and plume rise. Alde variation of measuratine emission rates produced a correspending range in computed radon concentrations. The importance of plume rise was also evikent in the results. Differences also ocurred as a result of veriations in local alspersion climatology, number of vents, uent patterns, vent size, and exhast flow. Multiple mine modeling indicated that the radon concentrations were increased as a result of overlapplong nine emiscions.

The vertical or horizontal orientation of the vents are important in the calcalation of concentrations near the vents. The plume rise for vertical vents results in low ground level concentrations neat the vents. No plute rise for horizonta vents results in high ground level radon concentrations near the vents. The importance of the release ortentation becones progressively less at greater distances from the mine vents. At distances on the arder of $10 \mathrm{~km}$, the predicted raton concentrations for horizontal and vertical vent raleases hava equivalent mantudes. 


\section{CONTENTS}

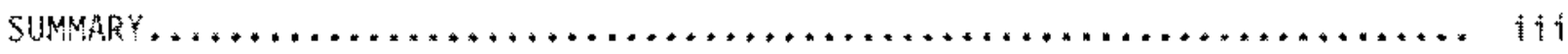

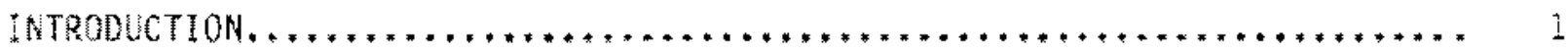

METHODOLOGY $\ldots \ldots * \ldots \ldots * \ldots \ldots \ldots \ldots \ldots \ldots \ldots \ldots \ldots \ldots \ldots \ldots \ldots \ldots \ldots \ldots \ldots+\ldots \ldots \ldots \ldots, 2$

INDIVIDUAL MINE IMPHCT $\ldots \ldots \ldots \ldots \ldots \ldots \ldots \ldots \ldots \ldots \ldots \ldots \ldots \ldots \ldots \ldots \ldots \ldots$

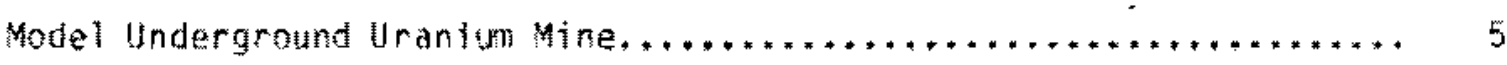

Gase Study mes.......................................

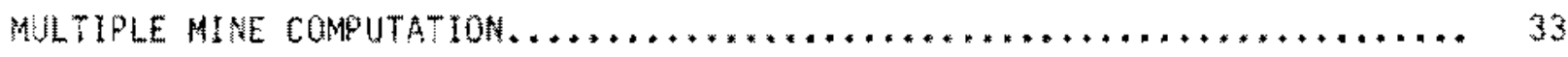

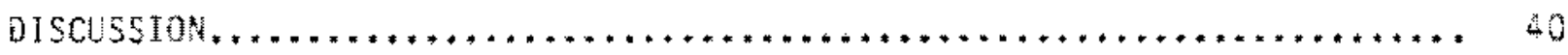

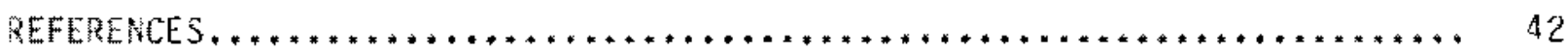

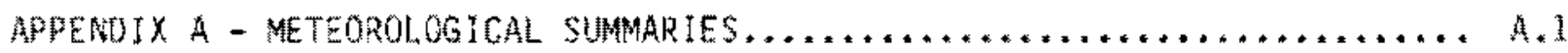

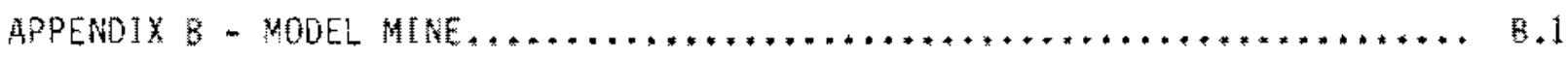

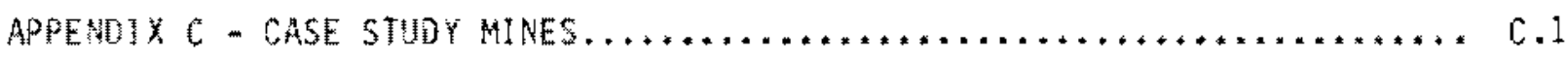




\section{FIGURES}

1 Mode1 Reference Underground Mine............................. 6

2 Computed Incrementa i Radon Concentrations, $p C i / \mathrm{L}$, Around the Model Underground Mine Assuriting ko Plume Rise., .............

3 Computed Incremental Radun Concentrations, pot/L, Around the Model Underground Mine With Plume Rise.................... ह

4 Est Al lowing for P7ume Rise at Case Study Mine $1 \ldots \ldots \ldots \ldots \ldots \ldots \ldots \ldots \ldots \ldots \ldots 12$

5 Estimated Incremental Radon Concentration Contours, $\mathrm{pCi} / \mathrm{L}$, Allowing for Plume Rise at Case Study Mine $2 \ldots \ldots \ldots \ldots \ldots \ldots \ldots \ldots \ldots \ldots$

6 Estinated Incremental Radon Concentration Contours, pCi/L,

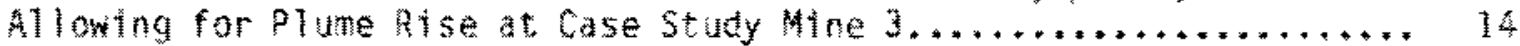

7 Estimated Incremental Raton Concentration contours, pei/L,

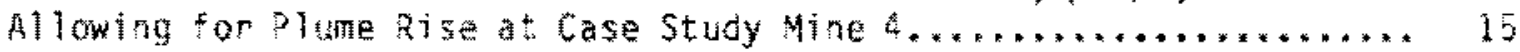

8 Estimated increnental Radon Concentration conmours, pCi/L, Allowing for Plume Rise at Case Study Mine $5 \ldots \ldots \ldots \ldots \ldots \ldots \ldots \ldots \ldots . \ldots . \ldots . \ldots 16$

9 Estimated incremental Radon Concentration Con ours, pCi/L, All owing for Pi une Rise at Case Study Mine $5 \ldots \ldots \ldots \ldots \ldots \ldots \ldots \ldots \ldots \ldots$. 1 ?

10 Estimated Increnental padon Concentration Contours,

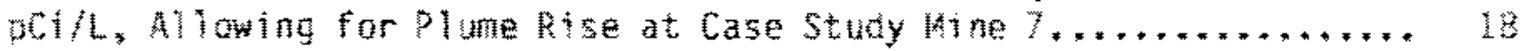

II Estumated Incremental fadon Concentration Contours Allowing

for plume Rise at Case study Mine $8 \ldots \ldots \ldots \ldots \ldots \ldots \ldots * \ldots \ldots \ldots \ldots \ldots \ldots \ldots$

12 Estimated Incremental Radon Concentration Contours, $\mathrm{pCi} / \mathrm{h}$, Allowing for plume Rise at Case Study Mine $9 . . . . . . . . . . . .20$

13 Estinated Increnental Radon Consentration Concours, pCi/L, Allowing for Plume Rise at case Study Mine $10 \ldots \ldots \ldots \ldots \ldots \ldots \ldots \ldots$

14 Estimated Incremental Radon Concentration contours, pei/L, Allowing for Plune Rise at Case Study Mine $13 \ldots \ldots \ldots \ldots \ldots \ldots \ldots \ldots \ldots \ldots$. 22

15 Estimated Incremental kadon Concentration Contours, $\mathrm{pCi} / \mathrm{L}$, Allowing for Actual vent Configurations, $p C i / L$, at Case Study Mine $11, \ldots . \ldots \ldots \ldots \ldots \ldots \ldots \ldots \ldots \ldots \ldots \ldots \ldots \ldots \ldots \ldots \ldots \ldots \ldots \ldots \ldots \ldots \ldots$ 
16 Estmated Increnental fardon Concentration contours, pCi/L,

Allowing for Actual Vert configurations at Case Study Mine $12 \ldots \ldots \ldots$. 24

17 Estinated Incremental Radon Concentration Contours, pCi/4, Based on a No Plume Rise Assumption at Case Study Mine 2........... 25

18 Estimated Incremental Radon Concentration Contours, $\rho \mathrm{Ci} / \mathrm{L}$, Gased on a No Plume Rise Assumption at Case $5 t u d y$ Mine $7 \ldots . . . . . * * *$. 26

19 Estimated Incremental vadon Concentration contours, pCi/L, Fased on No Plune Rise Assumption at Case study Mine $10, \ldots \ldots \ldots * \ldots \ldots 27$

20 Estinated Increnental Radon Concentration Contours, pCi/L Gased on a No Plume Rise Assutption at Case Study Mine $11, \ldots \ldots \ldots \ldots$. 2 ?

21 Estimated Incremental Radon Concentration Contours, $\mathrm{pC} / \mathrm{L}$, Based on a No Plume Rise Assumption at Case Study Mine $12, \ldots . . . . . .29$

22 Estrinated Increnental Radon Concentration contours, $\mathrm{pCi} / \mathrm{L}$, fased on a No Plune Rise Assumption at Case Study Mine 14,......... 30

23 Avage Incremental fadon Concentratons, petilL, Downind of the Six Mines with Measured Release Characteristics Based on a Genertic Release of 11,000 Ci/yr for Each Mine............ 32

24 Detailed Map of Selected Multiple Mine Area Showing Vent Locations... 34

25 Estimated Incremental Radon Concentration Contours, $\mathrm{pCi} / \mathrm{L}$, Based on Mutiple Mine Emissions Using a No Plume Rise Assumption* . . 37

26 Estimated Incremental Radon Concentration Contours, pCill, based on Multiple Mine Enisstons Allowing for Plume Rise and All

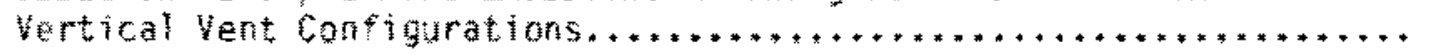

27 Estimated Incremental Radon Concentration Contours, pCi/L, Based on Multiple Mine Emissions Allowing for Plume Rise at All Vents Except Five Morizontal Vents at Case Study Mines 11 and $12 . . .$. . 


\section{TABLES}

1 Estindates of Radon Concentrations in Air at Selected Distances

from the Model Underground Uranium Mine........................ 9

2 Summary of Case Study 14 nes..., $\ldots \ldots \ldots \ldots \ldots \ldots \ldots \ldots \ldots \ldots \ldots \ldots \ldots \ldots \ldots, 10$

3 Source Tems for Multiple Nine Computation. $* \ldots \ldots \ldots \ldots \ldots \ldots \ldots \ldots \ldots \ldots \ldots *$ 35

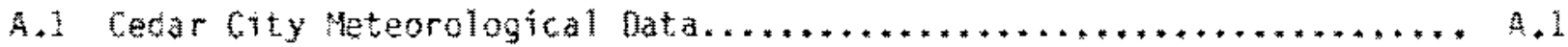

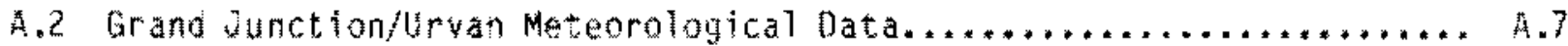

A.3 Grand Junction/Urvan/Lisban Meteorological Data....................3

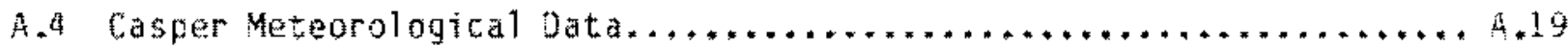

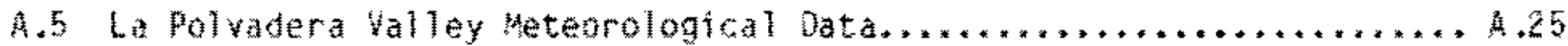

A.5 Gallup Meteorologital dut $\ldots \ldots \ldots \ldots \ldots \ldots \ldots \ldots \ldots \ldots \ldots \ldots \ldots \ldots \ldots \ldots \ldots, \ldots \ldots$

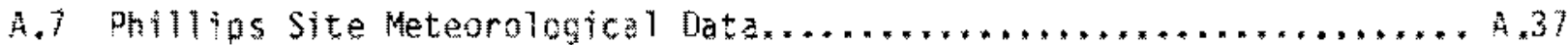

A.8 Nose Rock Meteorological Data...............................43

B.1 Model Mine Computed Raton Concentrations Without Plume Rise......... B.?

3.2 Model Mine Computed Raden Concentrations hith Plume Rise $\ldots \ldots \ldots \ldots, 0.3$

C.1 Sumary of Information used in Modeling Radon concentration at selected Mines........................................ c.?

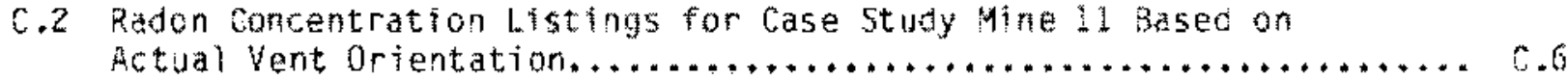

C.3 Radon Concentration Listings for Case Study Mine 12 Based on Actual Vent orientation............................... 6.7

6.4 Radon Concentration Listings for Gase Study Wine 11 with

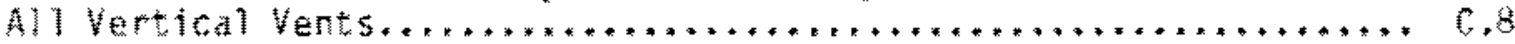

C.5 Racon Concentration Listings for Case Study Mine 12 With All Vertical Vents........................................... 
MTROUUTTION

Uranium mining and milling operations result in the release of radon from nurierous sources of various types and strengths. The U.S. Environmentat Protection Agency (EPA) under the Clean Air Act, is assessing the heath impact of air emistions of radon from underground uranitum mines. In this case, the raton emisstuns nay impact workers and residents in the mine vicinty. To a in in this astessment, the Epa needs to know how mine releases can affect the radon concentrations at populated locations. To abtain this type of information, Pacific forthwest Laboratory used the radon emissions, release characteristics and local meteorological conditions for a number of mines to model increnental radon concentrations.

Long-term, average, incremental radon concentratons were conputed based on the best azailable Information on release rates, plune rise paraneters, number and locations of vents, and local ditpersion climatology. Calculations are made for model mine, individual mines, and multiple mines.

Ou approach was to start with a general case and then consider specific cases for comparison. Amodel underground uranium mine was used to provide defintion of the order of magnitude of typical impacts. Then computations

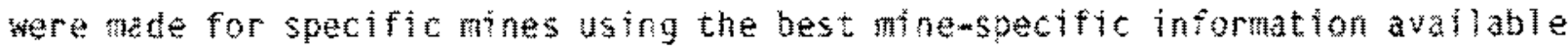

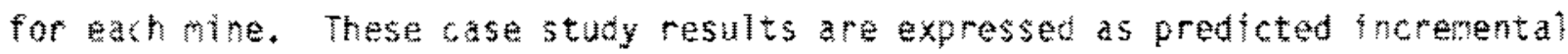
radon concentration contaurs plotted on maps wh local population data from a previous study (Bruno et a1. 1984). Finally, the effect of possible overlap of radon releases from nearby mines was studied by calculating cumulative radon concentrations for multiple mines in a region with many mes.

The dispersion model moling assurptions, data sources, computationa procedures, and results are doctmented in this report. The nethodology is described in the first section. Then the nat tho sections give single thine and mu tiple mine modeling resuls. The find section discusses these results. 
METHODOLOGY

A dispersion model is used to estimate the airborne radon concentrations expected to result from mine radon enissions. Concentrations are expected to be greatest over the first several kilometers surrounding the mine. Assuming the terrain and meteorology are relatively uniform over these distances, a straight line caussian model is appropriate. The EPA's interest in long-term average concentrations is best met by using a climatological dispersion model. Multiple vent locations dictate that the model be able to handle sources at different locations. The model should also be able to handle various horizontal and vertical release configurations,

A model meeting the above criteria was selected for use from EPA's User's Network for App?ied Modeling of Air Poliution (UMAMAP) series of atmospheric dispersion node1s. The use of a uNAMAP model ensures avaliablitity of the nodel to anyone to make addfional computations or related studies. In addition, the user's guide for the selected model provides detailed model documentation.

The model used is the Industrial Source Cumplex Long-Term dispersion model (ISCLT) (EPA 1979). Volume I of the user's guide gives detalled technical information on formulations used in the ISCLT with user's instructions and Volume II contains sample runs and program code listings.

ISCLT is a climatological dispersion mode?. The input requirements for this study are as follows:

- Meteorological Data-woint frequency tables of wind speed, wind direction, and atmospheric stabllity were obtalned at the nearest site representative of conditions at the uranium mine or mines being studied. Appendix A contains the tables used in the conputations. Hixing height inputs for each mine were obtained fron a report by Hol zworth (1972).

- Source Data-The emission rates and characteristics for each mine vent were defined based on a combination of information from a number 
of sources. These included letters from mine operators, a report by Jackson et a). (1980), and other public sources. Appendices $\mathrm{B}$ and $\mathrm{C}$ list all these information sources.

- Receptor Definition-Computations were made for two sets of receptors or grids. A square grid was used for generating the concentration fsoleth maps. A grid spacing of $0.5 \mathrm{kn}$ was used for single mine computations and $1.0 \mathrm{~km}$ for the multiple mines. A polar grid, centered on the mine shaft, was used to determine detailed downind concentration profiles. Sixteen direction sectors and selected arc distances were used.

- Utspersion Paraneters--1SCLT allows selection of rural, urban or custon dispersion coefficlents. In all computations reported here, dispersion parameters for rural conditions were used.

- Plume Rise--IStLT has plume rise formulations for both heat and momentum generated plume rise. Required inputs are the exhaust temperature, vertical exit velocity, release height, and exit size. Fans force the air out of the exhaust vents. Plume rise is computed for vertically oriented vents based on their exit velocity ant size. Horizontally oriented vents do not have any initial vertical velocities, and are assumed not to have any pine rise. The exit temperature is assuned to be close to ambient temperatime. Default parameters are used for defining the atmospheric vertical structure.

Al though detailed information was not available on the actual release heights of the vents, these are releases that occur relatively close to the ground. Typical release heights may vary from near-surface to $4 \mathrm{~m}$. Fixed release helghts of $1 \mathrm{n}$ for vertical vents and 3 fi for vents whout any plume rise (horizontal vents) were assumed. Because the release helghts are relatively low, the plume rise is quite important in increasing the effective plune height:

The extent that plume rise may reduce conputed ground level radon concentrations is uncertain because of the lack of nine plume rise data. The range of affects are considered by computing radon concentrations for both no 
plume rise (horizontal wents) and plume rise (vertical vents). Although the near-surface vent releases are different than release configurations studfed in plume rise from high industrial stacks, the plume rise formulations used in ISCLT should provide reasonable estimates of potential plume rise for mine vents.

The relatively low helght of vent releases makes it uncertain that the computed plume rise will be realized in all cases. Near-release influences such as buildings, walls, hills, and vegetation can easily change local flow characteristics such that downash of the plume octurs. Even when downwash does not occur, the increased local dispersion will tend to decrease plume rise. Insufficient mine vent information was avallable to utilize $15 \mathrm{CL} \mathrm{I}^{\prime} \mathrm{s}$ plune downwash options.

A ground level release wh no plune rise represents the computation case with the bighest computed dowhind radon concentrawons. A release with plume rise represents the case with the lowest radon concentrations. The racon concentrations computed with these two cases will span the range of conditions for various local influences on vent releases.

The procedure for making radon concentration contour piots was as follows. ISCLT was used to compute the incremental radon concentrations for a grtd, as described before, covering the area of interest. Then a linear interpolation plotting program was used to draw $0.1,0.2,0.5$, and 1.0 pet/L concentration contours using the same scale as the mine naps with the population data. The contour plots were then superinposed on the population mine map. 
INDIVIDUAL MINE IMPACT

The incremental airborne radon concentrations were computed both for a model mine and actual individual mines. This section describes assumptions, inputs, and results of these computations.

\section{MODEL UNDERGROUND URANIUM MINE}

Typical incremental radon concentrations in the air around a model underground uranium mine were computed. The wide variation in release parameters and rates for individual mines made the definition of a model mine very difficult. Parameters were defined using a combination of representative and typical values.

A release configuration of five vents was used as in a previous EPA study (EPA 1984). Figure 1 shows the relative location of vents.

A generic radon release rate of $11 \mathrm{kCi} / \mathrm{yr}$ (EPA 1984) was used for the mine. This was equally divided among the five vents for a $2.2 \mathrm{kCi} / \mathrm{yr}$ release for each vent. The emission rate of $11 \mathrm{kCi} / \mathrm{yr}$ was an average rate for eight mines chosen by EPA where emission rates had been measured. These mines had produced uranium ore for at least 10 years at that time and been included in the population study around underground uranium mines (Bruno et al. 1984).

The exit velocity and exit diameter were based on the average values available from six of fourteen case study mines. These six mines had specific emission information available. A physical release height of $1 \mathrm{~m}$ was assumed for each model mine vent. The Ambrosia Lake meteorological data from the Phillips mine site were used for the model mine (Appendix A, Table A-7). Model mine release characteristics are listed in Appendix $B$ along with tables of computed radon concentrations.

The radon concentration patterns computed for the model mine are given in Figures 2 and 3 for the cases of no plume rise and plume rise, respectively. Table 1 contains computed radon concentrations for the model mine at selected distances from the mine shaft. The maximum is the highest value that occurred in any of the sixteen direction sectors. The average value of all sectors at 


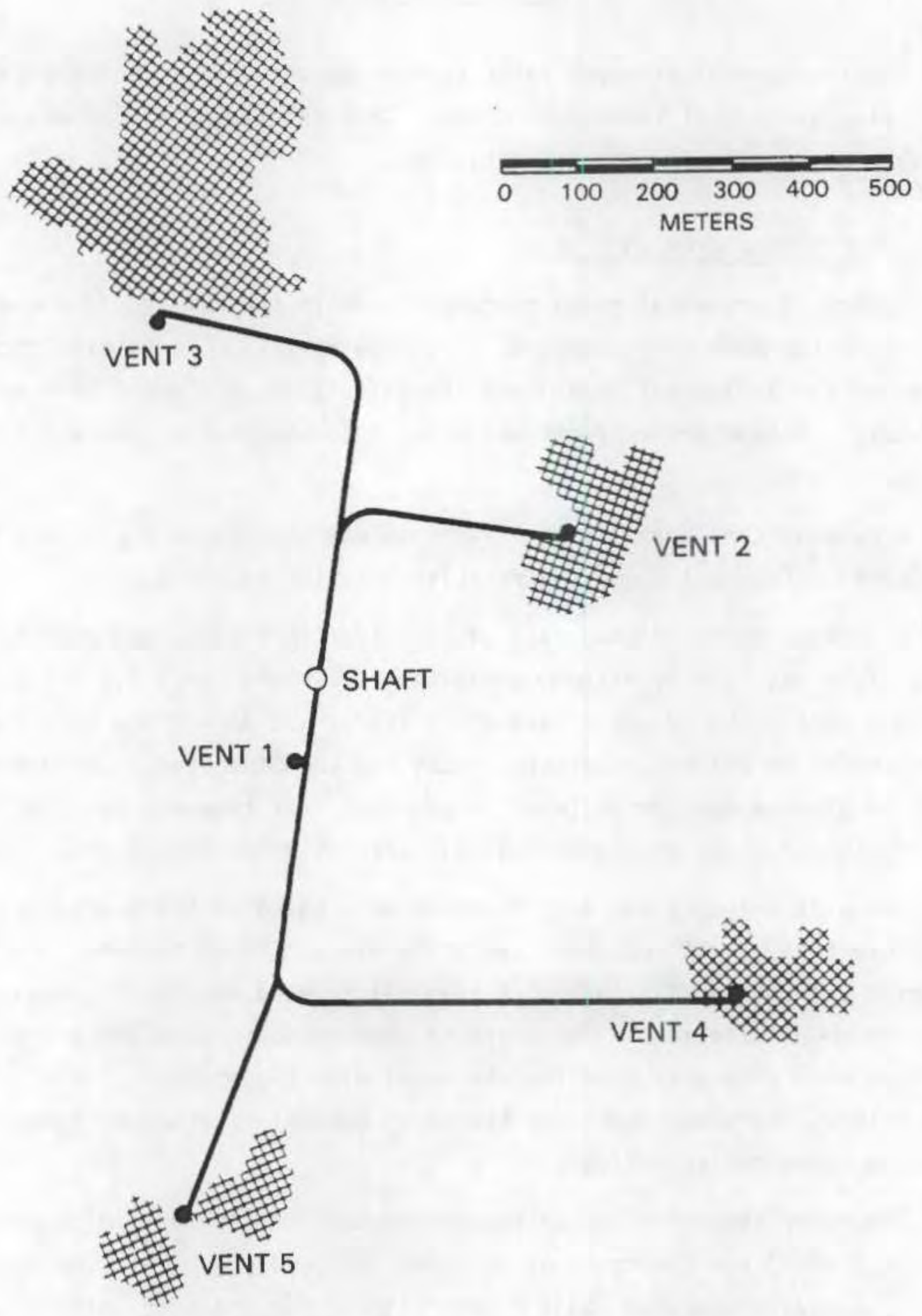

FIGURE 1. Model Reference Underground Mine 


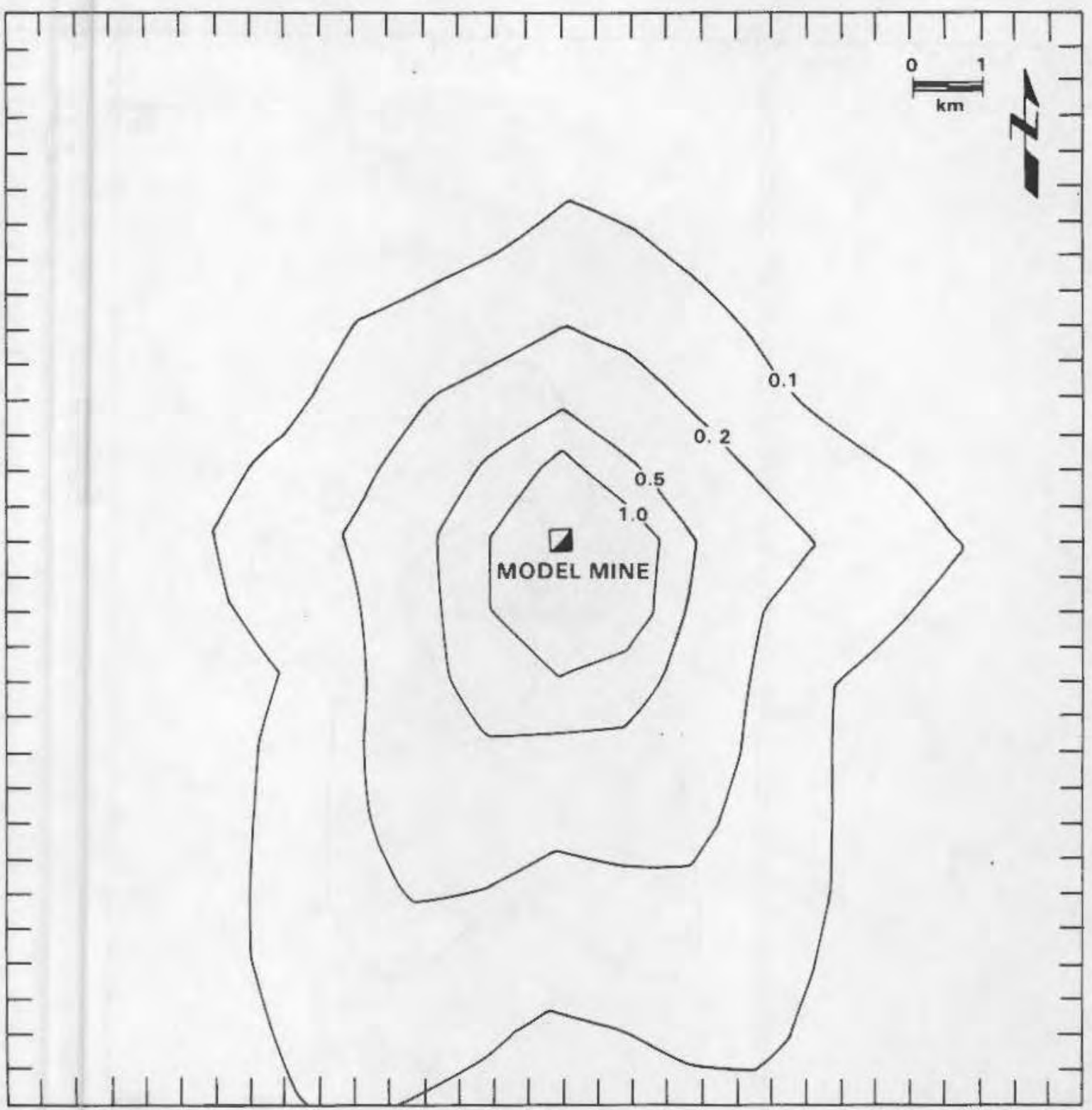

FIGURE 2. Computed Incremental Radon Concentrations, $\mathrm{pCi} / \mathrm{L}$, Around the Model Underground Mine Assuming No Plume Rise 


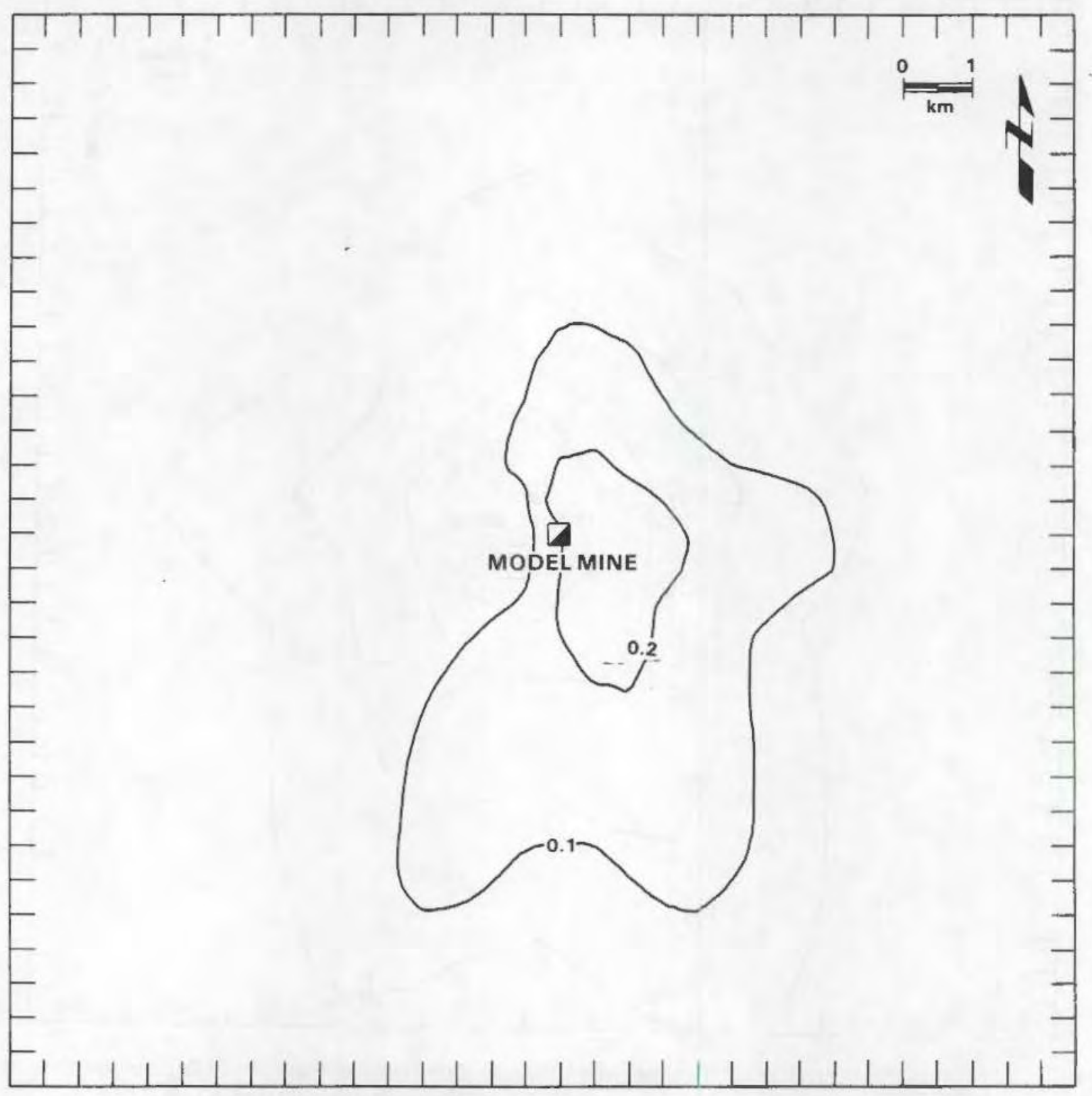

FIGURE 3. Computed Incremental Radon Concentrations, $\mathrm{pCi} / \mathrm{L}$, Around the Model Underground Mine With Plume Rise 
TABLE 1. Estimates of Radon Concentrations in Air at Selected Distances from the Model Underground Uranium Mine

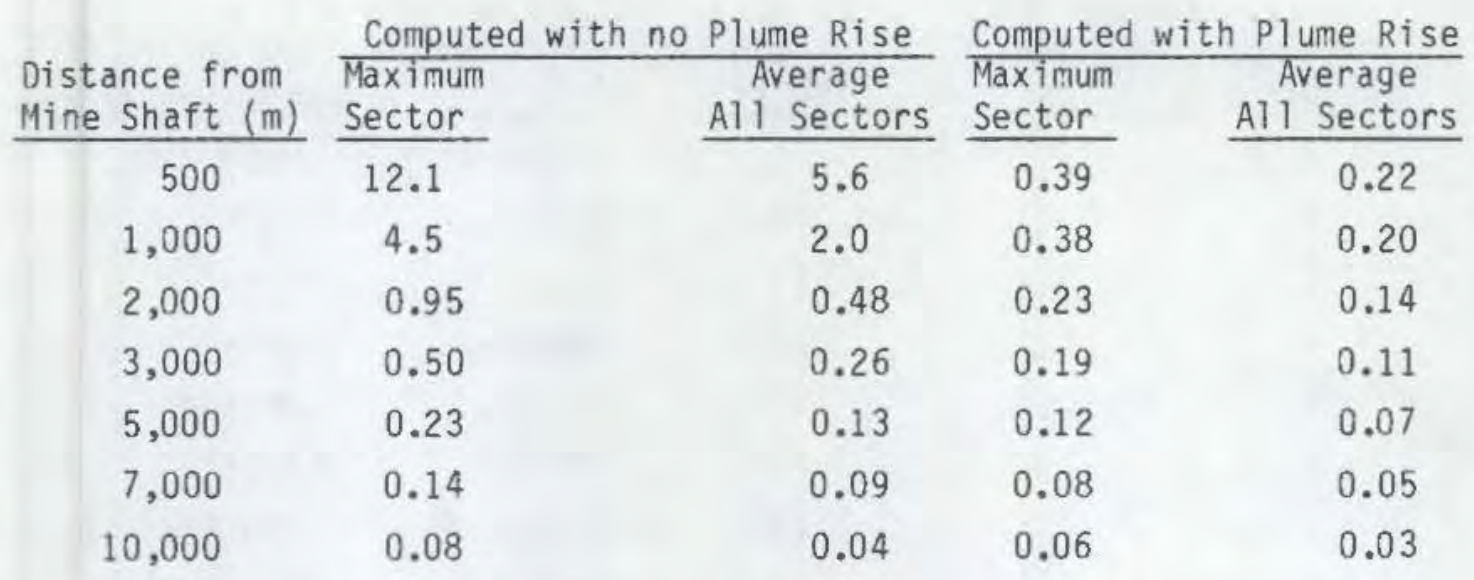

each distance are given for definition of the impact. Values are given for both plume rise and no plume rise. Distances are measured from the model mine shaft. In all cases the maximum is about a factor of two higher than the average.

The mine shaft is used as a central point to define downwind distances. The five vent releases for the model mine occur within about one square kilometer area around the mine shaft. As a result, the concentrations computed for the first several kilometers can be expected to partly reflect the distribution of the five vents.

\section{CASE STUDY MINES}

EPA selected the case study or specific mines from mines where actual radon measurements were made (Jackson 1980) and also were included in population studies around mines (EPA 1983). Mines were selected based primarily on the existence of population in the mine vicinity and whether the locations provided a cross section of different mine sites.

Table 2 contains a summary of the case study mine characteristics. Of the 14 mines selected, measured radon emissions were available for six mines. The values given for the emissions are based on the sum of average values for the vents at each mine. The average values of release parameters for the model mine were used for the mines lacking site-specific data. Local meteorological 


\section{TABLE 2. Summary of Case Study Mines}

\begin{tabular}{|c|c|c|c|c|}
\hline $\begin{array}{c}\text { Mine } \\
\text { Number }\end{array}$ & $\begin{array}{l}\text { Number of } \\
\text { Modeled } \\
\text { Vents } \\
\end{array}$ & $\begin{array}{c}\text { Total Radon } \\
\text { Emission } \\
(\mathrm{kCi} / \mathrm{yr}) \\
\end{array}$ & $\begin{array}{l}\text { Type of } \\
\text { Emissipn } \\
\text { Data }\end{array}$ & $\begin{array}{l}\text { Source of } \\
\text { Meteorology (b) }\end{array}$ \\
\hline 1 & 1 & 11 & Generic & Regional \\
\hline 2 & 11 & 2 & Measured & Local \\
\hline 3 & 8 & 11 & Generic & Local \\
\hline 4 & 6 & 11 & Generic & Local \\
\hline 5 & 5 & 11 & Generic & Regional \\
\hline 6 & 1 & 11 & Generic & Local \\
\hline 7 & 7 & 25 & Measured & Regional \\
\hline 8 & 5 & 11 & Generic & Regional \\
\hline 9 & 2 & 11 & Generic & Regional \\
\hline 10 & 4 & 8 & Measured & Regional \\
\hline 11 & 13 & 9 & Measured & Local \\
\hline 12 & 4 & 5 & Measured & Local \\
\hline 13 & 5 & 11 & Generic & Local \\
\hline 14 & 2 & 0.5 & Measured & Regional \\
\hline
\end{tabular}

(a) Generic = average generic values were used for exit velocity and diameter because specific information was not available. Measured $=$ measured values of exit velocity and diameter for each vent were used.

(b) Regional = meteorological surface observations from station in the region of the site; Local = meteorological data in the immediate area of the mine.

data were used for 7 of 14 mines. The information in this table provides a framework for understanding the case study results presented later. Appendix $C$ contains additional details concerning sources and characteristics of model inputs and output radon concentration tables for two mines.

The case study mine computations are made to assess the effects of various influences on radon concentrations. Generic input values were used where data were not available to allow comparisons based on the available site-specific data. 
Even for the mines where emission measurements were made, these data apply only to the period or year when the measurements were made. They may, or may not, represent current or long-term operations. However, radon concentrations computed using these measured emission values will provide general guidance for the range of values possible from operating mines.

Figures 4 to 14 contain radon contour plots for 11 of the case study mines. These are based on measured and generic radon emission rates as 1 isted in Table 2. These plots are based on computed plume rise at all vents. The six horizontal vents at mines 11 and 12 were assumed to be oriented vertically without changing the exit sizes and velocities. As expected the higher radon concentrations occur around the location of vents which were generally in the immediate area of the shafts. All computed concentrations were less than $0.1 \mathrm{pCi} / \mathrm{L}$ at case study mine 11 , mine 12 , and mine 14 , and thus no contour plots are given for these mines.

Figures 15 and 16 contain contour plots based on actual vent configurations (horizontal or vertical) for the two mines that are known to have horizontal vents. Mine 11 is modeled with three horizontal and ten vertical vents. Mine 12 has two horizontal and two vertical vents. These horizontal vents are modeled as an area release with no plume rise. These computations are based on measured radon emission rates (Table 2). Although no information was found to indicate any of the other case study mines have horizontal vents, some may have these types of vents.

Figures 17 to 22 contain radon contour plots for the six mines with measured emission data (Table 2) computed for no-plume-rise releases. These plots are also based on measured radon emission rates to provide a means for evaluating the plume rise results given in preceding figures.

Average downwind radon concentrations were computed for the six mines with measured release characteristics. Instead of the measured emission rates used in Table 2, the model mine release rate of $11 \mathrm{kCi} / \mathrm{yr}$ was used for each mine. Measured vent exit sizes and velocities were used assuming only vertical releases. The six horizontal vents at mines 11 and 12 were assumed to be 


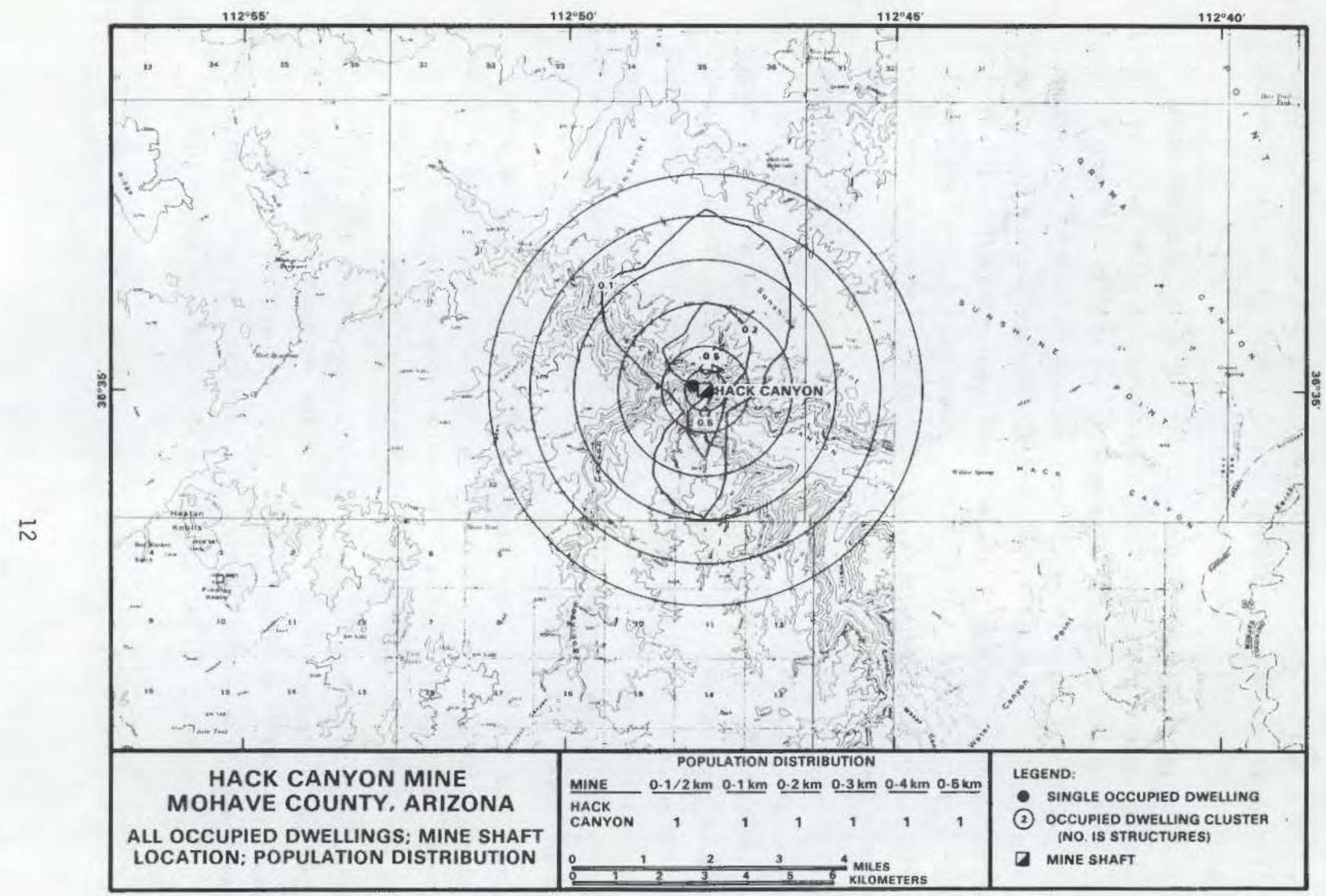

FIGURE 4. Estimated Incremental Radon Concentration Contours, pCi/L, allowing for Plume Rise at Case Study Mine 1 


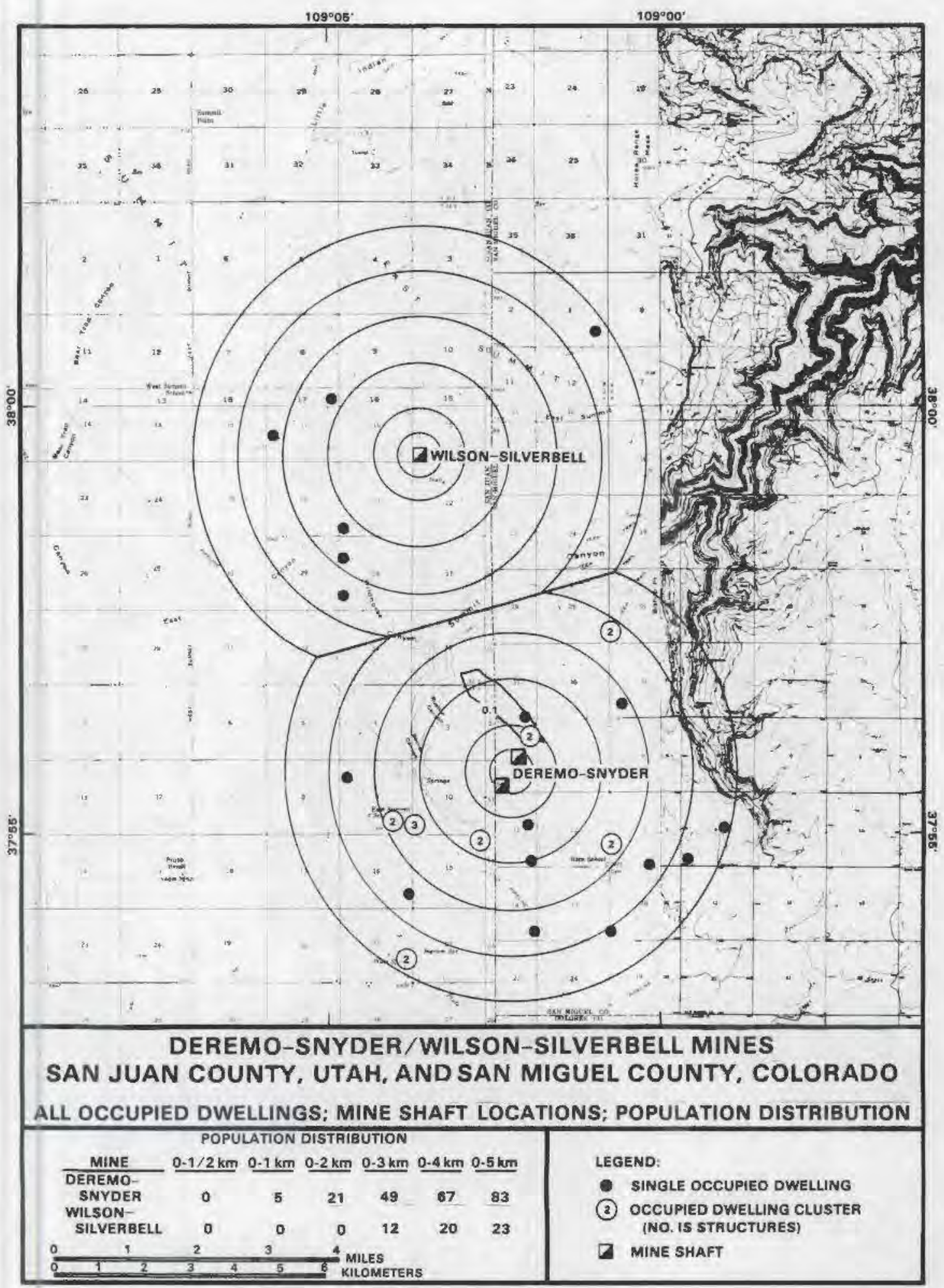

FIGURE 5. Estimated Incremental Radon Concentration Contours, $\mathrm{pCi} / \mathrm{L}$, Allowing for P1 ume Rise at Case Study Mine 2 


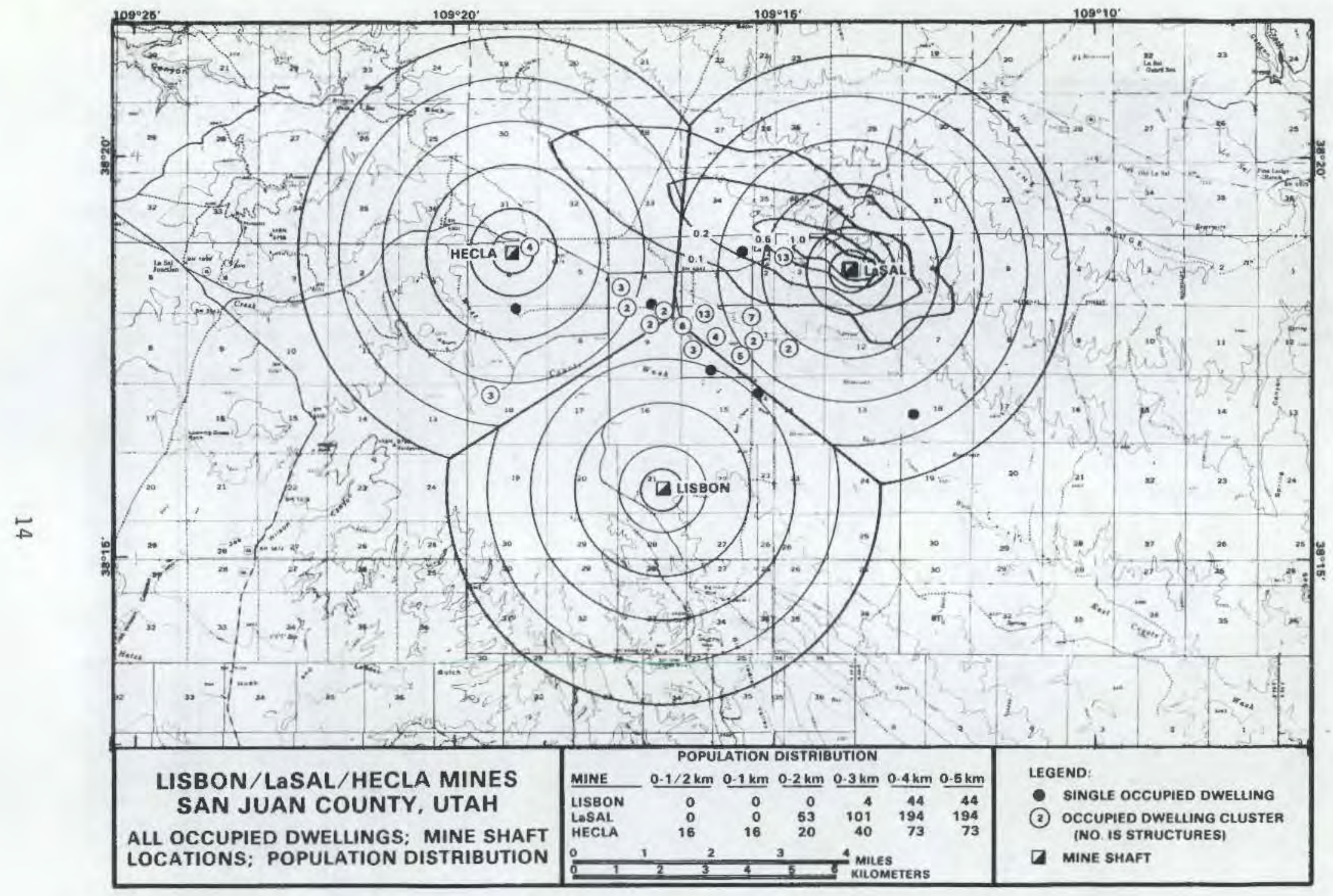

FIGURE 6. Estimated Incremental Radon Concentration Contours, $\mathrm{pCi} / \mathrm{L}$, allowing for Plume Rise at Case Study Mine 3 


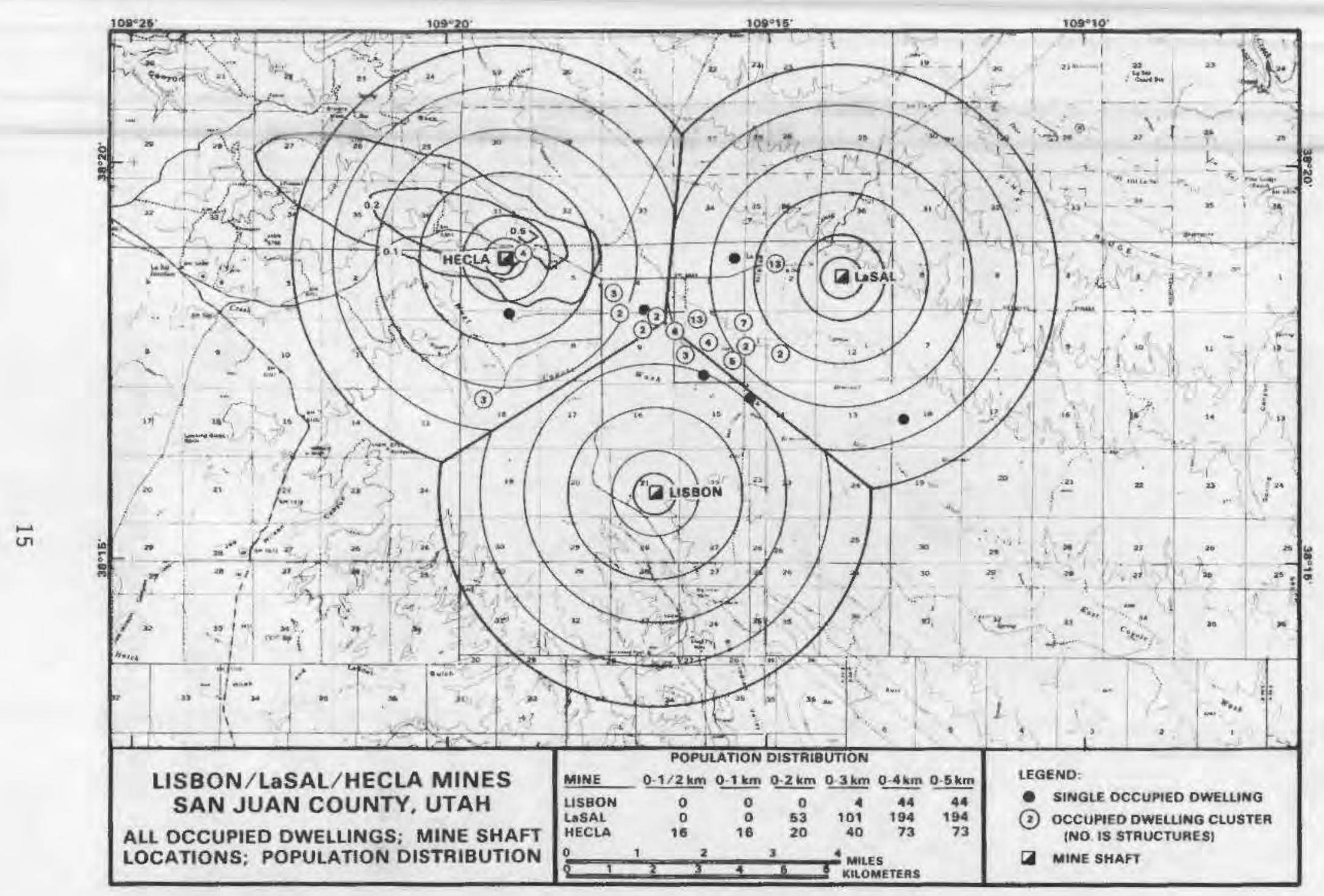

FIGURE 7. Estimated Incremental Radon Concentration Contours, pCi/L, allowing for Plume Rise at Case Study Mine 4 


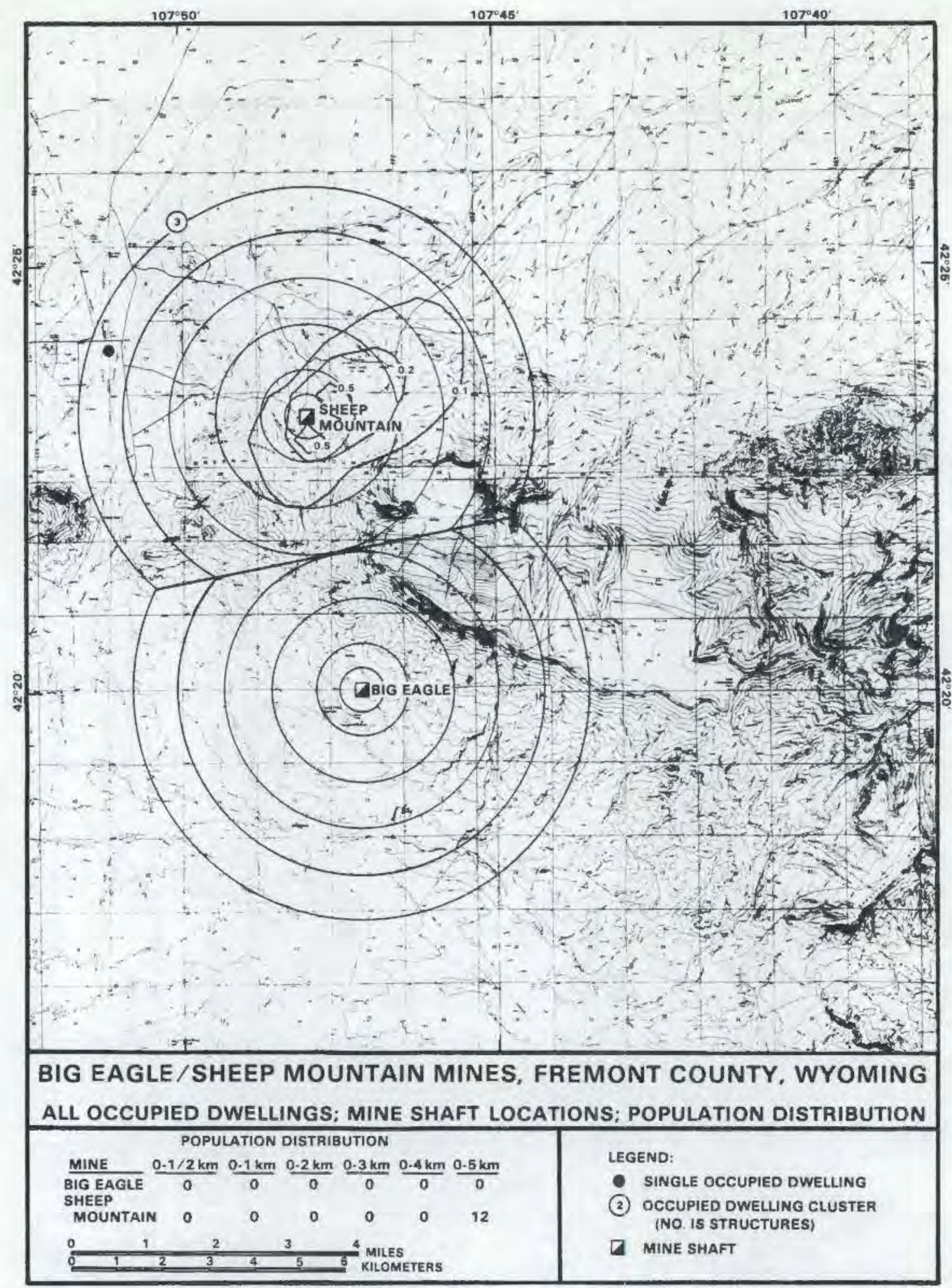

FIGURE 8. Estimated Incremental Radon Concentration Contours, PCi/L, Allowing for Plume Rise at Case Study Mine 5 


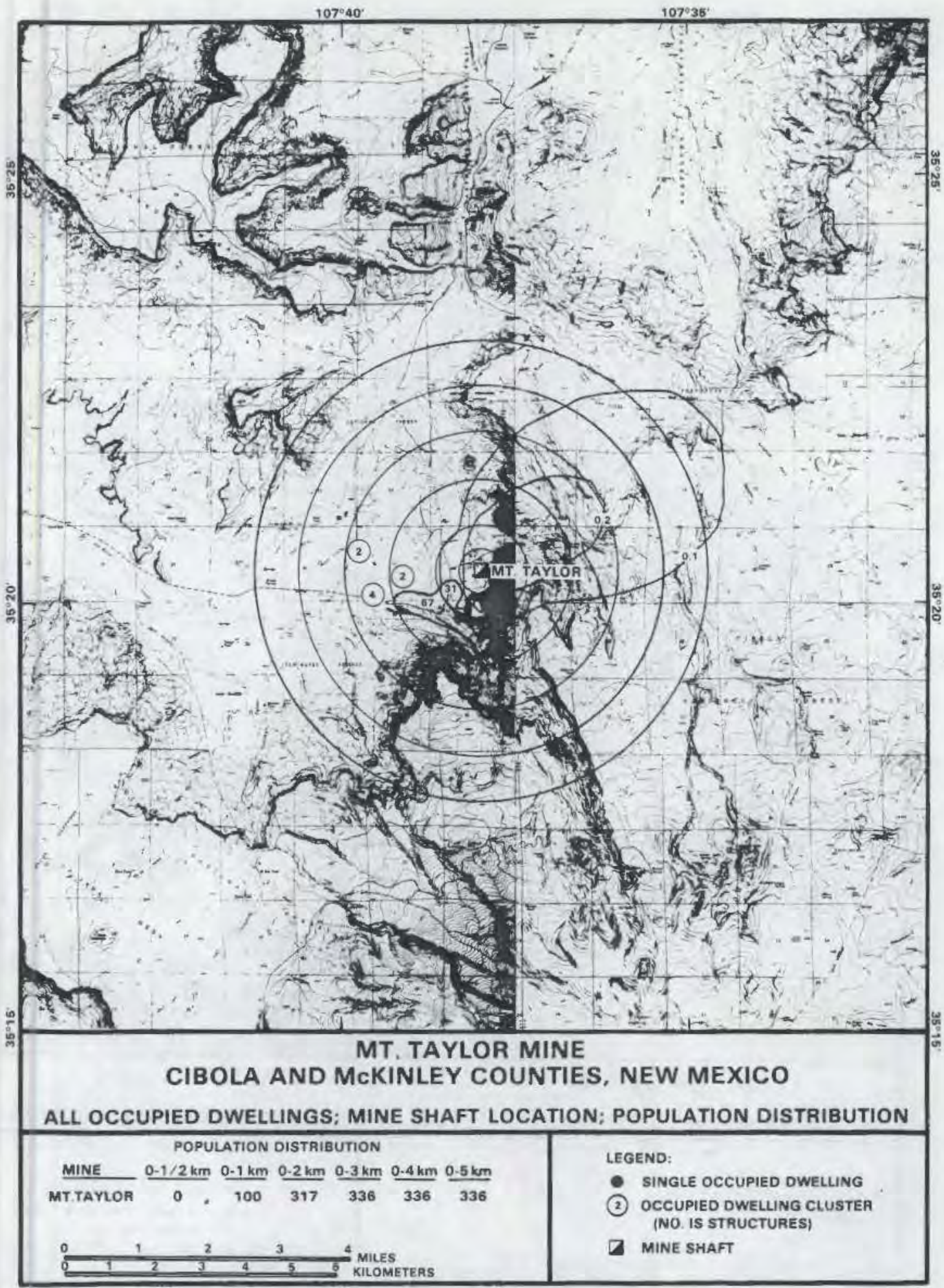

FIGURE 9. Estimated Incremental Radon Concentration Contours, $\mathrm{pCi} / \mathrm{L}$, Allowing for Plume Rise at Case Study Mine 6 


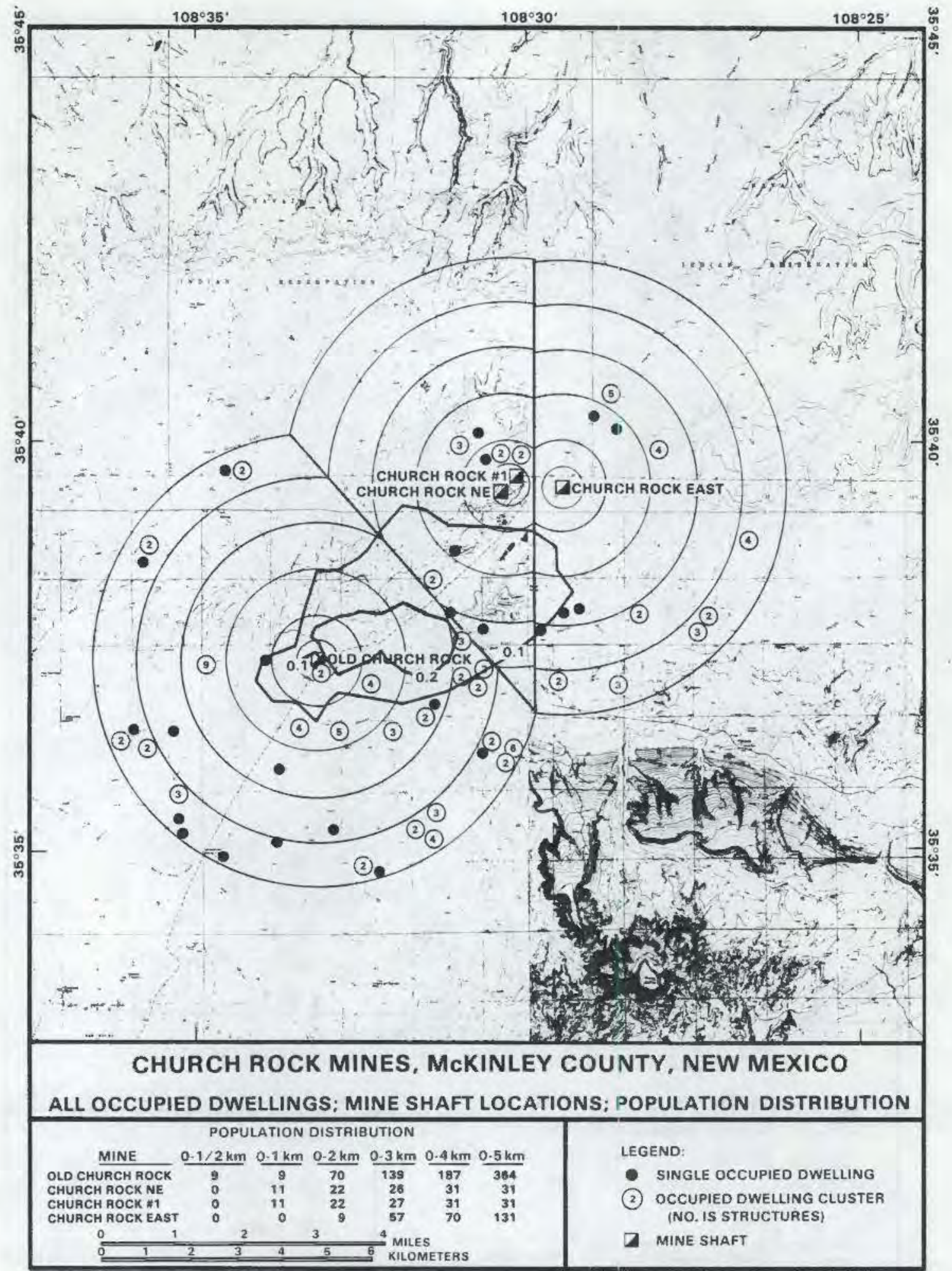

FIGURE 10. Estimated Incremental Radon Concentration Contours, $\mathrm{pCi} / \mathrm{L}$, Allowing for Plume Rise at Case Study Mine 7 


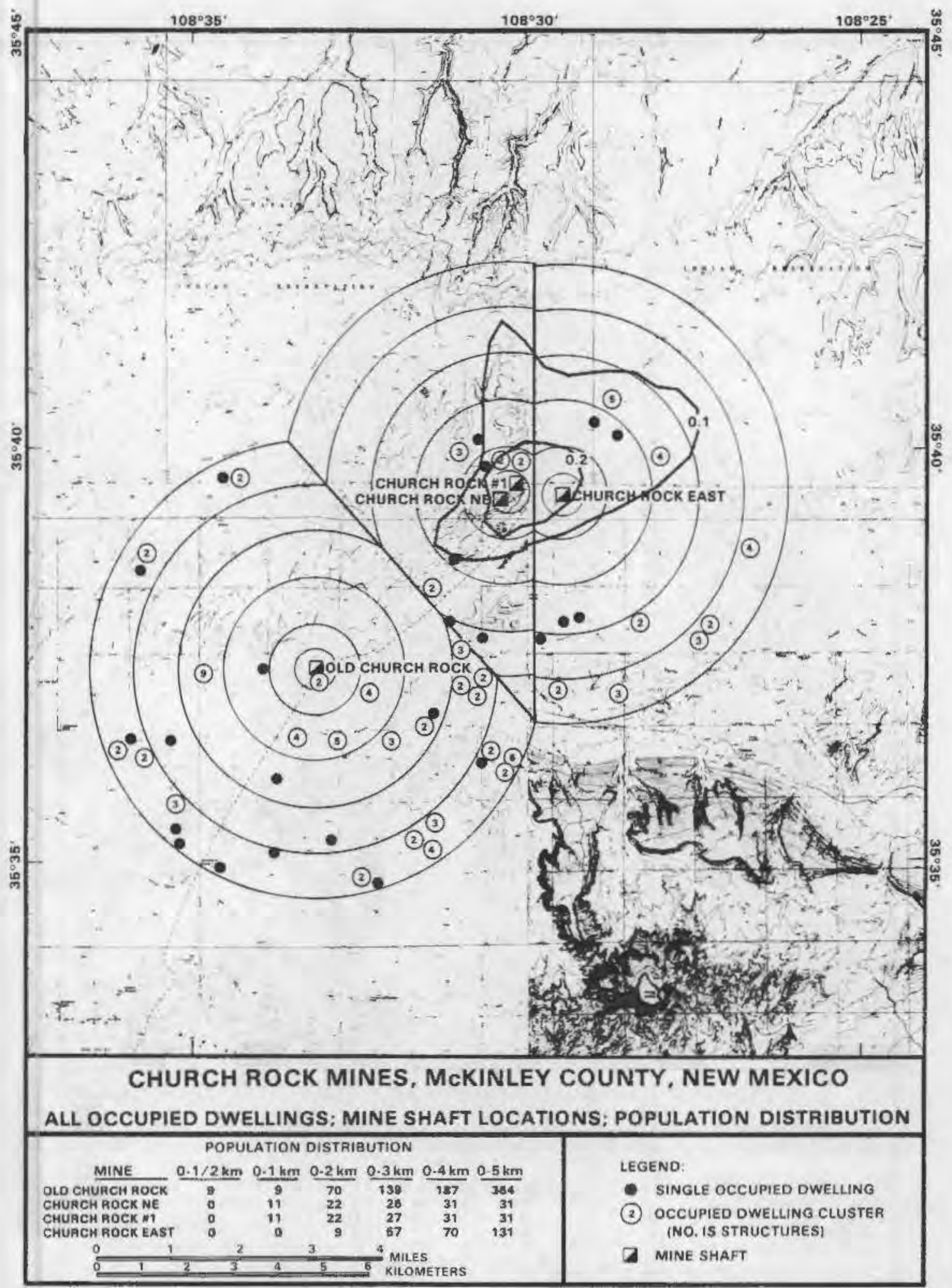

FIGURE 11. Estimated Incremental Radon Concentration Contours Allowing for Plume Rise at Case Study Mine 8 


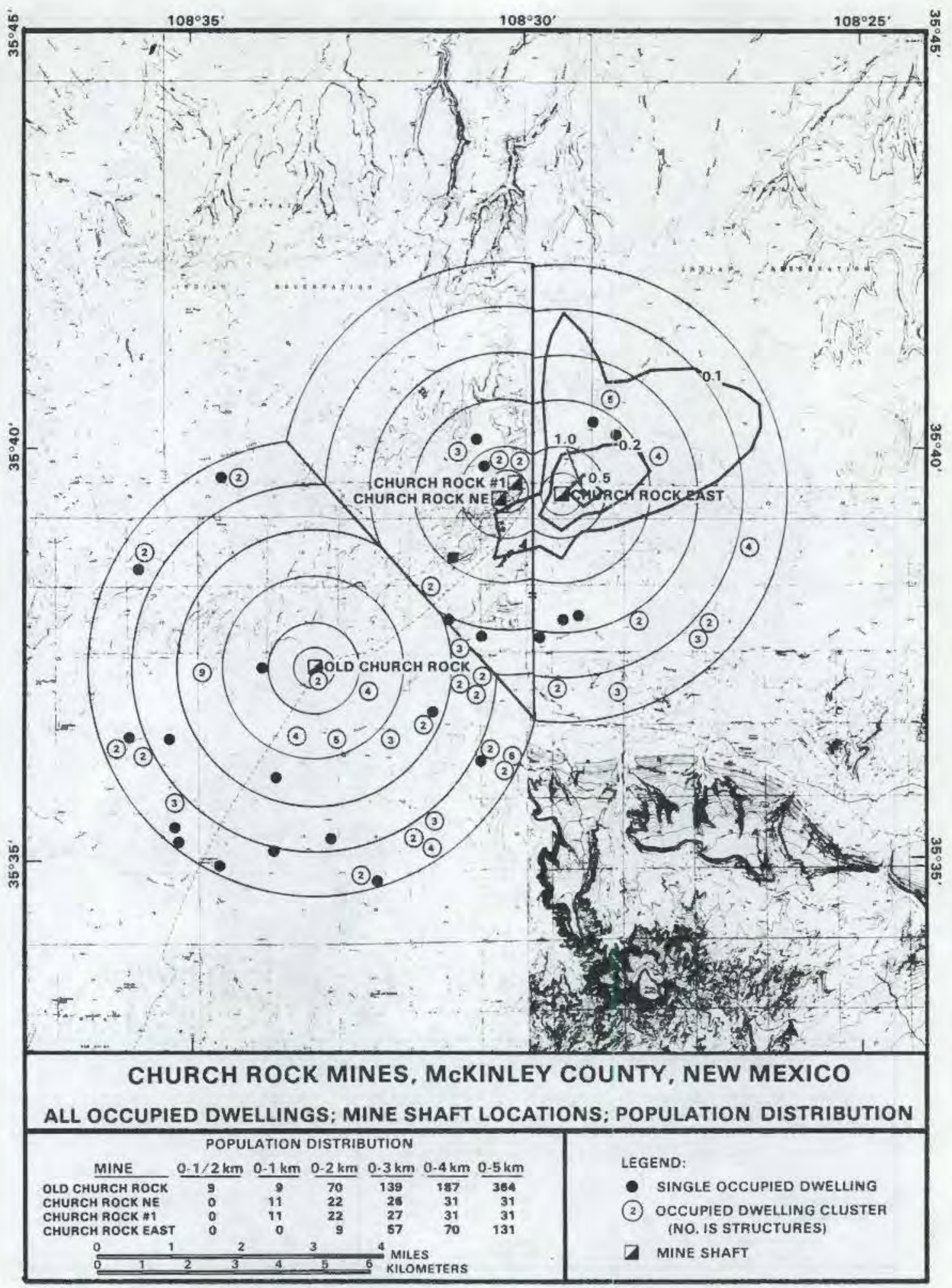

FIGURE 12. Estimated Incremental Radon Concentration Contours, $\mathrm{pCi} / \mathrm{L}$, Allowing for Plume Rise at Case Study Mine 9 


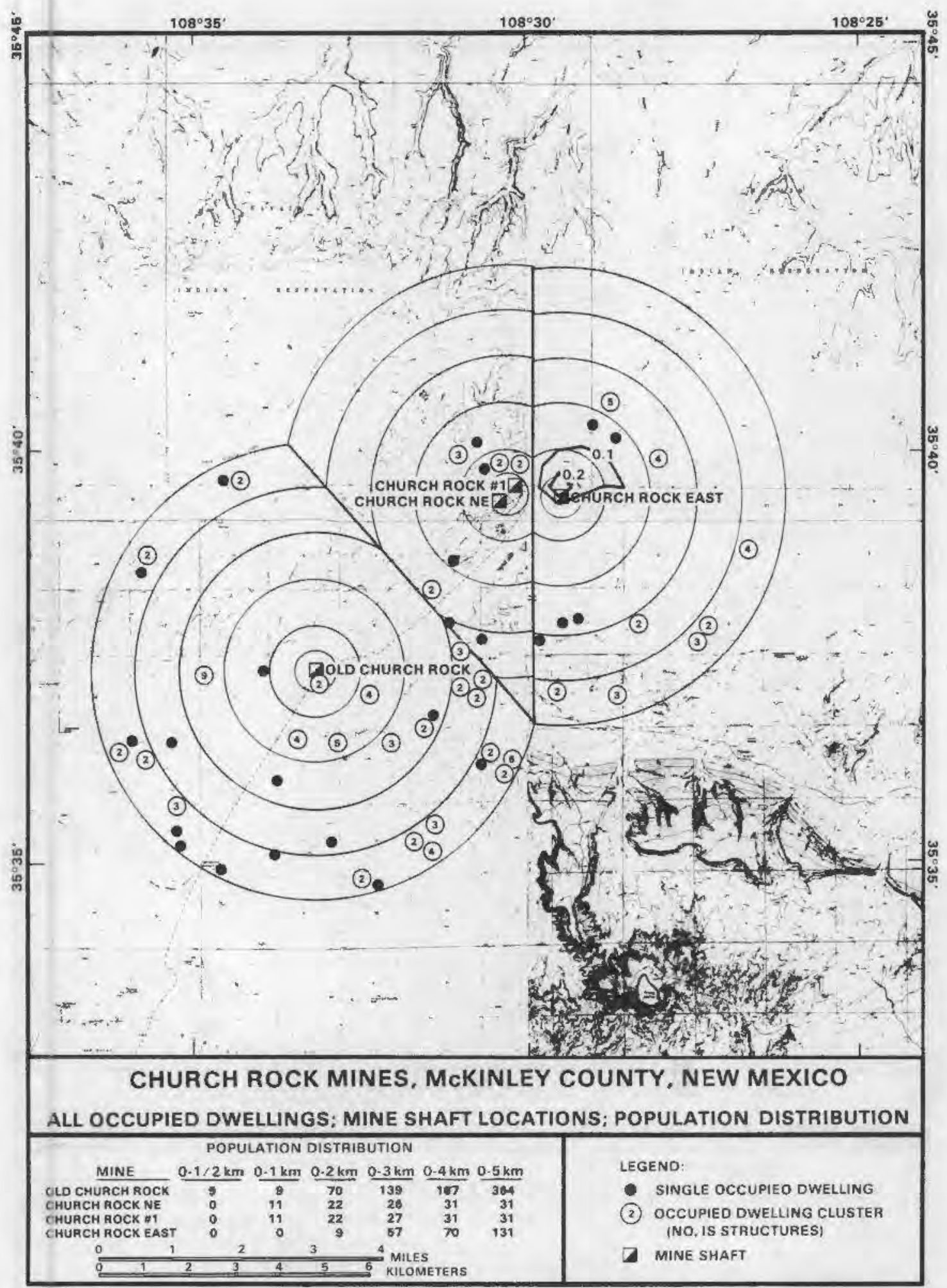

FIGURE 13. Estimated Incremental Radon Concentration Contours, $\mathrm{pCi} / \mathrm{L}$, Allowing for Plume Rise at Case Study Mine 10 


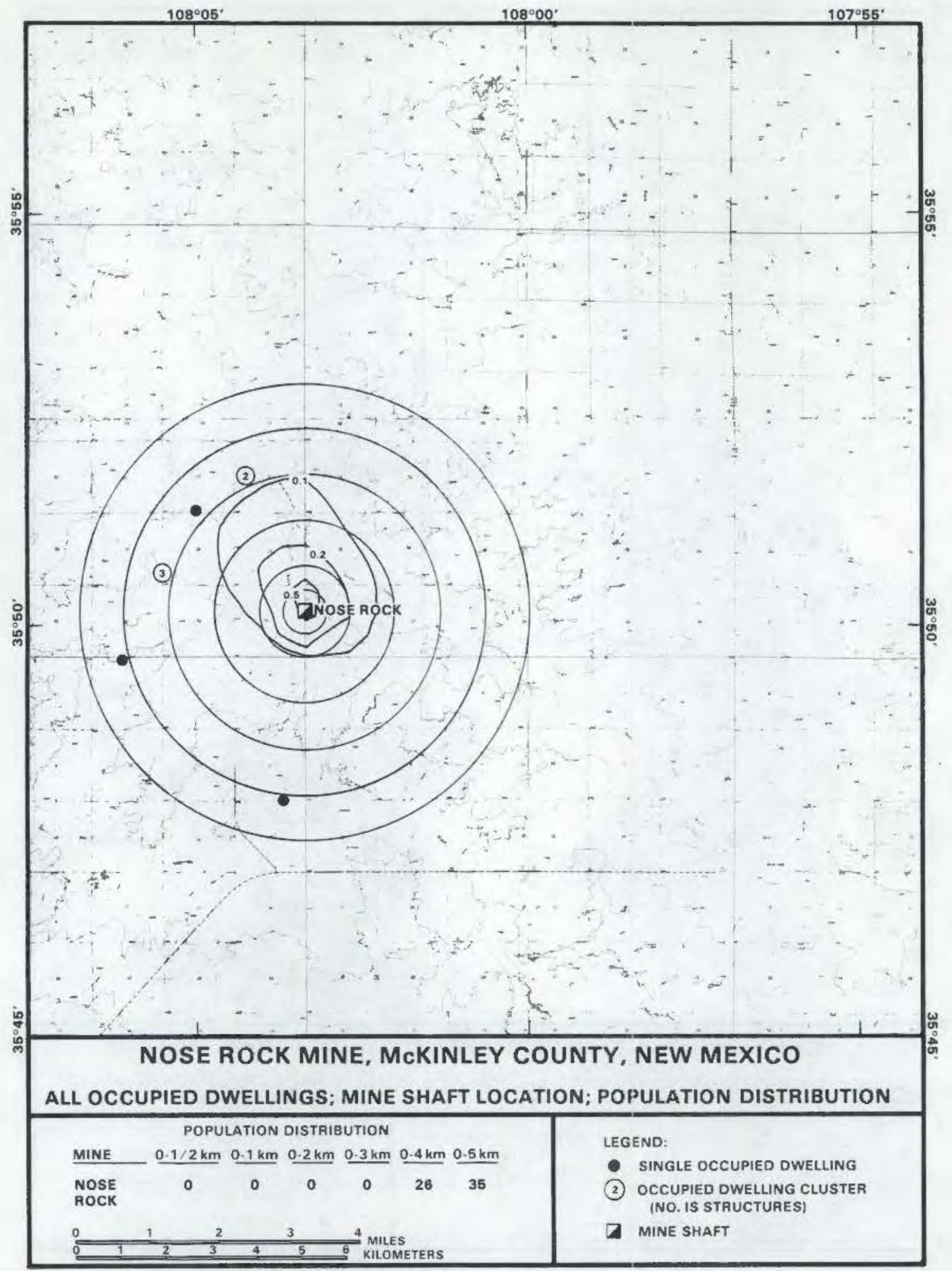

FIGURE 14. Estimated Incremental Radon Concentration Contours, $\mathrm{pCi/L}$, Allowing for Plume Rise at Case Study Mine 13 


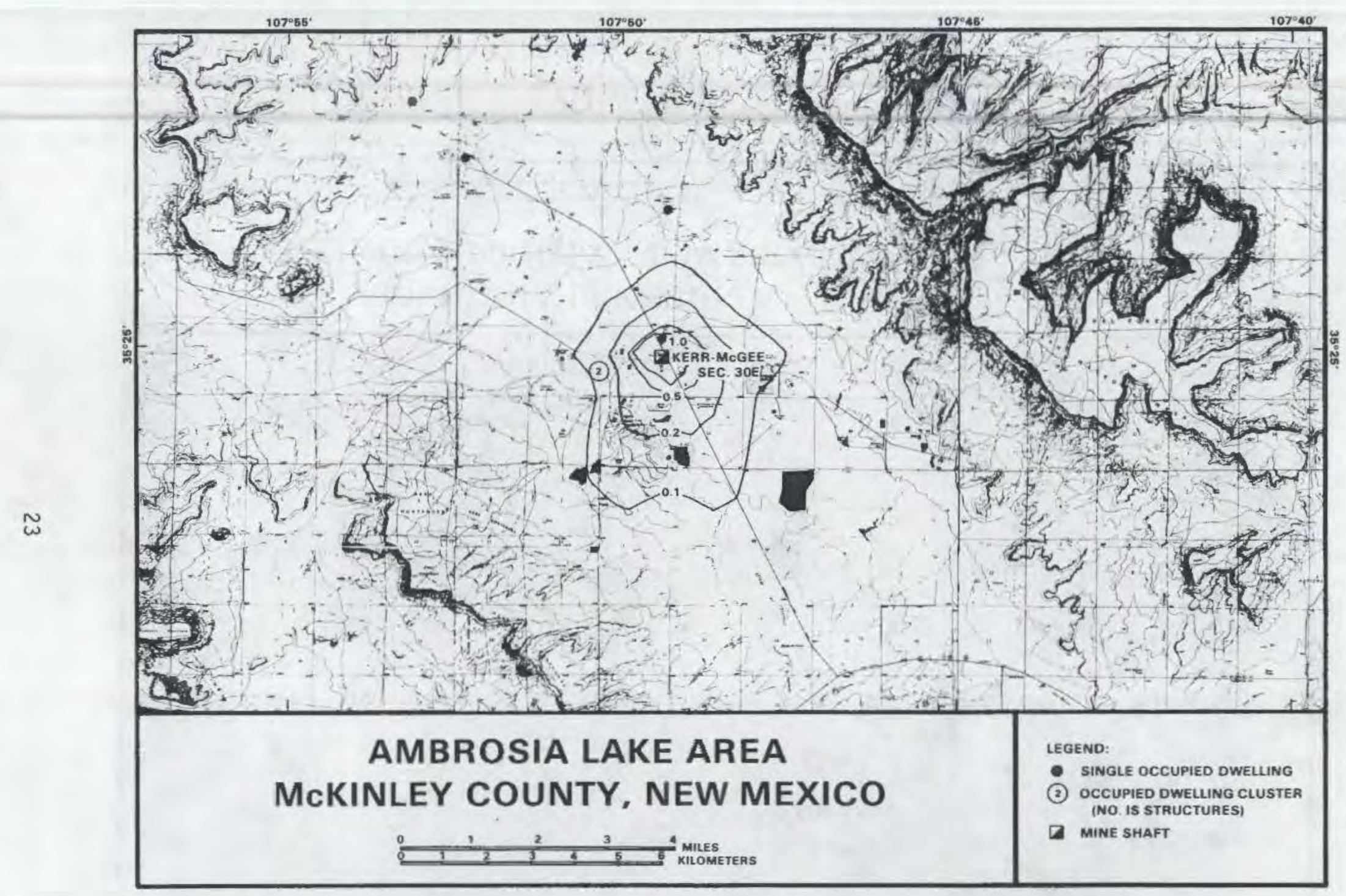

FIGURE 15. Estimated Incremental Radon Concentration Contours, $\mathrm{PCi} / \mathrm{L}$, Allowing for Actual Vent Configurations, $\mathrm{PCi} / \mathrm{L}$, at Case Study Mine 11 


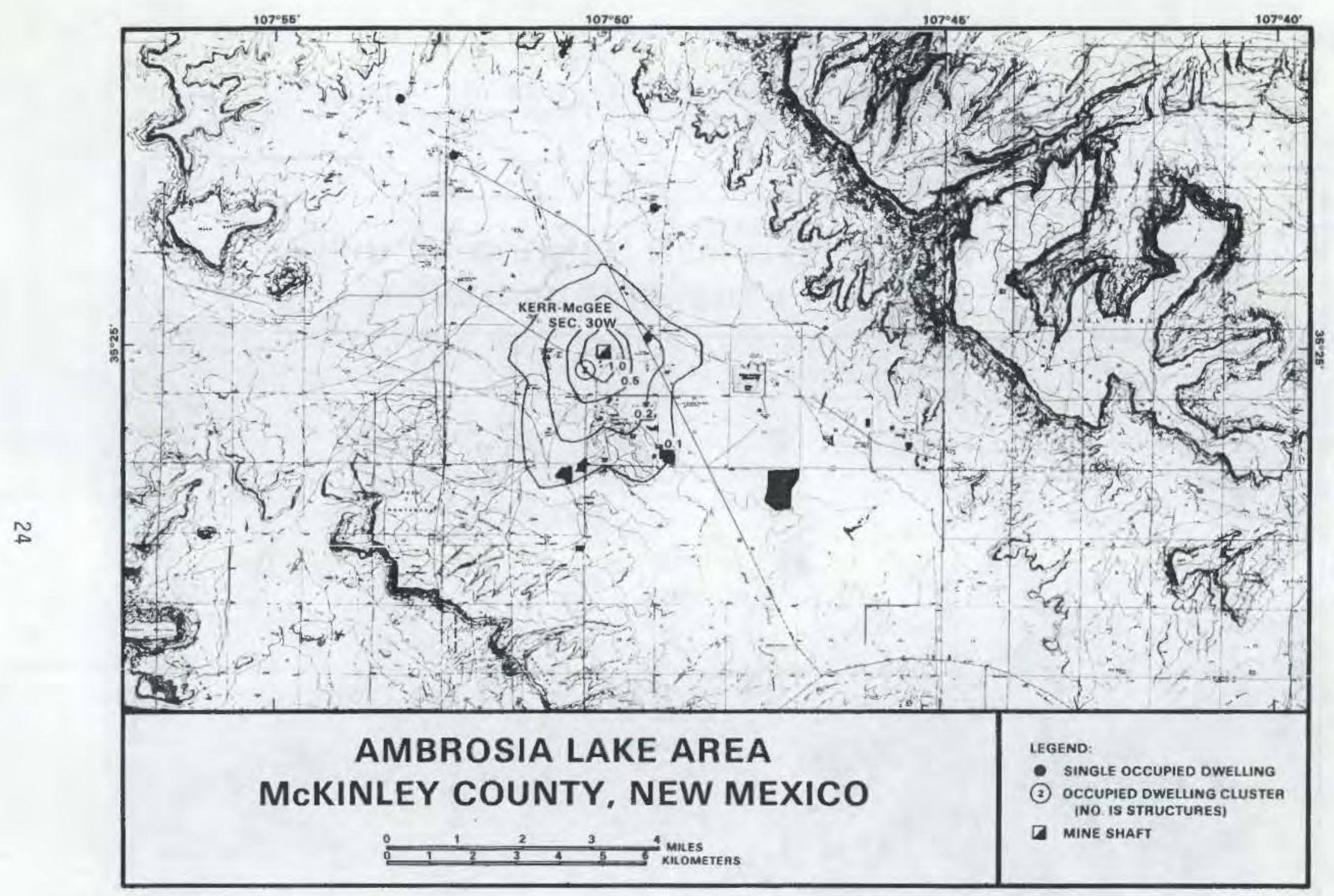

FIGURE 16. Estimated Incremental Radon Concentration Contours, pCi/L, Allowing for Actual Vent Configurations at Case Study Mine 12 


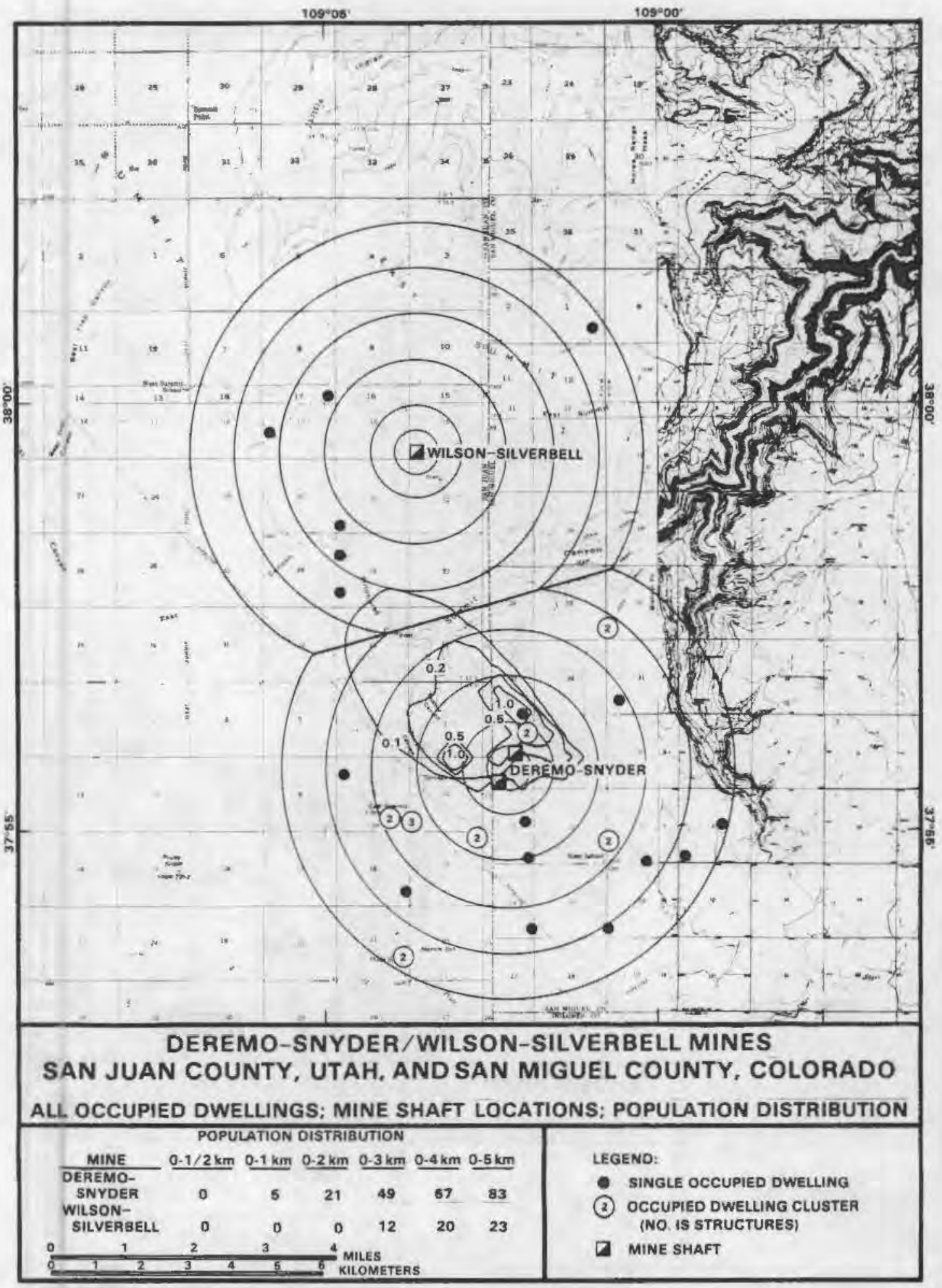

FIGURE 17. Estimated Incremental Radon Concentration Contours, $\mathrm{pCi} / \mathrm{L}$, Based on a No Plume Rise Assumption at Case Study Mine 2 


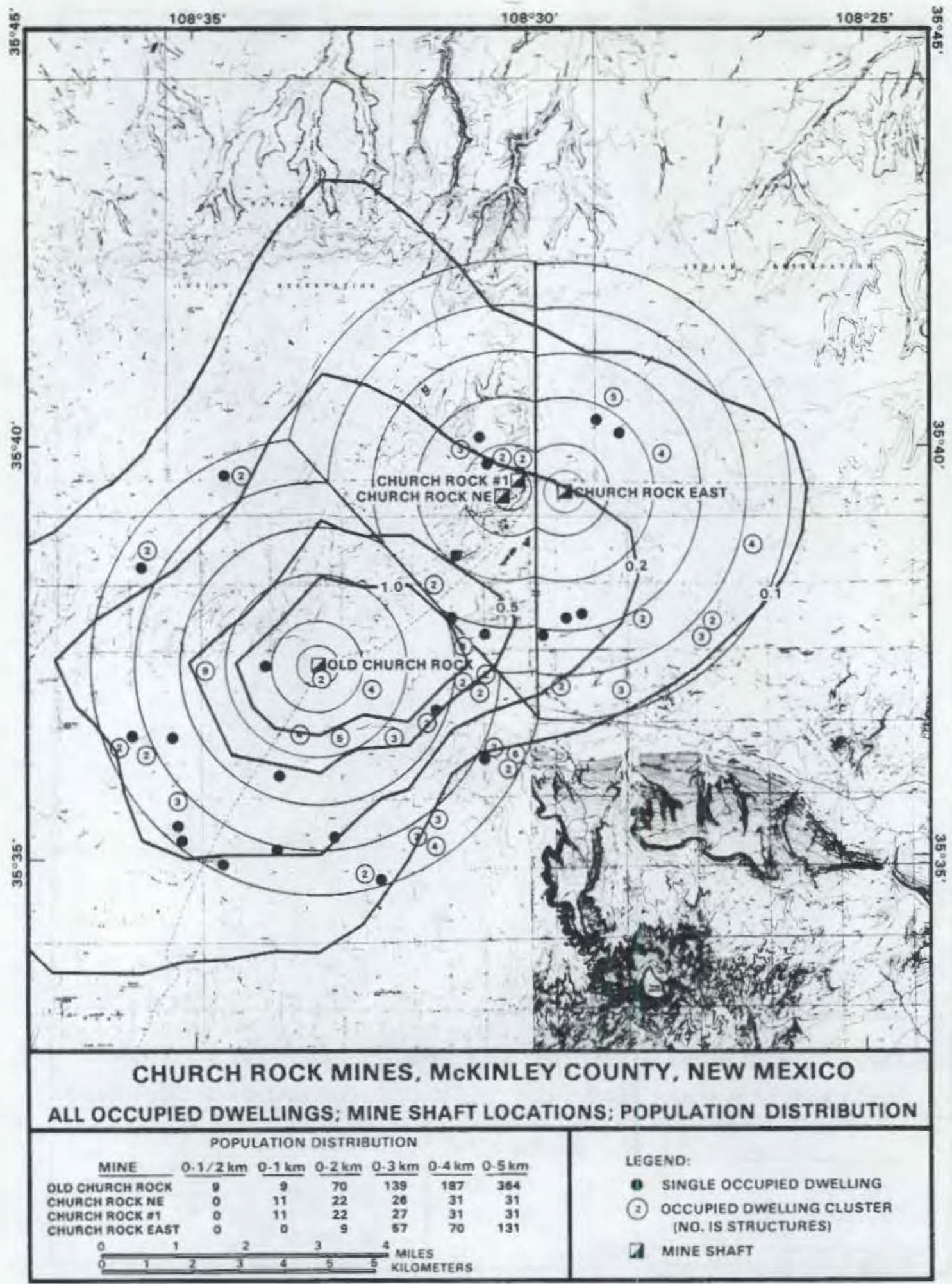

FIGURE 18. Estimated Incremental Radon Concentration Contours, $\mathrm{pCi} / \mathrm{L}$, Based on a No Plume Rise Assumption at Case Study Mine 7 


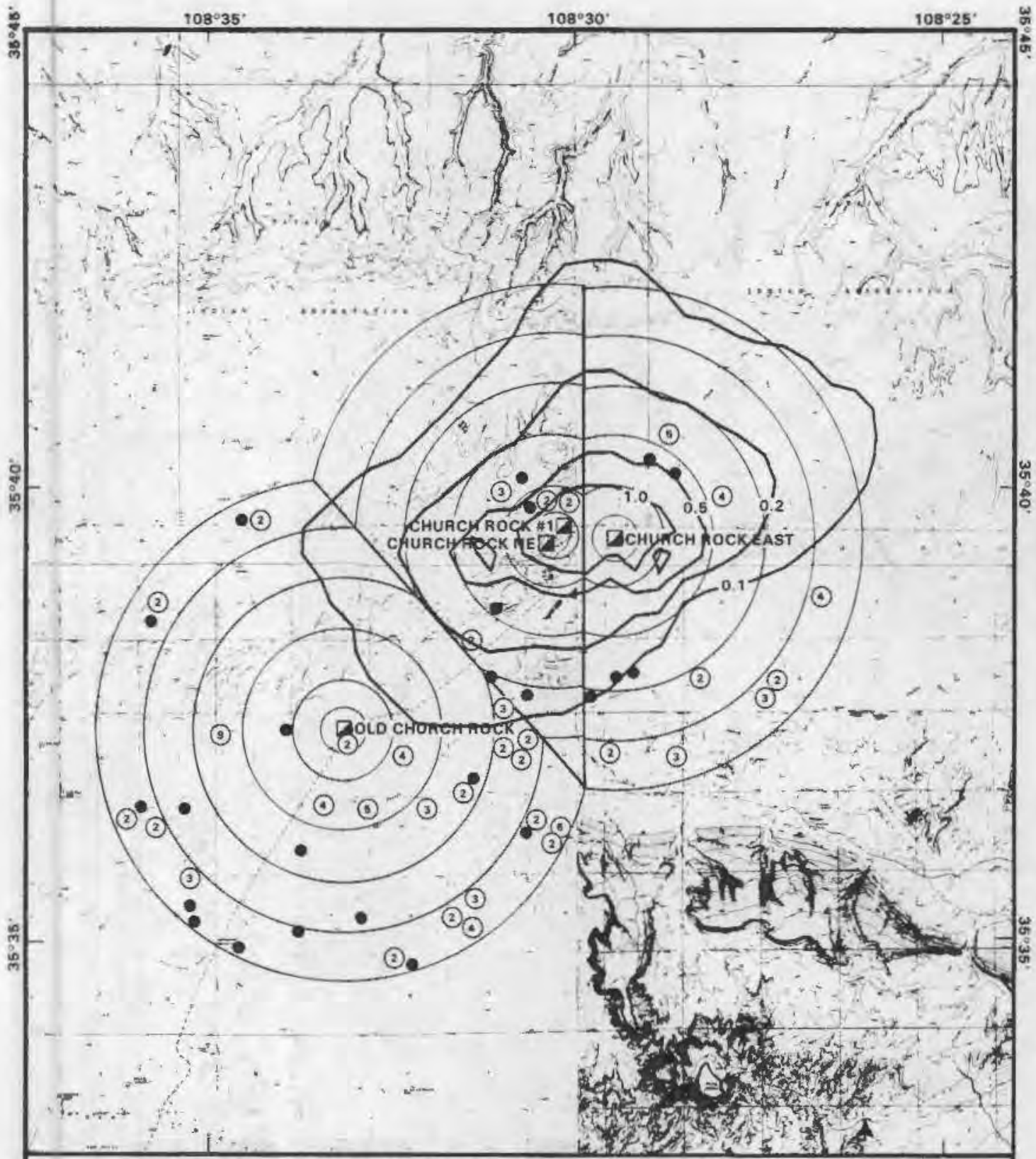

CHURCH ROCK MINES, MCKINLEY COUNTY, NEW MEXICO

ALL OCCUPIED DWELLINGS; MINE SHAFT LOCATIONS; POPULATION DISTRIBUTION

\begin{tabular}{|c|c|c|c|c|c|c|}
\hline & POPU & LATION & DISTAIE & BUTION & & \\
\hline MINE & $0.1 / 2 \mathrm{~km}$ & $0-1 \mathrm{~km}$ & $0.2 \mathrm{~km}$ & $0.3 \mathrm{~km}$ & $0.4 \mathrm{~km}$ & $0.5 \mathrm{~km}$ \\
\hline OSD CHURCH ROCK & 9 & 8 & 70 & 138 & 187 & 364 \\
\hline CHUACH ROCK NE & 0 & 11 & 22 & 26 & 31 & 31 \\
\hline СНUACH АOCK *1 & $\therefore$ & 11 & 22 & 27 & 31 & 31 \\
\hline СНUFCH ROCK EAST & 0 & 0 & $\theta$ & 57 & 70 & 131 \\
\hline
\end{tabular}

LEGEND:

- single occupied dwelling

(2) OCCUPIED DWELLING CLUSTER (NO. IS STRUCTURES)

D MINE SHAFT

FIGURE 19. Estimated Incremental Radon Concentration Contours, pCi/L, Based on a No Plume Rise Assumption at Case Study Mine 10 


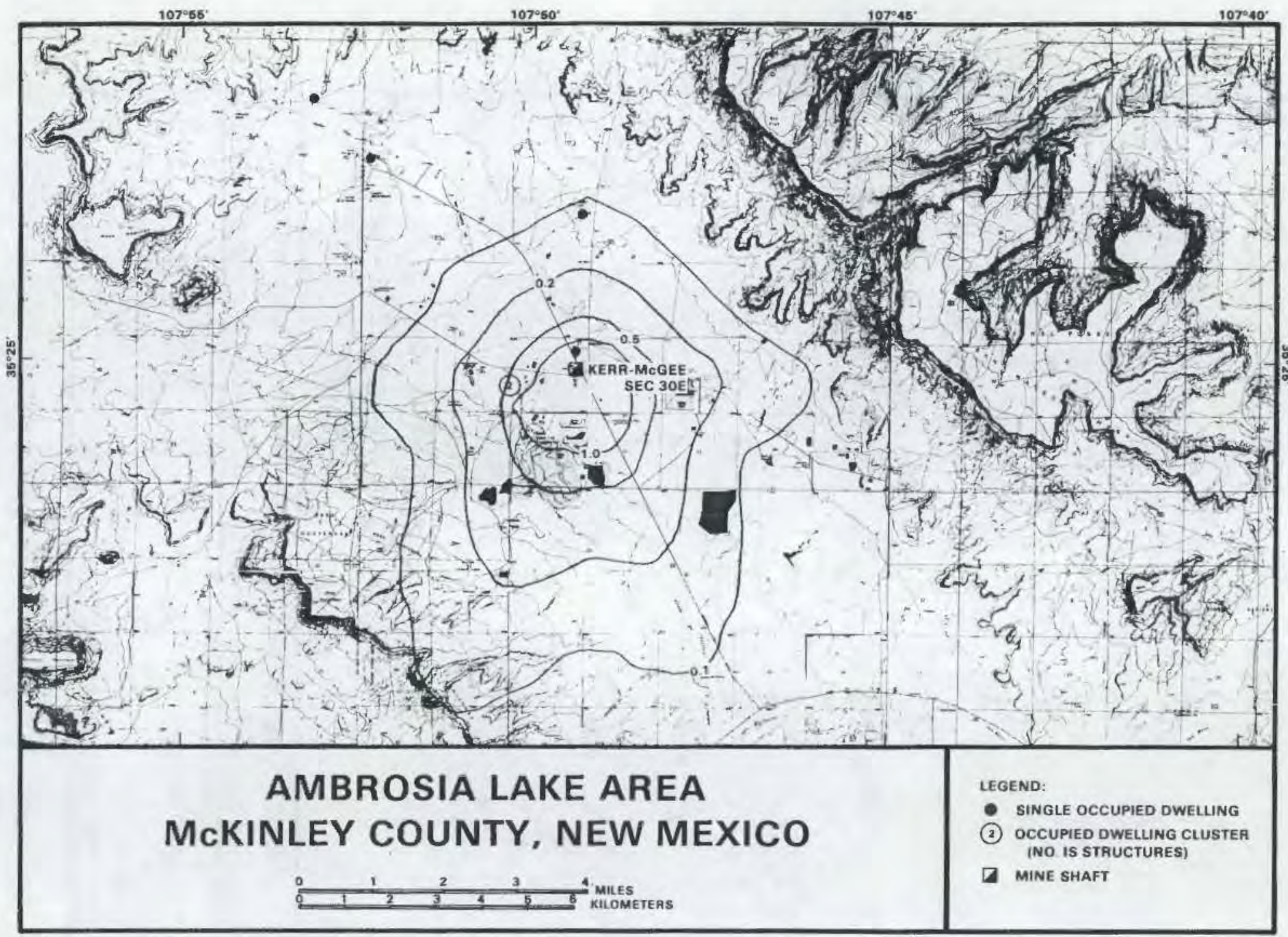

FIGURE 20. Estimated Incremental Radon Concentration Contours, $\mathrm{pCi} / \mathrm{L}$, Based on a No Plume Rise Assumption at Case Study Mine 11 


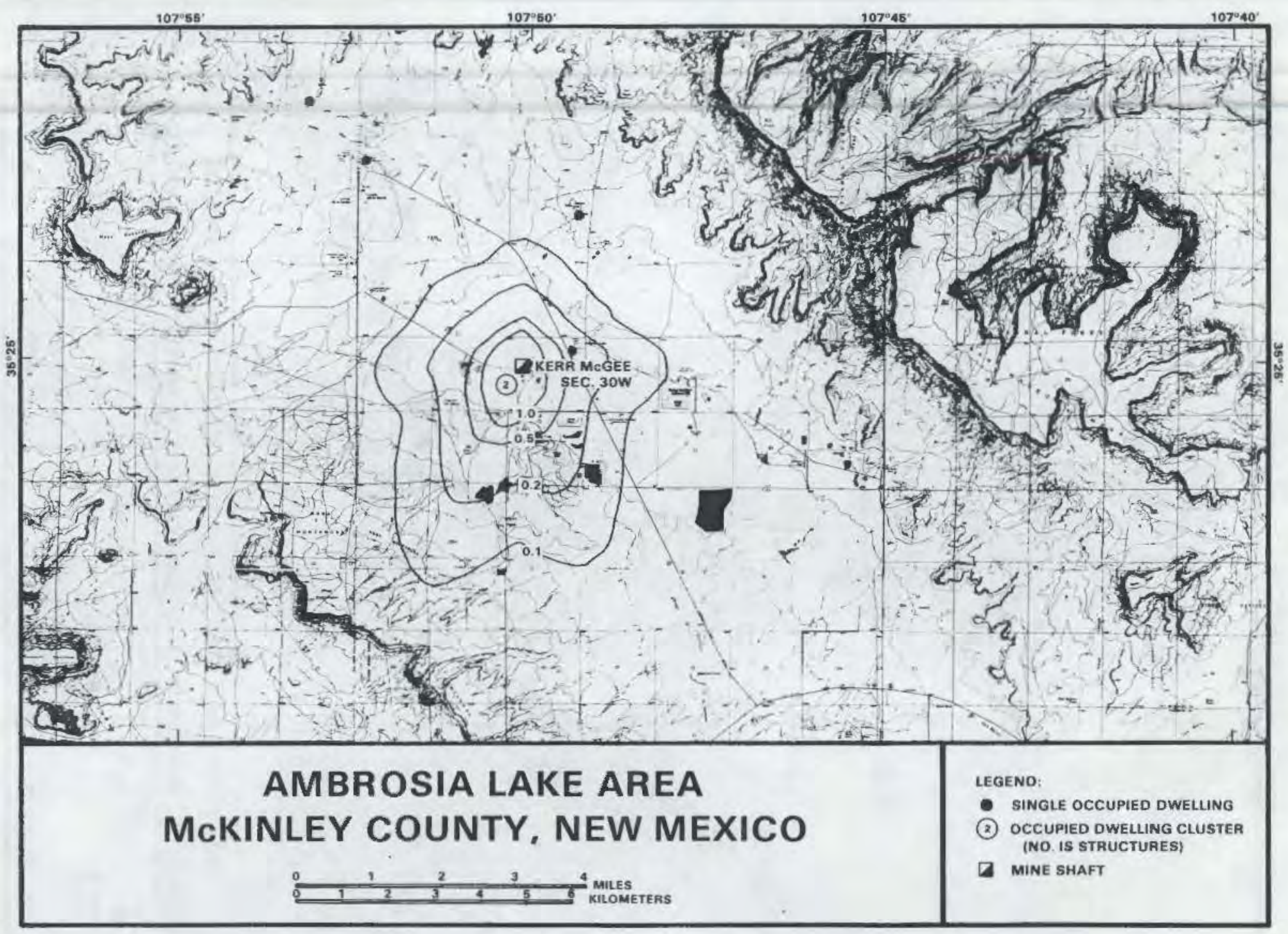

FIGURE 21. Estimated Incremental Radon Concentration Contours, $\mathrm{pCi} / \mathrm{L}$, Based on a No Plume Rise Assumption at Case Study Mine 12 


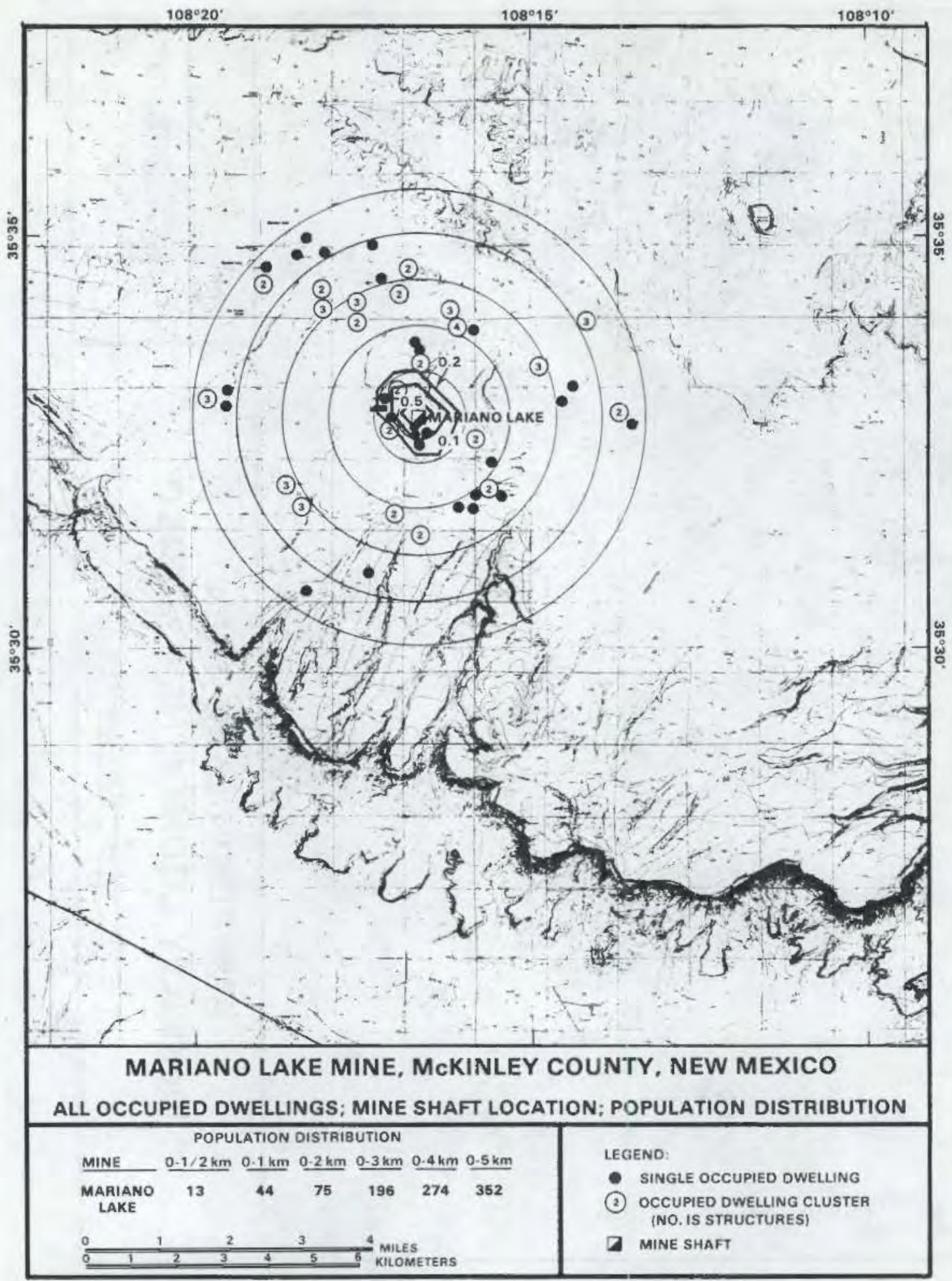

FIGURE 22. Estimated Incremental Radon Concentration Contours, $\mathrm{PCi} / \mathrm{L}$, Based on a No Plume Rise Assumption at Case Study Mine 14 
oriented vertically without changing the exit sizes and velocities. As with the case study computations done previously, the best available meteorological data were used for each mine.

The average concentrations were computed as a function of distance in two ways. First, the average concentration values at each distance were computed for each of the six mines. Overall average concentrations as a function of distance were then computed by averaging the six sets of mine values. This result is the 'mine average' curve in Figure 23. Second, the 'vent average' curve is based on giving equal weight to each of the vents. This average of the concentrations from the 41 vents has slightly lower values than the mine average. These curves provide an estimate of the dependence of radon concentration as function of downwind distance based on these mines and their local characteristics. Based on this figure, the screening formula developed by EPA in 1983 (EPA 1983) appears to give a reasonable prediction of the average variation of concentration with distance. 


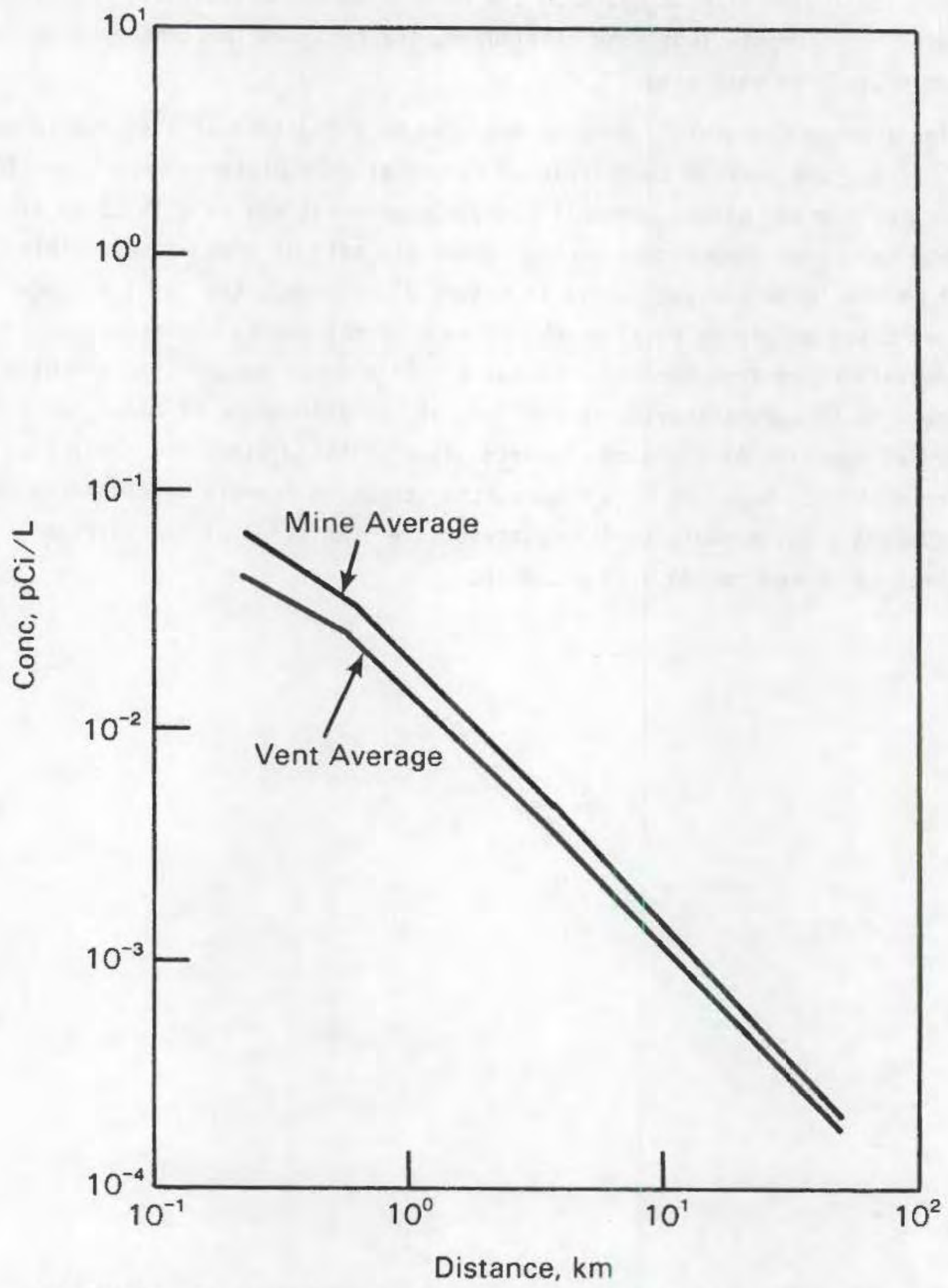

FIGURE 23. Average Incremental Radon Concentrations, pCi/L, Downwind of the Six Mines with Measured Release Characteristics Based on a Generic Release of 11,000 Ci/yr for Each Mine 


\section{MULTIPLE MINE COMPUTATION}

In practice, several mines often occur in the same region. The radon concentrations computed in the preceding sections for individual mines may overlap to produce greater values. The question of cumulative mine impacts was addressed by modeling the combined concentrations in a region with intensive uranium mining.

Ambrosia Lake was the intensive mining area selected for a multiple mine computation. A total of over 100 mine vents are used by the underground uranium mines in this region. Case study mines 11 and 12 are located in this area.

Vent locations for mines at Ambrosia Lake identified by Droppo and Glissmeyer (1981) are given in Figure 24. Emission rates for these vents are given in Table 3 based on earlier measurement programs. These reported emission rates are maximum values from two sets of measurements.

Ground level releases with no plume rise for multiple mines at Ambrosia Lake were computed previously using a different climatological dispersion model (Droppo and Glissmeyer 1981). These were rerun using ISCLT with the same input parameters as the earlier study. The results were equivalent. Predicted contours were the same both in shape and location. This closeness of results is to be expected because the same dispersion relationships and coefficients are used in the two models. Although a different meteorological data set is used in the computations reported in this study, the magnitudes and contour shapes for the no-plume-rise case are quite close to those reported in 1981.

The horizontal and vertical configurations of the vents were known for the two case study mines located in this region. For these two mines, 5 of the 17 vents were horizontal. It is reasonable to expect that other vents in the area may be horizontal. The lack of specific vent orientation information was addressed by considering the extremes of all vertical vents with plume rise or all vents without any plume rise (horizontal). Then an intermediate case with plume rise for five horizontal vents at the two case study mines, 11 and 12 , was run to see how significantly horizontal vents influence the computed radon patterns. 


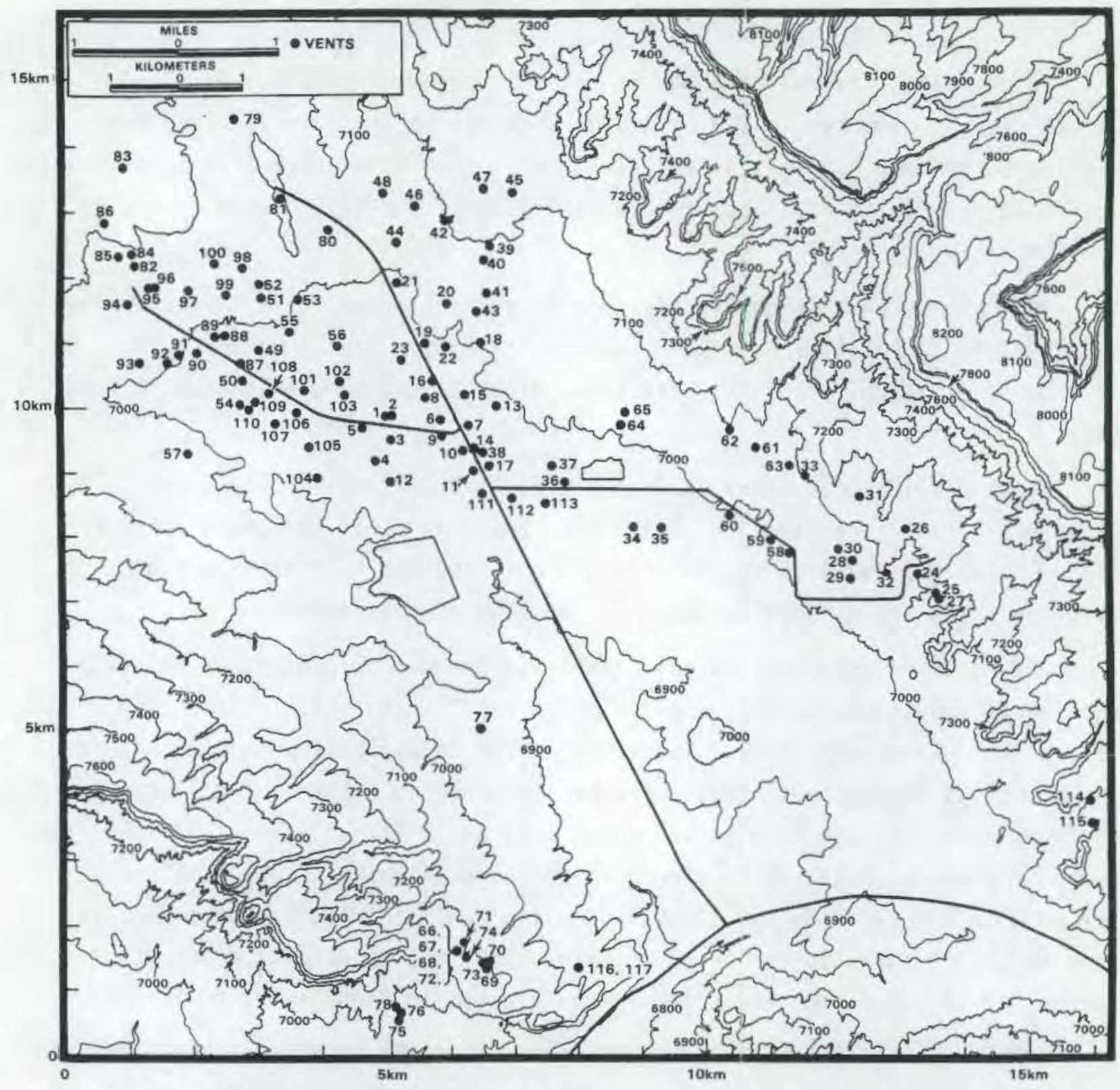

FIGURE 24. Detailed Map of Selected Multiple Mine Area Showing Vent Locations (Droppo and Glissmeyer 1981) 
TABLE 3. Source Terms for Multiple Mine Computation (Droppo and Gl issmeyer 1981)

\begin{tabular}{|c|c|c|c|c|c|c|c|c|}
\hline $\begin{array}{l}\text { Emis- } \\
\text { sion } \\
\text { Rate } \\
\text { Rank }\end{array}$ & $\begin{array}{l}\text { Vent } \\
\text { Num- } \\
\text { ber } \\
\text { Fig. } \\
24\end{array}$ & $\begin{array}{l}\text { Radon } \\
\text { Emission } \\
\text { Rate } \\
(\mathrm{Ci} / \mathrm{yr})\end{array}$ & $\begin{array}{l}\text { Emis- } \\
\text { sion } \\
\text { Rate } \\
\text { Rank }\end{array}$ & $\begin{array}{l}\text { Vent } \\
\text { Num- } \\
\text { ber } \\
\text { Fig. } \\
24\end{array}$ & $\begin{array}{l}\text { Radon } \\
\text { Emission } \\
\text { Rate } \\
(\mathrm{Ci} / \mathrm{yr})\end{array}$ & $\begin{array}{l}\text { Emis- } \\
\text { sion } \\
\text { Rate } \\
\text { Rank }\end{array}$ & $\begin{array}{c}\text { Vent } \\
\text { Num- } \\
\text { ber } \\
\text { Fig. } \\
24\end{array}$ & $\begin{array}{l}\text { Radon } \\
\text { Emission } \\
\text { Rate } \\
(\mathrm{Ci} / \mathrm{yr})\end{array}$ \\
\hline$-\infty$ & $\cdots$ & $+-\infty$ & $m$ & $-\cdot-$ & $\ldots$ & $\ldots$ & $+\cdots$ & $\ldots$ \\
\hline 1 & 94 & 8310 & 41 & 13 & 810 & 81 & 61 & 280 \\
\hline 2 & 99 & 5670 & 42 & 38 & 810 & 82 & 100 & 270 \\
\hline 3 & 110 & 5310 & 43 & 89 & 790 & 83 & 34 & 250 \\
\hline 4 & 82 & 5170 & 44 & 5 & 770 & 84 & 71 & 240 \\
\hline 5 & 105 & 4900 & 45 & 92 & 760 & 85 & 18 & 220 \\
\hline 6 & 87 & 4570 & 46 & 59 & 750 & 86 & 112 & 220 \\
\hline 7 & 95 & 4540 & 47 & 48 & 720 & 87 & 12 & 210 \\
\hline 8 & 25 & 3990 & 48 & 115 & 720 & 88 & 55 & 210 \\
\hline 9 & 54 & 3180 & 49 & 11 & 660 & 89 & 74 & 210 \\
\hline 10 & 52 & 2770 & 50 & 16 & 660 & 90 & 102 & 210 \\
\hline 11 & 51 & 2510 & 51 & 24 & 650 & 91 & 26 & 200 \\
\hline 12 & 53 & 2490 & 52 & 45 & 650 & 92 & 47 & 200 \\
\hline 13 & 58 & 2330 & 53 & 65 & 643 & 93 & 69 & 200 \\
\hline 14 & 27 & 2160 & 54 & 63 & 620 & 94 & 37 & 190 \\
\hline 15 & 79 & 2100 & 55 & 101 & 620 & 95 & 67 & 180 \\
\hline 16 & 49 & 2050 & 56 & 17 & 600 & 96 & 19 & 170 \\
\hline 17 & 2 & 1950 & 57 & 96 & 580 & 97 & 70 & 170 \\
\hline 18 & 29 & 1840 & 58 & 107 & 580 & 98 & 33 & 160 \\
\hline 19 & 40 & 1730 & 59 & .98 & 570 & 99 & 109 & 160 \\
\hline 20 & 9 & 1720 & 60 & 35 & 530 & 100 & 20 & 150 \\
\hline 21 & 88 & 1690 & 61 & 81 & 530 & 101 & 66 & 140 \\
\hline 22 & 44 & 1680 & 62 & 60 & 500 & 102 & 68 & 130 \\
\hline 23 & 97 & 1560 & 63 & 77 & 500 & 103 & 23 & 100 \\
\hline 24 & 15 & 1500 & 64 & 116 & 500 & 104 & 90 & 99 \\
\hline 25 & 8 & 1410 & 65 & 117 & 500 & 105 & 57 & 96 \\
\hline 26 & 113 & 1400 & 66 & 80 & 460 & 106 & 85 & 88 \\
\hline 27 & 43 & 1320 & 67 & 50 & 450 & 107 & 78 & 87 \\
\hline 28 & 21 & 1290 & 68 & 7 & 430 & 108 & 39 & 72 \\
\hline 29 & 56 & 1260 & 69 & 91 & 420 & 119 & 31 & 54 \\
\hline 30 & 1 & 1250 & 70 & 103 & 410 & 110 & 75 & 52 \\
\hline 31 & 4 & 1230 & 71 & 46 & 380 & 111 & 76 & 47 \\
\hline 32 & 108 & 1230 & 72 & 22 & 350 & 112 & 83 & 40 \\
\hline 33 & 30 & 1210 & 73 & 36 & 350 & 113 & 72 & 37 \\
\hline 34 & 86 & 1180 & 74 & 14 & 340 & 114 & 93 & 10 \\
\hline 35 & 62 & 1160 & 75 & 73 & 340 & & & \\
\hline 36 & 28 & 1070 & 76 & 6 & 330 & & & \\
\hline 37 & 42 & 1060 & 77 & 114 & 330 & & & \\
\hline 38 & 106 & 940 & 78 & 64 & 319 & & & \\
\hline 39 & 111 & 890 & 79 & 32 & 300 & & & \\
\hline 40 & 104 & 880 & 80 & 10 & 290 & & & \\
\hline
\end{tabular}


The radon concentrations from multiple uranium mines in the Ambrosia Lake region modeled for ground level release without plume rise are given in Figure 25, and those concentrations for all vertical vents with plume rise in Figure 26. The ground level release computation assumed a release height of $1 \mathrm{~m}$ and no plume rise. The computations with plume rise used the actual release characteristics for 17 vents (mine 11 and mine 12). For all other vents, the generic model mine vent characteristics are used.

The combination of mines with actual vent configuration (mines 11 and 12) and mines with plume rise is shown in Figure 27. This involves 5 horizontal vents modeled as area sources. Comparison with Figure 26 shows the influence of the known horizontal vents at case study mines 11 and 12 . Similar increases in concentration are to be expected for any additional horizontal vents that may exist in this region. Figure 25 provides an upper 1 imit for what these computed concentrations could approach. 


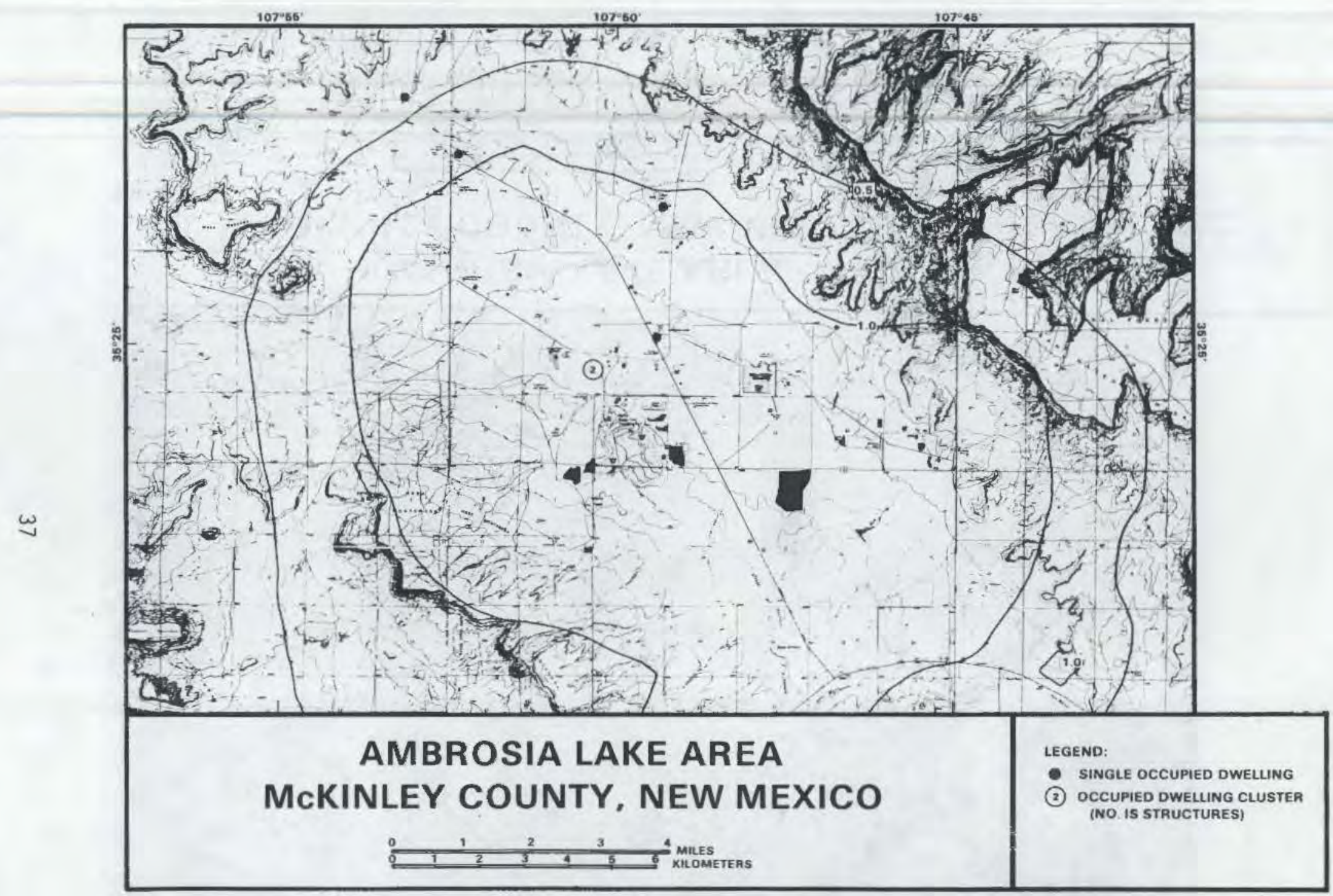

FIGURE 25. Estimated Incremental Radon Concentration Contours, pCi/L, Based on Multiple Mine Emissions Using a No Plume Rise Assumption 


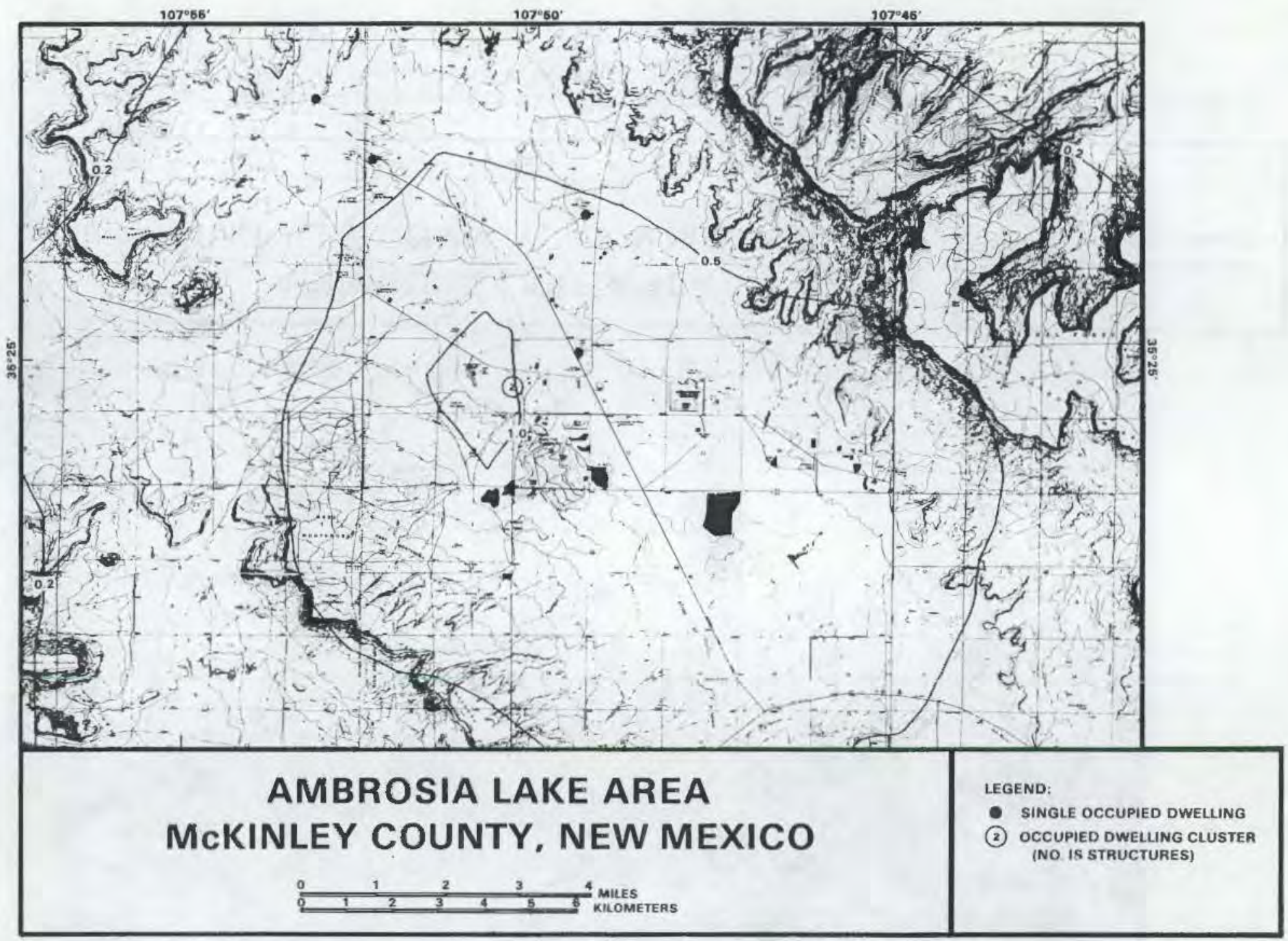

FIGURE 26. Estimated Incremental Radon Concentration Contours, PCi/L, Based on Multiple Mine Emissions Allowing for Plume Rise and All Vertical Vent Configurations 


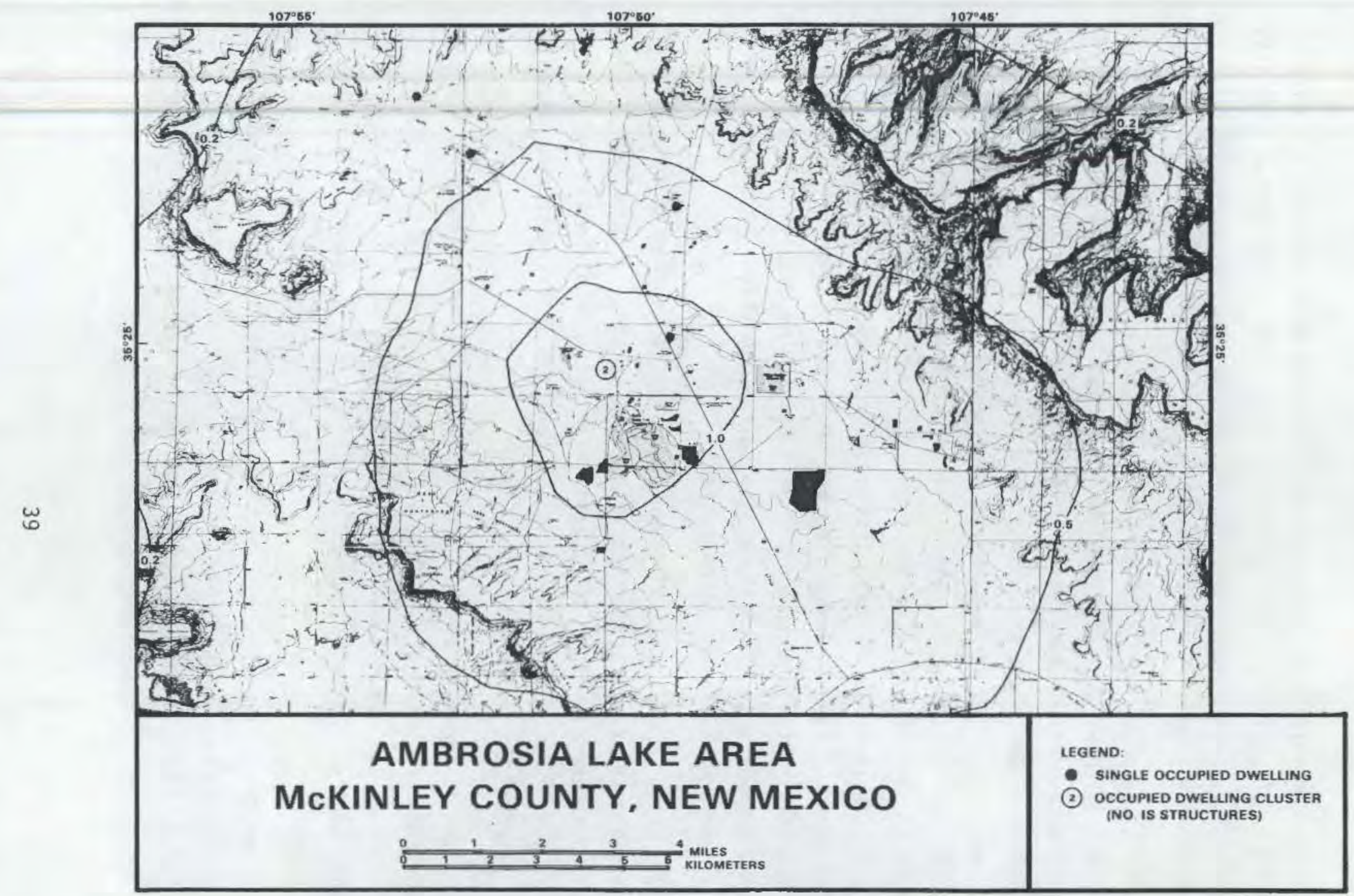

FIGURE 27. Estimated Incremental Radon Concentration Contours, pCi/L, Based on Multiple Mine Emissions Allowing for Plume Rise at All Vents Except Five Horizontal Vents at Case Study Mines 11 and 12 


\section{DISCUSSION}

The radon concentrations computed for the model mine and specific mines provide a basis of evaluating the importance of various parameters. Vent size and exit velocity, vent orientation, release height and local meteorology are a few of the major influences on the plume transport and dispersion processes.

Comparing the model mine contour plots with and without plume rise (Figures 2 and 3 ) shows that the no-plume-rise case has much larger predicted areas within each of the radon contour concentrations. The shape of contours are also different for these two cases. The plume rise case has contours offset to one side of the vents compared to a more circular pattern centered on the vents for the no-plume-rise case. The origin of this shift in patterns for the plume rise case appears to be the result of greater local high wind speeds from the west (Table A-7). Because little or no plume rise is expected at higher wind speeds, the high winds from the west result in greater concentrations to the east of the mining area. These model mine results clearly illustrate the importance of local meteorological conditions in determining patterns of incremental radon concentrations.

A wide variation of the area inside the radon concentration contours occurred between the case study mines (Figures 4 to 16). A major factor for the variation in the six mines with specific emission data was the range of the measured values. The relative locations of the contour areas between mines reflected differences in local winds.

Plume rise is shown to be an important factor in determining the estimated changes in long-term, average, surface level radon concentrations. At individual mines, the areas enclosed by the computed radon contours are considerably smaller for vents modeled with plume rise compared to vents with no plume rise.

A similar trend for vents with and without plume rise occurred with the multiple mine results. Much larger areas were enclosed by the computed contours for multiple mines than for any of the single mines. The plume rise 
mainly reduced the very high concentrations near the mine. Farther downwind, the predicted racon concentrations became the sane orcer of magritude.

As a result of the importance of plume rise, the crientation of the vent exhaust is critical. A vertical vent has an initial upward velocity, which is the main source of energy for plume rise. A horizontal vent has no initial vertical velocity, and is modeled as an area surface release with no plume rise. The individual and multiple mine computations with horizontal vent releases clearly show the importance of vent oriettation in escimated cadon concentrations in the fomedate vicinity of the mine.

These results indicate that no single computation will be representative of all mines. Depending on local conditions and fnfluences, the impact may be anywhere between maximum racon concentrations for a release with no phume rice and untum levels for a relese with plune rise. in addition the inpact will change depending on the radon entssion rate. 
REFERENCES

EPA. 1979. Industrial Source Complex Dispersion Model User's Guide. EPA-450/4-79-030 and EPA-450/4-79-031, Volumes I and II, U.S. Environmenta 1 Protection Agency, Washington, D.C.

EPA. 1983. Background Information Document, Proposed Standards for Radionuclides. EPA 520/1-83-001, U.S. Environmental Protection Agency, Washington, D.C.

EPA. 1984. Radionuclides - Background Information Document for Final Rules. EPA 520/1-84-022-2, U.S. Environmental Protection Agency, Washington, D.C.

Bruno, G. A., J. A. Dirks, P. 0. Jackson and J. K. Young. 1984. U.S. Uraniurn Mining Industry: Background Information on Economics and Emissions.

PNL-5035, Pacific Northwest Laboratory, Richland, washington.

Droppo, J. G., and J. A. Glissmeyer. 1981. An Assessment of the Radon Concentrations in Air Caused by Emissions From Multiple Sources in a Uranium Mining and Milling Region. A Case Study of the Mbrosia Lake Region of New Mexico. PNL-4033, Pacific Northwest Laboratory, Richland, Washington.

Holzworth, G. C. 1972. Mixing Heights, Wind Speeds, and Potential for Urban Air Pollution Throughout the Contiguous United States. U.S. Environmental Protection Agency, Office of Air Programs, Research Triangle Park, North Carolina.

Jackson, et al. 1980. An Investigation of Radon-?22 Emissions From Underground Uranium Mines. PNL-3262, Pacific Northwest Laboratory, Richland, Washington. 
APPENDIX A

METEOROLOGICAL SUMMARIES 
TABLE A-1a. Cedar City Meteorological Cata (Source 1 in Table $\mathrm{c}-1$ )

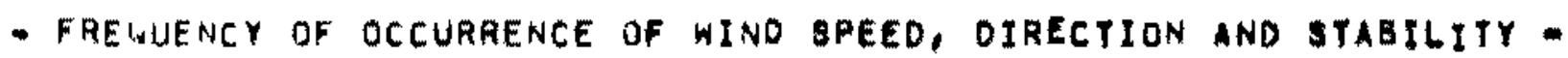

\section{SEASON 1}

\section{STABILITY CATEGORY}

WNU SPEED WINO SPEED WIND SPEEO WINO SPEED WINO SPEEO WINO SPEED
CATEGORY I CATEGIPY $(0.7500 \mathrm{MPS})(2.5000 \mathrm{MPB})(4.3000 \mathrm{MP} 8)(6.8000 \mathrm{MPS})(9.5000 \mathrm{MP} 3)(12.5000 \mathrm{MP})$

DIRECTIOI: (DEGRES)

$$
\begin{array}{r}
0.000 \\
22.500 \\
45.000 \\
67.500 \\
90.000 \\
112.500 \\
135.000 \\
157.500 \\
180.000 \\
202.500 \\
225.000 \\
247.500 \\
270.000 \\
292.500 \\
315.000 \\
337.500
\end{array}
$$

0.00000000

0.00017002

1). 00000000

1.00000000

0.00000000

11.600001100

1. 00000000

0.00000000

0.00000000

0.00000000

0.00000000

0.00000000

0.00000000

0.01000000

0.00000000

0.00000000
0.00000000

0.00000000

0.00000000

0.00000000

0.00000000

0.00000000

0.00000000

0.00000000

0.00000000

0.00000000

0.00000000

0.00000000

0.00000000

0.00000000

0.00000000

0.00000000
0.00000000

0.00000000

0.00000000

0.00000000

0.00000000

0.00000000

0.00000000

0.00000000

0.00000000

0.00000000

0.00000000

0.00000000

0.00000000

0.00000000

0.00000000

0.00000000
0.00000000

0.00000000

0.00000000

0.00000000

0.00000000

0.00000000

0.00000000

0.00000000

0.00000000

0.00000000

0.00000000

0.00000000

0.00000000

0.00000000

0.00000000

0.00600000
0.00000000 0.00000000 0.00000000 0.00000000

0.00000000

0.00000000

0.00000000

0.00000000

0.00000000

0.00000000

0.00000000

0.00000000

0.00000000

0.00000000

0.00000000

0.00000000 
TABLE A-1B.

SEASON 1

STABILITY CATEGOAY Z

DIRECTIOF (DEGREES)

$$
\begin{array}{r}
0.000 \\
22.500 \\
45.000 \\
67.500 \\
90.000 \\
112.500 \\
135.000 \\
157.500 \\
180.000 \\
202.500 \\
225.000 \\
247.500 \\
270.000 \\
292.500 \\
315.000 \\
337.500
\end{array}
$$

\begin{abstract}
WIND SPEED WINI SPEED WINO SPEED WIND SOEED WINO SPEED WINO SPEEO CATEGORY I CATEGORY 2 CATEGORY 3 CATEGORY a CATEGORY 5 CATEGDRY 6
\end{abstract} $(0.7500 \mathrm{MPg})(2.5000 \mathrm{MPB})(4.3000 \mathrm{MPS})(0.0000 \mathrm{MPS})(0.5000 \mathrm{MPS})(12.5000 \mathrm{MP})$

$\begin{array}{ll}0.00029004 & 0.00017002 \\ 0.00029004 & 0.00051007 \\ 0.00029004 & 0.00000000 \\ 0.00029004 & 0.00000000 \\ 0.00029004 & 0.00000000 \\ 0.00029004 & 0.00000000 \\ 0.00029004 & 0.00017002 \\ 0.00029004 & 0.00000000 \\ 0.00029004 & 0.00017002 \\ 0.00029004 & 0.00000000 \\ 0.00029004 & 0.00017002 \\ 0.00029004 & 0.00034005 \\ 0.00029004 & 0.00034005 \\ 0.00029004 & 0.00000000 \\ 0.00029004 & 0.00017002 \\ 0.00029004 & 0.00010000\end{array}$

0.00017002

0.00000000

0.00000000

0.00000000

0.00017002

0.00000000

0.00000000

0.00000000

0.00000000

0.00000000

$0.00000000 \quad 0.00000000$

$0.00000000 \quad 0.00000000$

0.00000000

0.00000000

0.00000000

0.00000000

0.00000000

0.00000000

0.00000000

.00000000

0,00000000

0.00000000

0.00000000

0.00000000

0.00000000

0.00000000

0.00017002

0.00034005

0.00000000

0.00000000

0.00034005

0.00000000

0.00000000

0.00000000

0.00000000

0.00000000

.0 .00000000

0.00000000

0.00000000

0.00000000

0.00000000

0.00000000

0.00000000

0.00000000

0.00000000

0.00000000

0.00000000

0.00000000

0.00000000

0.00000000

0.00000000

0.00000000

0.00000000

0.00000000

0.00000000

0.00017002

0.00000000

0.00000000

$0.00000000 \quad 0.00000000$ 
TABLE A-1C.

\section{SEASON 1}

STABILITY CATEGORY 3

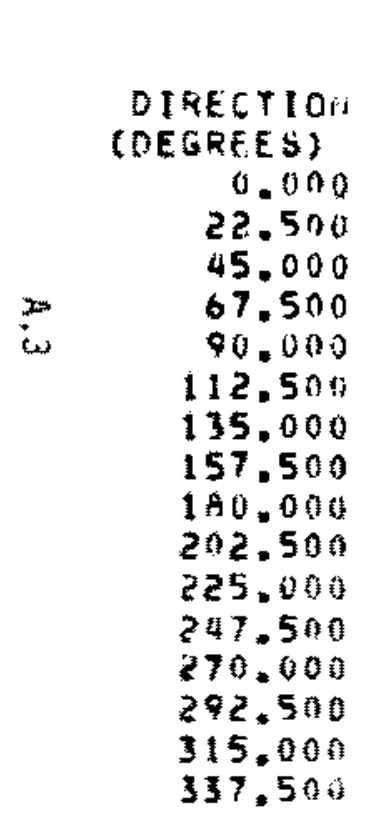


IABLE A-1d.

SEASON

SFBILITY CATEOORY A

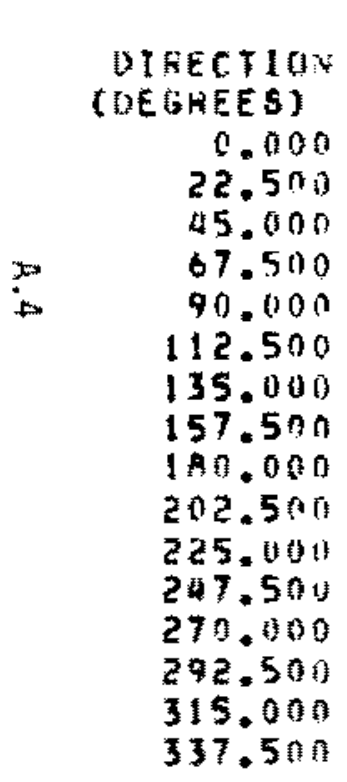

A) SPECD CATEGOKY 1 ( . .7500mos)

0.00292041

0.0029204 !

0.00309043

11.00292041

0.00292041

0.00292041

0.110292041

0.00309043

0.10309043

0.00292041

7), 010292014

0. 11129204

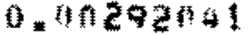

0 . 1329201

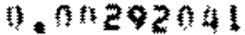

t). 01329044
WINI) SPEED

CATECORY

MND SPEED

CATEGORY 3

HNO SEED

CAYEGORY 4

WINO SPEEO CATEGORY 5 $(6.8000 \mathrm{mps})$

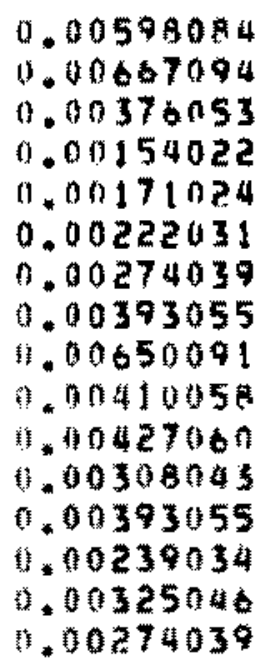

0.01471207 0.00855120 0.00308043 0.00103014 0.00183026 0.00188026 0.00513072 0.00547077 0.01197168 0.01881264

0.01676230 0.03967557 0.01129159

0.00462065

0.00393055

0.00205029

0.00239034

0.00547077 0.01505211 0.00256036 0.00051007 0.00154022 0.00120017 0.00154022 0.00103014 0.02274320 0.02394336

0.00547077

0.00445063

0.00120017 0.00137019

0.00108026 0.00239034 0.00000000 0.00000000 0.00017002 0.00017002 0.00017002 0.00060010 0.00942139 0.01522214 0.01009142 0.00085012 0.00120017 0.00017002 0.00034005 0.003760530 .00034005
WINO SPEEO CATEGORY 0.00085012 0.00034005 0.00000000 0.00000000 0.00000000 0.00000000 0.00017002 0.00000000 0.00513072 0.00496070 0.00068010 0.00000000 0.00034005 0.00000000 0.00000000 0.00000000 
TABLE A-1e.

- FHEOUENCY OF OCCURRENCE OF HIND SPEED, OIRECTION AND BTABLITY

SEASON 1

STABILITY CATEGORY 5

HIHD SPEEO WIND SPEED NIND SPEED WIND BPEED WIND SPEED WIND SPEED

DIRECTION (DEGREES)

0.000
22.500
45.000
67.500
90.000
112.500
135.000
157.500
180.000
202.500
225.000
247.500
270.000
292.500
315.000
337.500
CATEGORY 1 CATEGORY Z CATEGORY 3 CATEGORY 4 CATEGOAY 5 CATEGORY $(0.7500 \mathrm{MPS})(2.5000 \mathrm{MPS})(4.3000 \mathrm{MPS})(6.8000 \mathrm{MPS})(0.5000 \mathrm{MPS})(12.5000 \mathrm{MPg})$

$\begin{array}{ll}0.00446063 & 0.00633089 \\ 0.00446063 & 0.00547077 \\ 0.01446063 & 0.00376053 \\ 0.00440063 & 0.00180026 \\ 0.00446063 & 0.00239034 \\ 0.00446063 & 0.00359050 \\ 0.00463005 & 0.00769108 \\ 0.00446063 & 0.00598084 \\ 0.00446063 & 0.01146161 \\ 0.00446063 & 0.00547077 \\ 0.00446033 & 0.00479067 \\ 0.00446063 & 0.00325046 \\ 0.00446063 & 0.00342048 \\ 0.00446063 & 0.00103014 \\ 0.00446053 & 0.00222031 \\ 0.00446063 & 0.00120017\end{array}$

0.00872122
0.00547077
0.00393055
0.00120017
0.00256038
0.00821115
0.02137300
0.02103295
0.02069291
0.01590223
0.00547077
0.00222031
0.00085012
0.00017002
0.00034005
0.00120017

0.00103014 0.00030005 0.00000000 0.00000000

0.00017002

0.00000000

0.00000000

0.00034005

0.00171024

0.00239034

0.00137019

0.00017002

0.00017002

0.00000000

0.00000000

0.00000000
0.00017002

0.00017002

0.00000000

0.00000000

0.00000000

0.00000000

0.00017002

0.00000000

0.00017002

0.00034005

0.00017002

0.00000000

0.00000000

0.00000000

0.00000000

0.00000000
0.00000000

0.00000000

0.00000000

0.00000000

0.00000000

0.00000000

0.00000000

0.00000000

0.00000000

0.00000000

0.00000000

0.00000000

0.00000000

0.00000000

0.00000000

0.00000000 
IABLE A-1f.

SEASDN 1

STARLITY CATECORY

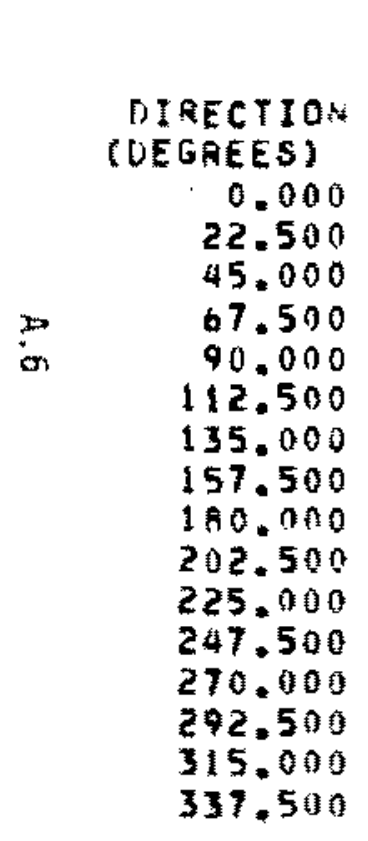

WID EPEEO WINO SPEED WIND SPEEO WINO GPEEO CATEGORY CHTEGORY 2 CATEGOAY 3 CATEGOAY 4 CHTEGORY 5 CATEGORY

WIND SPEED WIND BPEED $(0.7500 \mathrm{MPS})(2.5000 \mathrm{MPS})(4.3000 \mathrm{MP})(6.6000 \mathrm{KPS})(9.5000 \mathrm{MPS})(12.5000 \mathrm{MP})$

$\begin{array}{ll}0.00791111 & 0.00256036 \\ 0.00791111 & 0.00342048 \\ 0.00774109 & 0.00564079 \\ 0.097741199 & 0.00427060 \\ 0.00771109 & 0.00684096 \\ 0.00791111 & 0.00547077 \\ 0.00774109 & 0.01573221 \\ 0.00791111 & 0.01300143 \\ 0.00908114 & 0.01556219 \\ 1.00771119 & 0.00752106 \\ 0.00774119 & 0.00376053 \\ 0.00774109 & 0.00222031 \\ 0.00774109 & 0.00137019 \\ 0.00771109 & 0.00103014 \\ 0.00774109 & 0.00085012 \\ 0.00774190 & 0.00103014\end{array}$

0.00034005

0.00000000

0.00017002

0.00000000

0.00051007

0.00000000

0.00000000

0.00000000

0.00000000

0.00017002

0.00000000

0.00000000

0.00000000

0.00000000

00000000

0.00000000

0.00000000

0.00000000

0.00000000

0.00000000

0.00120017

0.00000000

0.00000000

0.00000000

0.00051007

0.00000000

0.00000000

0.00000000

0.00051007

0.00000000

0.00000000

0.00000000

0.00034005

0.00017002

0.00000000

0.00000000

0.00034005

0.00017002

0.00000000

0.00000000

0.00017002

0.00017002

0.00000000

0.00000000

0.00000000

0.00000000

0.00000000

0.00000000

0.00000000

0.00000000

00000000

0.00000000

0.00000000

0.00000000

0.00000000

0.00000000

0.00000000

0.00000000

0.00000000

0.00000000

0.00000000 
TABLE A-2a. Grand Junction/urvan Meteorological Data (Source 2 in Table C-1)

- FREQUENCY OF OCCUARENCE OF WINO SPEED, DIRECTION ANO BTABILITY -

SEASON I

STABRLITY CATEGORY I

WINO SPEED WINO SPEEO WIND SPEEO MIND SPEEO WINO SPEEO WIND SPEED CATEGORY I CATEGORY 2 CATEGORY 3 CATEGORT A CATEGORY 5 CATEGORY

DIRECTION

(OEGFES)

0.000

22.500
45.000

67.500

90.000

112.500

135.000

157.500

180.000

202,500

225.010

247.500

270.000

292.500

315.000

337.500
$(0.7500 \mathrm{mps})$

0.00009103

0.00036413

0.00018207

0.00027310

0.00154756

0.00513849

0.00782830

0.00127447

0.00081930

0.00009103

$0.0 n 018267$

0.60009103

0.0004551?

0.00045517

0.00091033

0.00436913
0.00000000

0.00000000

11.00000000

0.00000000

0.00000000

c.00000000

0.00000000

0.00000000

0.00000000

0.00000000

tz. entongnon

0.00000000

$0.001) 00000$

0.00000000

0.00000000

0.00000000
0.00000000

0.00000000

0.00000000

0.00000000

0.00000000

0.00000000

0.00000000

0.00000000

0.00000000

0.00000000

0.00000000

1.00000000

0.00000000

0.00000000

0.00000000

0.00000000
0.00000000

0.00000000

0.00000000

0.00004000

0.00000000

0.00000000

0.00000000

0.00000000

0.00000000

0.00000000

0.00000000

0.00000000

0.00000000

0.00000000

0.00000000

0.00000000
( 9000 APS) (12,5000MP s)

0.00000000

0.00000000

0.00000000

0.00000000

0.00000000

0.0000000 月

0.00000000

0.00000000

0.00000000

0.00000000

0.00000000

0.00000000

0.00000000

0.00000000

0.00000000

$0 ., 00000000$

0.00000000

0.00000000

0.00000000

0.00000000

0.00000000

0.00000000

0.00000000

0.00000000

0.00000000

0.00000000

0.00000000

0.00000000

0.00000000

0.00000000

0.00000000

0.00000000 
TABLE $A-2 b$.

SEASON 1

STAELLITY CATEGORY 2

DIRECIIOH (OEGREES)

0.000
22.500
45.000
67.500
90.000
112.500
135.000
157.500
130.000
202.500
225.001
247.500
270.000
292.500
315.000
337.500

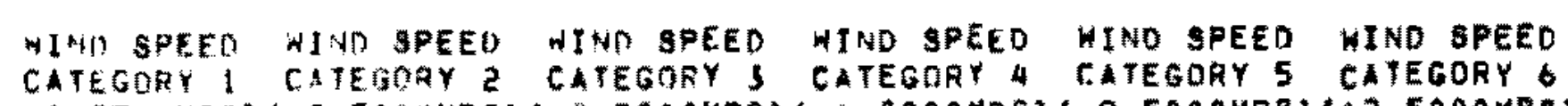
$(0.7500$ MPS) ( 2.500 MPS $)(4.3000 \mathrm{MPS})(0.0000 \mathrm{MP})(9.5000 \mathrm{MPS})(12.5000 \mathrm{MP})$

$\begin{array}{lllll}0.00036413 & 0.00045517 & 0.00000000 & 0.00000000 & 0.00000000 \\ 0.00127447 & 0.00063723 & 0.00000000 & 0.00000000 & 0.00000000 \\ 0.00063723 & 0.00018207 & 0.00000000 & 0.00000000 & 0.00000000 \\ 0.00091033 & 0.00009103 & 1.00000000 & 0.00000000 & 0.00000000 \\ 0.00591710 & 0.00063723 & 0.00000000 & 0.00000000 & 0.00000000 \\ 0.01948111 & 1.00191170 & 0.00000000 & 0.00000000 & 0.00000000 \\ 0.02958580 & 0.00346609 & 0.00000000 & 0.00000000 & 0.00000000 \\ 0.00473373 & 1.00200273 & 0.00000000 & 0.00000000 & 0.00000000 \\ 0.00318616 & 0.00072827 & 0.00000000 & 0.00000000 & 0.00000000 \\ 0.00036413 & 0.07018207 & 0.00000000 & 0.00000000 & 0.00000000 \\ 0.00072427 & 1.00027310 & 0.00000000 & 0.00000000 & 0.00000000 \\ 0.001127310 & 1.00009103 & 0.00000000 & 0.00000000 & 0.00000000 \\ 0.00172933 & 1.00063723 & 0.00000000 & 0.00000000 & 0.00000000 \\ 0.00182066 & 0.00136550 & 0.00000000 & 0.00000000 & 0.00000000 \\ 0.00327720 & 0.015527993 & 1.00000000 & 0.00000000 & 0.00000000 \\ 0.00118343 & 0.00227583 & 0.00000000 & 0.00000000 & 0.00000000\end{array}$

0.00000000

0.00000000

0.00000000

0.00000000

0.00000000

0.00000000

0.00000000

0.00000000

0.00000000

0.00000000

0.00000000

0.00000000

0.00000000

0.00000000

0.00000000

0.00000000 


\section{TABLE A-2c.}

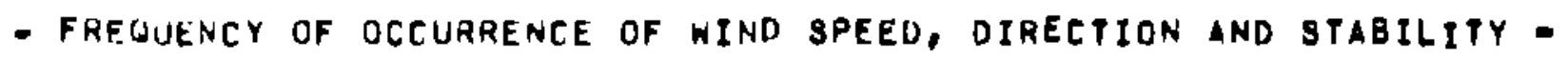

SEASON 1

STARILITY CATEGORY 3

WIHD SPEED WJND SPEED WIND SPEED WIND SPEED WIND SPEED WIND SPEED
CATEGORY I CATEGORY 2 CATEGORY 3 CATEGORY 4 CATEGORY 5 CATEGORY 6

DIRECTION (DEGREES)

0.000
io $\quad 22.500$

45.000

67.500

90.000

112.500

135.000

157.500

180.000

202.501

225.000

247.500

270.000

292.500

315.000

337.500
0.00000000

0.00000000

0.00000000

0.011000000

0.00000000

0.00000000

0.00000000

0.00000000

0.00000000

0.00000000

0.00000000

0.00000000

0.00000000

0.00000000

0.00000000

0.00000000
$(0.7500 \mathrm{MPS})($

\subsection{3}

0.00309513

0.00109240

0.00045517

0.00327720

1). 09649523

0.04269459

0.01010469

0.00373236

0.00100137

0.00127447

0.00054620

0.00300410

0.00682749

0.02667274

0.01165225
0.00000000

0.00000000

0.00000000

0.00000000

0.00000000

0.00000000

0.00000000

0.00000000

0.00000000

0.00000000

0.00000000

0.00000000

0.00000000

0.00000000

0.00000000

0.00000000
CATEGORY 6

0.00000000

0.00000000

0.00000000

0.00000000

0.00000000

0.00000000

0.00000000

0.00000000

0.00000000

0.00000000

0.00000000

0.00000000

0.00000000

0.00000000

0.00000000

0.00000000
0.00000000

0.00000000

0.00000000

0.00000000

0.00000000

0.00000000

0.00000000

0.00000000

0.00000000

0.00000000

0.00000000

0.00000000

0.00000000

0.00000000

0.00000000

0.00000000
0.00000000

0.00000000

0.00000000

0.00000000

0.00000000

0.00000000

0.00000000

0.00000000

0.00000000

0.00000000

0.00000000

0.00000000

0.00000000

0.00000000

0.00000000
0.00000000 
TABLE $A-2 d$.

SEASON 1

STABILITY CATEGORY a

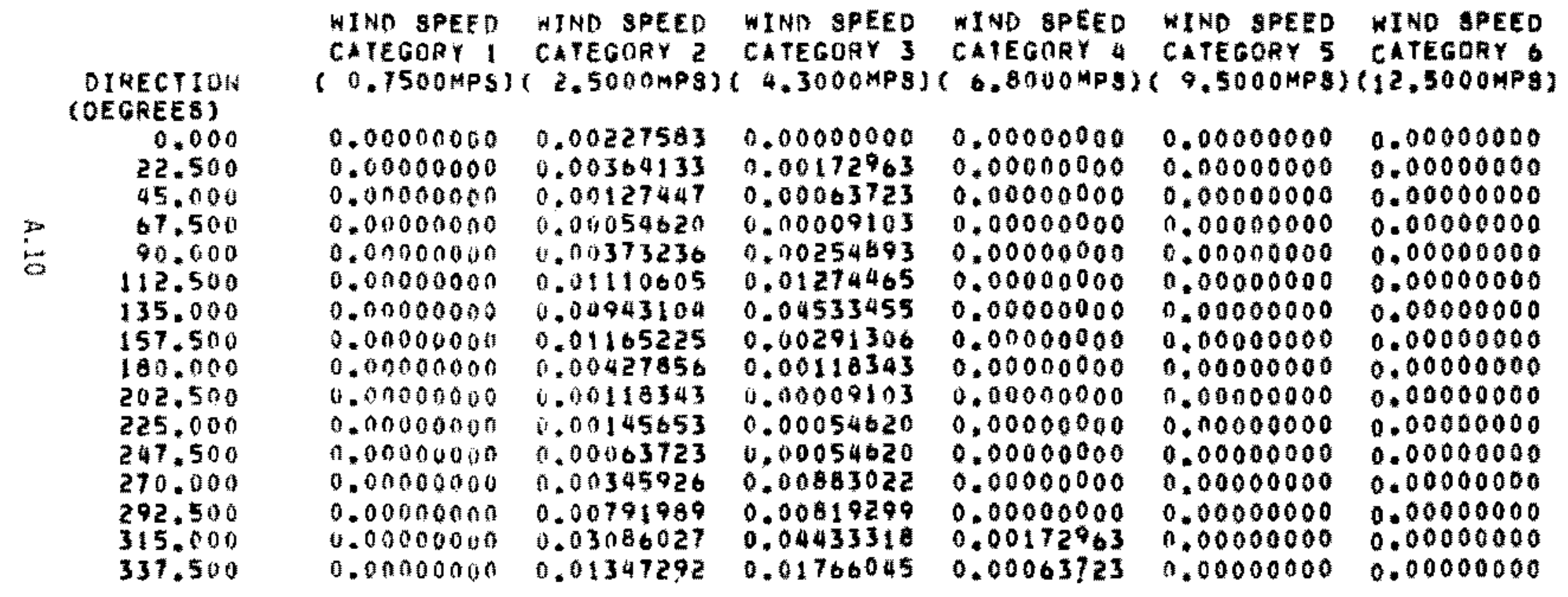


TABLE A-2e.

- FREQUEREY OF OCCIARENCE OF WIND SPEED, OIRECTION AND STABILITY -

$5 E M O N 1$

GTABILIYY CATEGORY 5

HINO SPEED AIND SPEED WINO SPEED WIND SPEED KINO SPEED WIND SPEED CATEGORY 1 CATEGORY 2 CATEGORY 3 CATEGORY G CATEGORY 5 CATEGORY $(0.7500 \mathrm{MPS})(2.5000 \mathrm{MPS})(4.3000 \mathrm{MP})(6.8000 \mathrm{MPS})(9.5000 \mathrm{MPS})(12.5000 \mathrm{MP})$

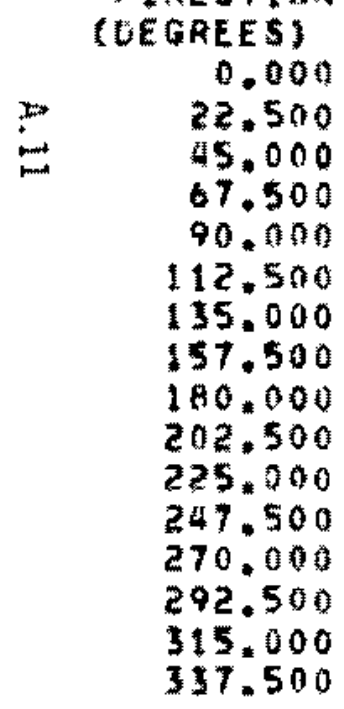

0.00054620

0.00182060

0.00091033

0.00127447

0.00828402

0.02703687

0.04114702

0.00055430

0.00436960

0.01054620

0.00100137

0.01036413

0.0023606

0.00254893

$0.0 n 455160$

0.00172963

\subsection{3}

0.00081930

0.00027310

0.00009103

0.01091033

0.00263996

0.01174329

0.00252203

0.00100137

0.00027310

0.00036413

0.00018207

0.00081930

(1.00191170

1). 40) 73736

0.00318616
0.00000000

0.00000000

0.00000000

0.00000000

0.00000000

0.00000000

0.00000000

0.00000000

0.00000000

0.00000000

0.00000000

0.00000000

0.00000000

0.00000000

0.00000000

0.00000000
0.00000000

0.00000000

0.00000000

0.00000000

0.00000000

0.00000000

0.00000000

0.00000000

0.00000000

0.00000000

0.00000000

0.00000000

0.00000000

0.00000000

0.00000000

0.00000000
0.00000000

0.00000000

0.00000000

0.100000000

0.00000000

0.00000000

0.00000000

0.00000000

0.00000000

0.00000000

0.00000000

0.00000000

0.00000000

0.00000000

0.00000000

0.00000000
0.00000000

0.00000000

0.00000000

0.00000000

0.00000000

0.00000000

0.00000000

0.00000000

0.00000000

0.00000000

0.00000000

0.00000000

0.00000000

0.00000000

0.00000000

0.00000000 
IABLE A-2f.

SEASON I

STABILITY CATEGORY

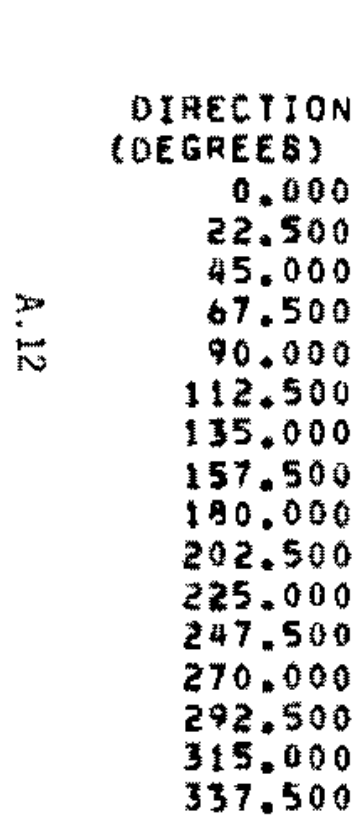

WINO SPEED CATEGORY 1 $(0,7500 \mathrm{MPS})$

\subsection{7}

0.00409650

0.00200273

0.00309513

0.01756941

0.0580 .2540

0.08921257

0.01447428

0.00923539

0.00100137

0.00200273

0.00100137

0.00518889

0.00518889

0.01037779

0.00409650
WINO SPEED CHEGORY ? z.5000MPs)

\subsection{0}

0.00000000

0.00000000

0.00000000

0.00000000

0.00000000

0.00000000

0.00000000

0.00000000

0.00000000

i. .00000000

0.00000000

0.00000000

0.00000000

0.00000000

0.00000000
WINO SPEED

CATEGORY 3

WINO SPEED

CATEGORY

IIND SPEEO CATEGORY 5

WIND SPEED

0.00000000

0.00000000

0.00000000

0.00000000

0.00000000

0.00000000

0.00000000

.00000000

0.010000000

0.00000000

0.00000000

0.00000000

0.00000000

0.00000000

0.00000006
0.00000000

0.00000000

0.00000000

0.00000000

0.00000000

0.00000000

0.00000000

0.00000000

0.00000000

0.00000000

0.00000000

0.00000000

0.00000000

0.00000000

0.00000000

\subsection{0}

0.00000000

0.00000000

0.00000000

0.00000000

0.00000000

0.00000000

0.00000000

0.00000000

0.00000000

0.00000000

0.00000000

0.00000000

0.00000000

0.00000000

0.00000000
CATEGORY
0.00000000 0.00000000 0.00000000 0.00000000 0.00000000 0.00000000 0.00000000 0.00000000 0.00000000 0.00000000 0.00000000 0.00000000 0.00000000 0.00000000 0.00000000 0.00000000 
TABLE A-3a. Grand Junction/Urvan/Lisban Meteorological Data (Source 3 in Table C-1)

- FREUUENCY DF OCCURRENCE OF WIND SPEED, DIRECTION AND STAGILITY.

\section{SEASON 1}

STABLITY CATEGORY

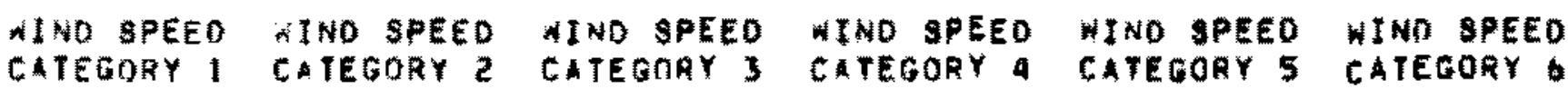

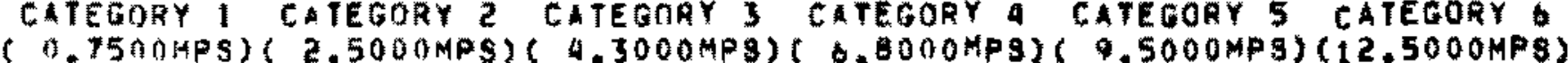

DIHECTIOH
(DEGAEES)
0.000
22.500
45.000
67.500
90.000
112.500
135.000
157.500
180.000
202.500
225.000
247.500
270.000
292.500
315.000
337.500

0.00000000

0.00000000

0.00000090

0.000100100

0.40000030

0. 00000030

$0.000000 \% 0$

0.00000000

0.00000000

0.00000000

1). 0100000000

0.00000000

0.00000400

0.00000000

0.00000000

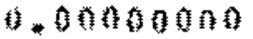

0.00000000

0.00000000

0.00000000

0.00000000

0.00000000

7.00000000

0.00000000

0.00000000

0.00000000

0.00000000

0.00000000

0.00000000

0.00000000

0.00000000

0.00000000

0.00000000

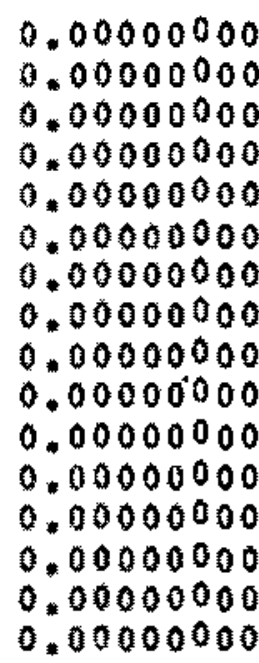

0.00000000

0.00000000

0.00000000

0.00000000

0.00000000

0.00000000

0.00000000

0.00000000

0.00000000

0.00000000

0.00000000

0.00000000

0.00000000

0.00000000

0.00000000

0.00000000

0.00000000

0.00000000

0.00000000

0.00000000

0.00000000

0.00000000

0.00000000

0.00000000

0.00000000

0.00000000

0.00000000

0.00000000

0.00000000

0.00000000

0.00000000

0.00000000 
TABLE A-3b.

SEASON

STABLITY CATEGORY

HINO SPEEO AINO SPEED WINO SPEEO WINO SPEED WINO SPEED WINO SPEED $(0.7500 \mathrm{HOS})(2.5000 \mathrm{MPS})(4.3000 \mathrm{HPS})(6.8000 \mathrm{MPS})(9.5000 \mathrm{MPS})(12.5000 \mathrm{MPS})$

DIRECTIUN (DEGREES)

0.000

22.500

45.000

67.500

90.000

112.500

135.000

157.500

100.000

202.500

225.000

247.500

270.000

292.5010

315.000

337.500

\subsection{0}

0.00000000

0.00000000

0.00000000

0.00000000

0.00000000

0.00000000

0.00000000

0.00000000

0.00000000

a. ก0บ0000

0.00000010

0.05003050

0.10000000

0.06000000

औ. 0 21300000
0.00034892

0.00147619

0.00093940

0.00530797

0.00730044

0.02734982

1). 00845456

0.00571689

1).00150303

1. 00316710

0.00099300

4.00277750

6.00225455

0.00418102

7.00003204

4.00193247
0.00045628

0.00072468

0.00026840

0.00053680

0.00077836

0.00268399

0.00241559

0.00241559

0.00034892

0.00158355

0.00037576

0.00158355

0.00083204

0.00314026

0.00134190

$0.003730 \%$
0,00000000

0.00000000

0.00000000

0.00000000

0.00000000

0.00000000

0.00000000

0.00000000

0.00000000

0.00000000

0.00000000

0.00000000

0.00000000

$0.000000 \% 0$

0.00000000

0.00000000
0.00000000

0.00000000

0.00000000

0.00000000

0.00000000

0.00000000

0.00000000

0.00000000

0.00000000

0.00000000

0.00000000

0.00000000

0.00000000

0.00000000

0.00000000

0.00000000
0.00000000

0.00000000

0.00000000

0.00000000

0.00000000

0.00000000

0.00000000

0.00000000

0.00000000

0.00000000

0.00000000

0.00000000

0.00000000

0.00000000

0.00000000

0.00000000 
TABLE A-3C.

- FREUUENCY OF OCCURRENCE OF HINO SPEED, DIRECTION HNO STABILITY -

SEASON

STMBILITZ CATEGORY 3

WINU SPEED WIND SPEED WIND SPEED WIND SPEED WINO SPEED WIND SPEED CATEGORY I CATEGORY 2 CATEGORY 3 CATEGORY 4 CAFEGQRY 5 CATEGORY

OIRECTION

( $0.7500 \mathrm{MPS}) \mathrm{t}$

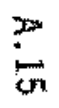

(LEGREES)

$\begin{array}{rrr}0.000 & 0.00000000 & 0.00000000 \\ 22.500 & 0.00000000 & 0.00000000 \\ 45.000 & 0.00000000 & 0.00000000 \\ 67.500 & 0.00000000 & 0.00000000 \\ 90.000 & 0.00000000 & 0.00000000 \\ 112.500 & 0.00000000 & 0.00000000 \\ 135.000 & 0.00000000 & 0.00000000 \\ 157.500 & 0.00000000 & 0.00000000 \\ 180.000 & 0.01000000 & 0.00000000 \\ 202.500 & 0.01000000 & 0.00000000 \\ 225.000 & 0.00000000 & 0.00000000 \\ 247.500 & 1.000000110 & 0.00000000 \\ 270.000 & 0.00000000 & 0.00000000 \\ 292.500 & 0.000000100 & 0.00000000 \\ 315.000 & 0.000000000 & 0.00000000 \\ 337.500 & 0.00000000 & 0.00000000\end{array}$

0.00222771

0.00356970

0.00161039

0.00268399

0.00402598

0.13546079

0.01218530

0.01216530

0.00174459

0.00872296

0.00171775

0.00955499

0.00391862

0.01572016

0.00681733

0.01910998
0.00000000

0.00000000

0.00000000

0.00000000

0.00000000

0.00000000

0.00000000

0.00000000

0.00000000

0.00000000

0.00000000

0.00000000

0.00000000

0.00000000

0.00000000

0.00000000
0.00000000

0.00000000

0.00000000

0.00000000

0.00000000

0.00000000

0.00000000

0.00000000

0.00000000

0.00000000

0.00000000

0.00000000

0.00000000

0.00000000

0.00000000

0.00000000
0.00000000

0.00000000

0.00000000

0.00000000

0.00000000

0.00000000

0.00000000

0.00000000

0.00000000

0.00000000

0.00000000

0.00000000

0.00000000

0.00000000

0.00000000

0.00000000 


\section{TABLE A-3d.}

SEASON I

\section{STAOLLITY CATEGORY 4}

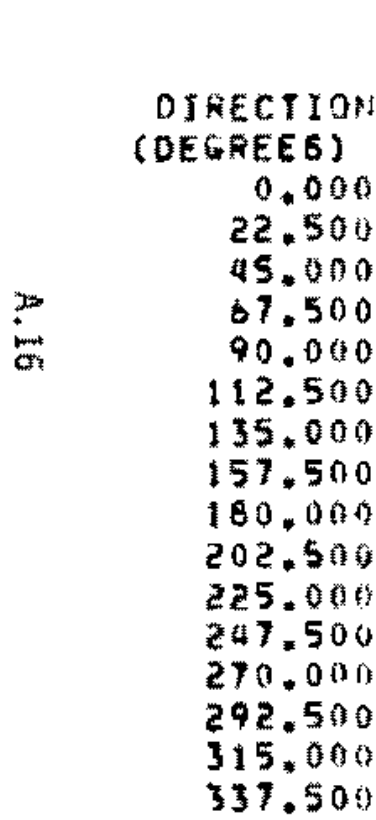
WIND SPEEO WINO SPEEO WINO SPEED
CIEGORY I CATEOORY 2 CATEGORY $(0.7500 \mathrm{mps})$

0.00000000

0.00000000

0.00000000

0.00000000

0.000000000

0.061000000

0.00000000

0.00000000

0.00000000

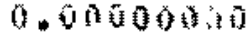

0 . watoonon

$0.0000000 \mathrm{n}$

0.000000 a

0.00000000

0.00000 ton

6.0.00000

\subsection{0} 0.00008000 0.00000000 0.00000000 0.00000000 0.00000000 0.00000000 0.00000000 0.00000000 U. 00000000 0.00000000 0.00000000 0.00000000 i). 00000000 0.00000000

0.00000000

\subsection{1}

0.00415702

0.00187879

$0.0032207 \mathrm{~s}$

0.00458962

0.01559396

0.01411777

0.01403725

0.00201299

0.01033335

0.00195931

0.01113854

0.00450910

0.018z5111

0.00789092
0.02211605
WIND SPEED

CATEGORY a

WINO SPEED

CATEGORY 5

WIND BPEED

\subsection{0}

0.00000000

0.00198015

0.00093940

0.00000000

0.00053680

0.00000000

0.00000000

0.00314026

0.00000000

0.01790219

0.01293681

0.00000000

0.00000000

0.00000000

.00351602

0.00056364

0.0000520

0.00000000

0.00000000

0.00072468

0.00955499

0.00000000

0.01151430

00000000

0.01889520

0.00000000

0.01132642

0.00000000

0.00042944

$0.02898706 \quad 0.00104675$
0.00000000

0.00000000

0.00000000

0.00000000

0.00000000

0.00000000

0.00000000

0.00000000

0.00000000

0.00000000

0.00000000

0.00000000

0.00000000

0.00000000

0.00000000

0.00000000 
TABLE A-3e.

- FREQUENCY OF DCCUARENCE OF NIND SPEED, OIRECTION AND STABILITY -

SE SON 1

STABILITY CATEGORY 5

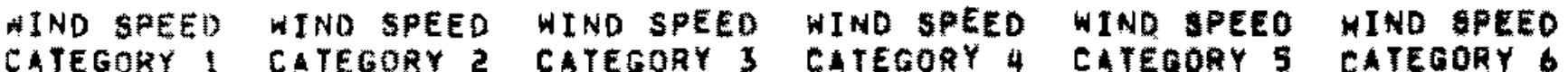

DIRECTIOH (DEGREES)

0.000

22.500
45.000
67.500

6.500
90.000

112,500

135.000

157.500

180.000

202.500

225.000

247.500

270.000

292.500

315.000

337.500

$(0.7500 \mathrm{MPS})(2.5000 \mathrm{MPS})(4.3000 \mathrm{MPS})(6.8000 \mathrm{MPS})($

$9.5000 \mathrm{MPS})(12.5000 \mathrm{MP})$

$\begin{array}{lll}0.00000000 & 0.00053680 & 0.00061732 \\ 0.00000000 & 0.00209351 & 0.00093940 \\ 0.00000000 & 0.00134199 & 0.00040260 \\ 0.00000000 & 0.00751516 & 0.00053600 \\ 0.00000000 & 0.01019915 & 0.00112727 \\ 0.00000000 & 0.03795157 & 0.00370390 \\ 0.00000000 & 0.01175586 & 0.00335498 \\ 0.00000000 & 0.00789092 & 0.00340866 \\ 0.00000000 & 0.00206667 & 0.00048312 \\ 0.00001000 & 0.00475066 & 0.00238875 \\ 0.010000100 & 0.00134199 & 0.00048312 \\ 0.00000001 & 0.00636105 & 0.00319394 \\ 0.000000100 & 0.00308658 & 0.00107359 \\ 0.00000000 & 0.00587793 & 0.00440174 \\ 0.00000000 & 0.00115411 & 0.00187879 \\ 0.00000000 & 0.00284503 & 0.00523377\end{array}$

0,00000000

0.00000000

0.00000000

0.00000000

0.00000000

0.00000000

0.00000000

0.00000000

0.00000000

0.00000000

0.00000000

0.00000000

0.00000000

0.00000000

0.00000000

0.00000000

0.00000000

0.00000000

0.00000000

0.00000000

0.00000000

0.00000000

0,00000000

0.00000000

0.00000000

0.00000000

0.00000000

0.00000000

0.00000000

0.00000000

0.00000000

0.00000000

0.00000000

0.00000000

0.00000000

0.00000000

0.00000000

0.00000000

0.00000000

0.00000000

0.00000000

0.00000000

0.00000040

0.00284503

0.00523377

0.00000000

0.00000000

0.00000000

0.00000000

0.00000000

0.00000000 
TABLE A-3f.

SEASON 1

STABILITY CATEGORY

DIRECTION (OEGREES)

0.000

$22.50 \%$

45.000

07.500
$5 \quad 90.000$
$5 \quad 117.500$

to 112.500

135.000

157.510

180.500

202.500

225.000

247.500

270.0110

292.500

315.000

$337.50 \%$

\section{* INO SPEEO}

CHETORY 1

C IEGTRY

WINA SPEED

CATEGUAY 3

WIND SPEEO

WINO SPEED

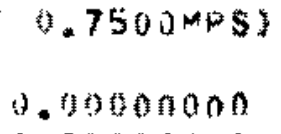

0. .06000000

$0.0000000 \mathrm{n}$

6.

0.00000050

0.

0.0neadon

0.00000000

1. 0nongento

(4. 1)

0.001000000

t). $6(510000 t *$

E. 050000.10

0.00 tonatoo

n. snomano

0 . Dotogona

\subsection{8}

0.00472382

0.00295239

1. . 11827795

. . 02163293

19.68231781

6.02547103

0.01744591

0.00437490

0.00172296

0.00271083

0.00676365

10.00205715

1).00070997
4.01752643

0.01107058
0.00000000

0.00000000

0.00000000

0.00000000

0.00000000

7.00000000

0.00000000

0.00000000

0. מnotuon

0.00000000

0.00000000

0.00000000

0.00000000

0.00000000

0.00000000
0.00000000
0.00000000

0.00000000

0.00000000

0.00000000

0.00000000

0.00000000

0.00000000

0.00000000

0.00000000

0.00000000

0.00000000

0.00000000

0.00000000

0.00000000

0.00000000

0.00000000
CATEGORY 5 CATEGORY 6

0.00000000

0.00000000

0.00000000

0.00000000

0.00000000

0.00000000

0.00000000

0.00000000

0.00000000

0.00000000

0.00000000

0.00000000

0.00000000

0.00000000

0.00000000

0.00000000
0.00000000

0.00000000

0.00000000

0.00000000

0.00000000

0.00000000

0.00000000

0.00000000

0.00000000

0.00000000

0.00000000

0.00000000

0.00000000

0.00000000

0.00000000

0.00000000 
TABLE A-4a. Casper Meteorological Data (Source 4 in Table C-1)

- Frequencr of ocCURRENCE OF WINO SPEED, OIRECTION ANO OTHBILITY -

SELOON 1

STABILITY CATEGORY

WND SPEED WIND SPEED WINO SPEEO WINO SPEED WINO SPEED WINO SPEED
CHTEGORY 1 CATEOORY 2 CATEGORY 3 CAIEGORY 4 CATEGORY 5 CATEGORY

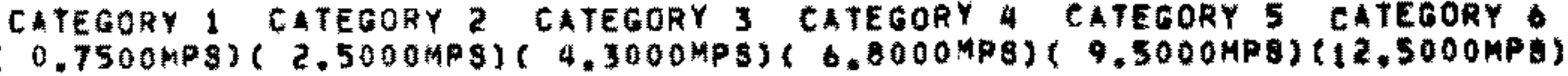

OIRECTYON
OECREE
0.000
22.500
45.000
67.500
90.000
112.500
135.000
157.5100
180.000
202.500
225.000
247.500
270.000
292.500
315.000
337.500

$\begin{array}{lll}0.00000000 & 0.00000000 & 0.00000000 \\ 0.00000000 & 0.00000000 & 0.00000000 \\ 0.00000000 & 0.00000000 & 0.00000000 \\ 0.00000000 & 0.00000000 & 0.00000000 \\ 0.00000000 & 0.00000000 & 0.00000000 \\ 0.00000000 & 0.00000000 & 0.00000000 \\ 0.00000000 & 0.00000000 & 0.00000000 \\ 0.00000000 & 0.00000000 & 0.00000000 \\ 0.00000000 & 0.00000000 & 0.00000000 \\ 0.00000000 & 0.00000000 & 0.00000000 \\ 0.00000000 & 0.00000000 & 0.00000000 \\ 0.00000000 & 0.00000000 & 0.00000000 \\ 0.00000000 & 0.00000000 & 0.00000000 \\ 0.00000000 & 0.00000000 & 0.00000000 \\ 0.00000000 & 0.00000000 & 0.00000000 \\ 0.00000000 & 0.00000000 & 0.00000000\end{array}$

0.00000000 0.00000000 0.00000000 0.00000000 0.00000000 0.00000000 0.00000000 0.00000000 0.00000000 0.00000000 0.00000000 0,00000000 0.00000000 0.00000000 0.00000000 0.00000000
0.00000000
0.00000000
0.00000000
0.00000000
0.00000000
0.00000000
0.00000000
0.00000000
0.00000000
0.00000000
0.00017003
0.00000000
0.00000000
0.00000000
0.00000000
0.00000000
0.00000000 0.00000000 0.00000000 0.00000000 0.00000000 0.00000000 0.00000000 0.00000000 0.00000000 0.00000000 0.00000000 0.00000000 0.00000000 0.00000000 0.00000000 0.00000000 
TABLE A-4b.

\author{
SEASON 1
}

STHEILITY CATEGORY Z

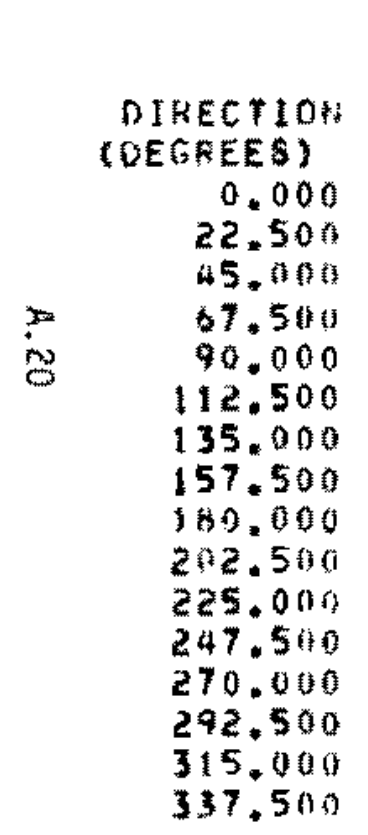

WIHA SEEO CATEGOAY I $(0.7500 \mathrm{mps})$

\subsection{0}

0.20000000

0.00000000

0.00000000

0.00017003

0.00000000

0.00000000

0.00000000

0.00017003

0.00000000

0.00000000

0.00034006

0.00034006

0.00000000

0.00000000

0.00017003
WIND SPEED CATEGORY

WIND GPEED

CATEGORY 3

WIND SPEED

CATEGORY A

THD SPEED

WINO SPEED

0.00017003

0.00034006

0.00017003

0.00051009

0.00017003

0.00068012

0.00017003

0.00051009

0.00034006

0.00051009

0.70034006

1.00085015

0.00017003

0. 10120022

0.00034006

0.00051009

0.00051009
0.00051009

0.00017003

0.00068012

0.00000000

0.00000000

0.00000000

0.00000000

0.00034006

0.00017003

0.00034016

0.00000000

0.00034006

0.00017003

0.00017003

0.00085015

0.00017003

0.00051009

0.00000000

0.00017003
0.00000000

0.00000000

0.00000000

0.00000000

0.00000000

0.00000000

0.00000000

0.00000000

0.00000000

0.00017003

0.00000000

0.00000000

0.00000000

0.00000000
CATEGORY 5

$\begin{array}{lll}0.00000000 & 0.00000000 & 0.00000000 \\ 0.00000000 & 0.00000000 & 0.00000000\end{array}$

$\begin{array}{lll}0.00000000 & 0.00000000 & 0.00000000 \\ 0.00000000 & 0.00000000 & 0.00000000\end{array}$

CATEGORY

0.00000000 0.00000000

0.00000000

0.00000000

0.00000000

0.00000000

0.00000000

0.00000000

0.00000000

0,00000000

0.00000000

0.00000000

0.00000000

0.00000000

0.00000000 
IABLE A-4C.

- FREQUENCY OF OCCURRENCE OF WIND SPEED, OIRECTION AND GTABILITY -

SEASON 1

STABILITY CATEGORY 3

HIUD BPEED HIND SPEED WIND BPEEO WIND SPEEO WINO GPEEO WINO BPEEO CATEGDRY I EATEGORY 2 CATEGORY 3 CATEGORY 4 CATEGORY 5 CATEQORY

$$
\begin{array}{r}
\text { OTRECTION } \\
\text { (DEGREES) } \\
0.000 \\
20.500
\end{array}
$$

0.00137025

0.00120022

0.00021004

0.00021004

0.00021004

0.00021004

$0.0002100 \mathrm{a}$

0.00038007

$0.000210 n$

$0.000 n a b 01$

0.00121004

0.00050010

0.00004001

0.00056010

0.00004001

0.00021004

0.00188034

0.00205037

0.00137025

0.00085015

0.00085015

0.001 .8034

0.00051009

0.00103019

0.00120022

0.00222040

0.00137025

0.00085015
0.00180034

0.00171031

0.00103019

0.00291053

0.00300056

0.00085015

0.00120022

0.00205037

0.00325059

0.00633114

0.00616111

0.00564102

0.00222040

0.00274049

0.00239043
0.00017003

0.00120022

0.00000000

0.00000000
0.00017003

0.00000000

0.00000000

0.00000000

0,00000000

0.00000000

0.00000000

0.00000000

0.00000000

0.00051009

0.00120022

0.00017003

0.00017003

0.00000000

0.00017003

0.00000000
0.00000000

0.00000000

0.00000000

0.00000000

0.00000000

0.00000000

0.00017003

0.00000000

0.00000000

0.00000000

0.00034006

0.00000000

0.00000000

0.00000000

0.00000000

0.00017003 
TABLE A-4d.

SEASON

STABLLITY CATEGORY

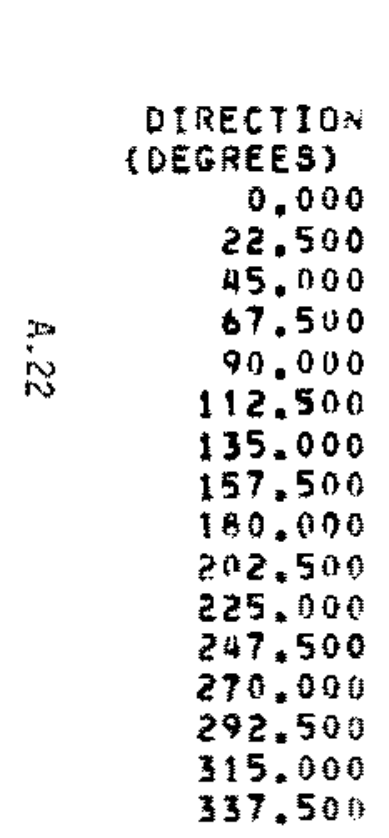

WWO SPEEO ND SPEED $(0.750 \mathrm{MPs})$

\subsection{3}

0.00059011

0.00547099

0.00059011

0.00718130

0.00059011

0.00513093

$0.00 \operatorname{sit} 7120$

0.00076014

0.00462083

0.00359065

0.0005901

0.00256046

0.00103019

0.00059011

0.00239043

0.00059011

0.00154028

0.09025015

0. 0ก007001

0.00274049

0.00496089

0.0004200 ?

$0.0004200 \mathrm{a}$

0.00530096

D. ก00azDoa

0.00410074

0.00325059

IND SPEED

WIND SEEED

VIND SPEED

CATECORY 5 CATEGORY

0.00110020

0.00300056

0.01180213

0.01163210

0.01077194

0.01026185

0.01317238

0.00462083

0.00103019

0.00154028

0.00342062

0.00616111

ก.01556201

0.01932348

0.00940170

0.00325059

0.00513093

0.00462043
CATEGORY A CATECORY 5 CATEGORY 6

0.00992179

0.01727311

0.00923166

0.00016111

0.01043188

0.00188034

0.00180034

0.00034006

0.00291053

0.02992540

0.10090820

0.07676663

0.01966355

0.00472157

0.00342062

0.00274049
0.00308056

0.00393071

0.00068012

0.00068012

0.00154028

0.00034006

0.00017003

0.00000000

0.00008012

0.02103379

0.06204135

0.01009182

0.00462083

0.00291053

0.00120022

0.00051009
0.00051004

0.00051009

0.00000000

0.00000000

0.00000000

0.00000000

0.00017003

0.00752136

0.03285592

0.00701126

0.00274044

0.00120022

0.00017003

0.00017003
0.00000000

0.00000000 
TABLE A $-4 e$.

- FREUUEACY OF OCCURRENCE DF HINO SPEED, DIRECTION AND GTABILITY -

SESON 1

STABILITY CATEGORY

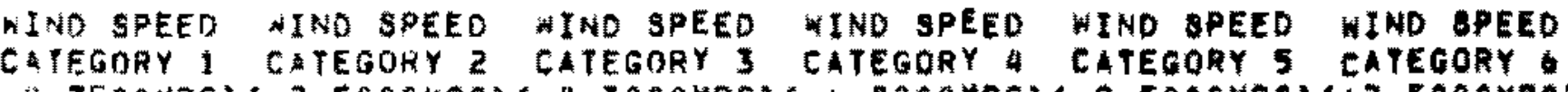

OINECTION

CATEORY 1

(1) CGREES)

0.000
22.500
45.000
67.500
90.000
112.500
135.000
157.500
180.000
202.500
225.000
247.500
270.000
292.500
315.000
337.500

0.01055010

0.00055010

0.00020004

0.00020004

0.00072013

0.00037007

0.00055010

0.07055010

0.06089016

Q.0100200nia

0.00055010

7. 00055010

0.00089010

0.00072013

0.00020004

0.00037047
0.00650117

$0.004450 B 0$

0.00616111

0.00308756

0.00393071

1. 0171031

v. 00205037

0.00065015

0.0027 a 049

0.07137025

0.00684123

7. 20769137

1). 00589160

0.00445080

0.0054709

0.00306056

\subsection{0}

0.00256046

0.00291053

0.00239043

0.00393071

0.00085015

0.00055015

0.00051009

12.00188034

0.00479086

0.02223401

0.04138746

0.01160213

0.00393071

0.00393071

0.00205037
0.00017003

0.00017003

0.00000000

0.00000000

0,00000000

0.00017003

0.00000000

0.00000000

0.00000000

0.00137025

0.00256046

0.00154026

0.00000000

0.00000000

0.00000000

0.00000000
0.00000000

0.00000000

0.00000000

0.00000000

0.00000000

0.00000000

0.00000000

0.00000000

0.00000000

0.00000000

0.00034006

0.00017003

0.00000000

0.00000000

0.00000000

0.00000000
0.00000000

0.00000000

0.00000000

0.00000000

0.00000000

0.00000000

0.00000000

0.00000000

0.00000000

0.00000000

0.00000000

0.00000000

0.00000000

0.00000000

0.00000000

0.00000000 
TABLE A-4f.

SEMSON 1

STABILITY CATEGORY

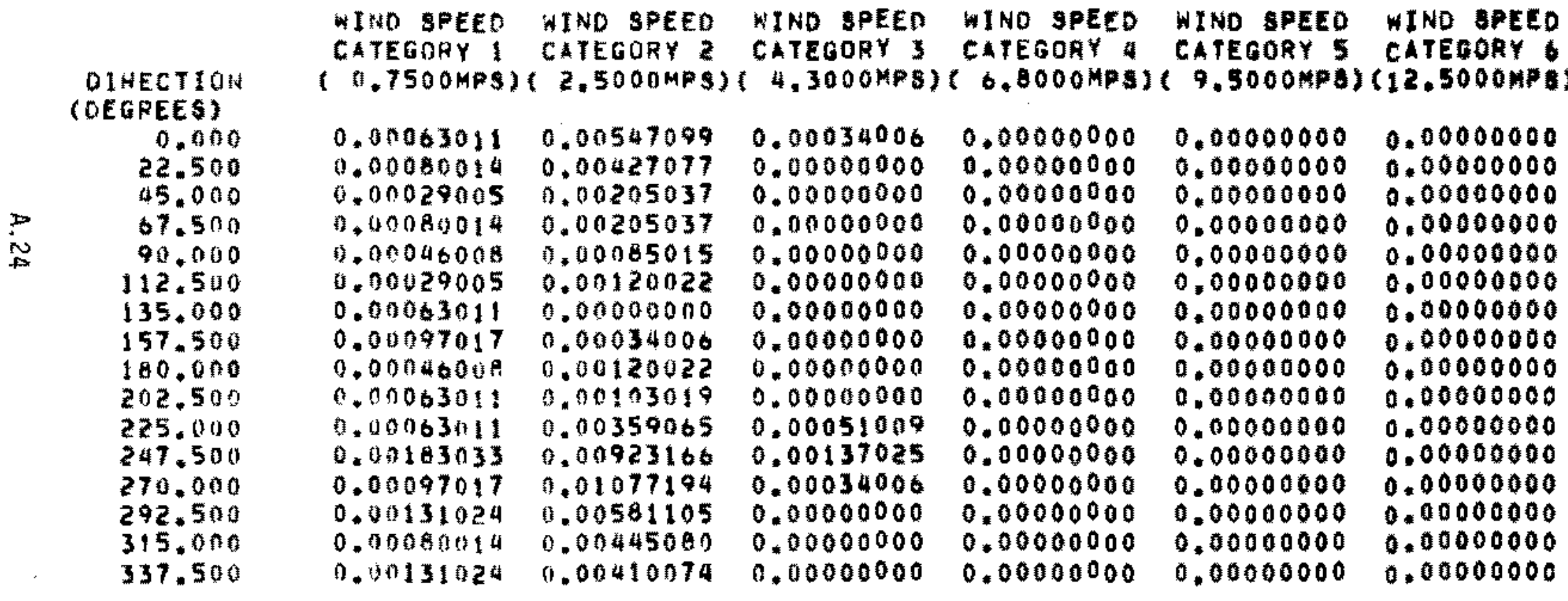


TABLE A-5a. La Polvadera Valley Meteorological Data (Source 5 in Table

- FREDUEVICY OF OCCURRENCE OF WIHD SPEED, OIRECTION AND STABILITY -

SEASON 1

STABLIYY CATEGOAY

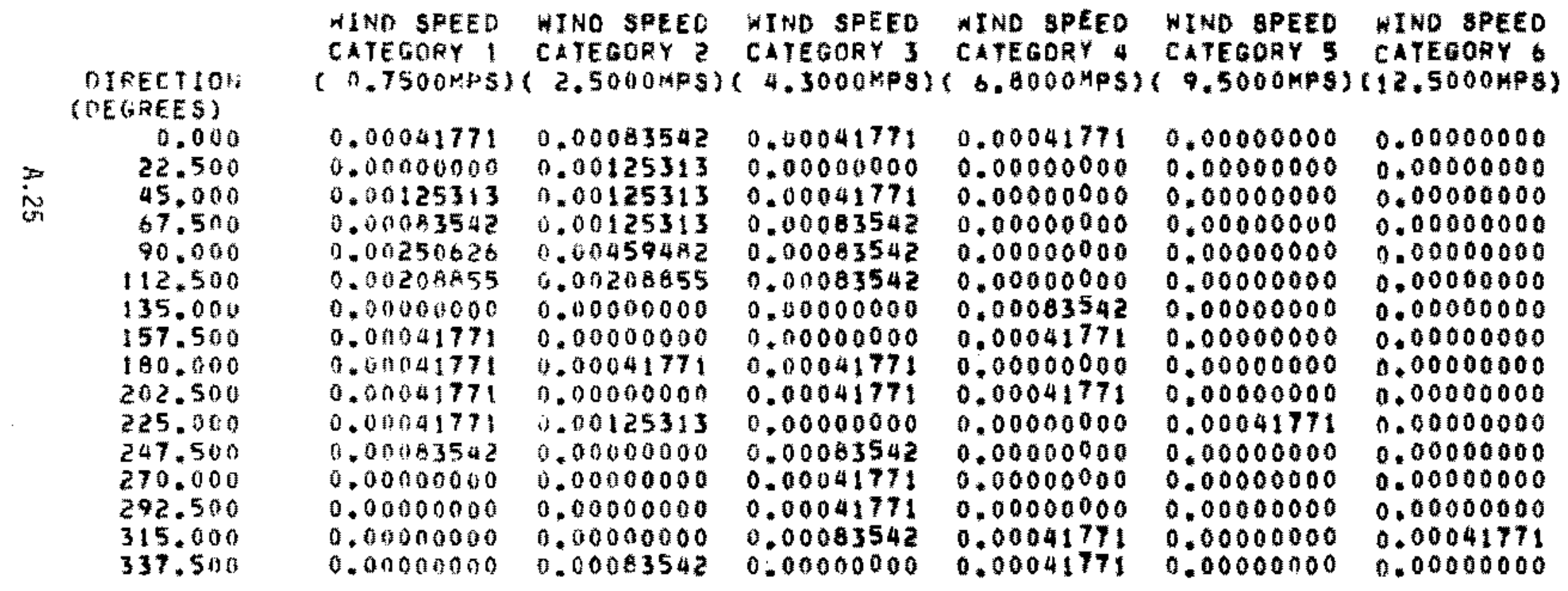


TABLE A-5b.

SEASOA

STABILITY CATEGORY 2

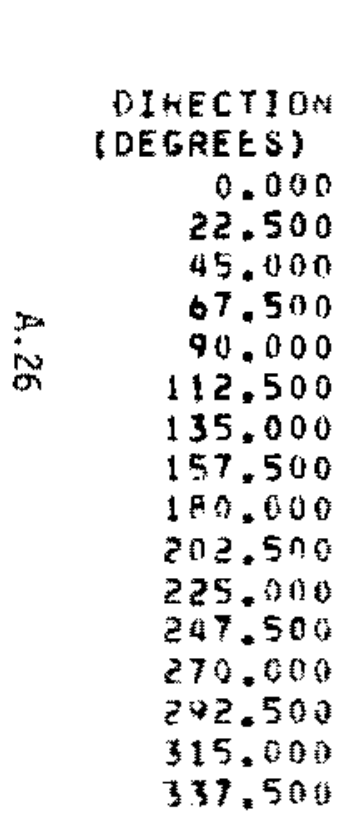

WIND SPEEO WIND SPEED WINT SPEEO CATEGORY GATEORY 2 CATEGORY 3 CATEOORY 4 CAYEGORY 5 CATEGORY

WIND SPEED

WINO SPEED WIND SPEED $(0.7500 \mathrm{MPS})(2.500 \mathrm{MPS})(4.3000 \mathrm{MPS})(0.8000 \mathrm{MP})(9.5000 \mathrm{MPS})(12.5000 \mathrm{MP})$

\subsection{4}

0.00083542

0.00250626

0.00167084

0.00000000

0.00000000

0.000417710 .00250626

0.00167084

0.00000000

0.00000000

0.000417710 .00208855

0.00167084

0.00000000

0.00000000

0.00292398

0.00000000

0.00083512

0.00292398

0.00334169

0.00033542

0.00000000

1. .00083542

0.00125313

0.00208855

0.00334169

0.00000000

0.00041771

0.00041771

0.00125313

0.00334169

0.00334169

0.00041771

0.00041771

0.00250626

0.00208555

0.00208855

0.00584795

0.00417711

0.00000000

0.0012513

0.00063542

0.00501253

0.00125313

0.0003542

0.00167084

0.00125313

0.00125313

0.00334169

0.00000000

0.00083542

1).00167034

0.00041771

0.01125313

0.00250626

U. 00125313

0.00083542

0.00041771

0.00125313

0.00125313

0.00000000

0.0012531

1..00167084

0.00125313

0.00125313

0.00000000

0.00000000

.00375940

0.00250626

0.00041771

0.00083542

0.00000000

0.00000000

0.00000000

0.00000000

0.00000000

0.00000000

0.00000000

0.00000000

0.00000000

0.00083542

0.00000000

0.00000000

0.00125313

0.00041771

0.00125313

0.0004177

0.00167084

0.00125313

0.0004177

0.00000000 
TABLE A-5c

- FREUUEZT OF OCCURRENCE OF WINO SPEED, OIRECTION ANO STABILITY

SEASON I

STABILITY CATEGIRY 3

WIND SPFEP WINO SPEED WIWD SPEED WINO SPEED WIND SPEEO WIND SPEED

CATFHORY LATFEORY Z CATEGORY 3 CATEGORY 4 CATEGORY 5 CATEGORY G

DIGECTON (DEGREES)

$$
\begin{array}{r}
0.000 \\
22.500
\end{array}
$$

45.000 67.500 90.000

112.500

135.000

157.500

130.000

202.500

225.000

247.500

270.050

292.500

315.000

(c.7500mps)

$9.5000 \mathrm{MPS})(12.5000 \mathrm{MP}$ )

0.00167044

0.00292398

0.00167084

0.00041771

0.00000000

0.00083542

0.00167084

0.00000000

1.00125313

1). 00250626

0.00083542

0.00063542

0.000183542

ก. $0029237 \%$

0.00083542

0.00334120

0. 60208555

0.00292398

$0.000835+2$

0.00141771

0.00041771

v. (b)

0.00125313

0.010167084

0.00083542

0.00206855

0.00208855

0.00000000

0.00000000

0.00000000

0.0012531

0.00375940

0.00751879

0.00000000

0.00000000

0.00000000

6. 4004177

0.00208855

0.00459482

0.00125313

0.00041771

0.00000000

0.045417\%1

0.00584795

0.00501253

*.0320655

0.00292308

0.00417711

$0.0033416 \%$

0.00167084

0.00167084

0.06017/1

0.00063542

0.00041771

0.00125313

0.00208855

0.00292398

0.00292398

0.00000000

0.00000000

0.00023542

n. 00000000

0.00000000

0.00083542

0.00000000

0.00000000

$0.0033416 \%$

0.00041771

0.00417711

0.00041771

.00000000

0.00459482

0.00167084

0.00000000

0.00000000

0.00501253

0.00292396

0.00000000

0.00041771

0.00167084

0.00041771

0.00167084

0.00000000

0.00292390

0.0 i) 13542

$0.00125 \$ 13$

a. 60334169

0.00242398

0.00167084

0.00000000

0.00000000

0.00000000

.00083542

0.00000000

$0,00000000 \quad 0.00041771$ 
TABLE A-5d.

SEAON 1

STABILITY CATEGORY 4

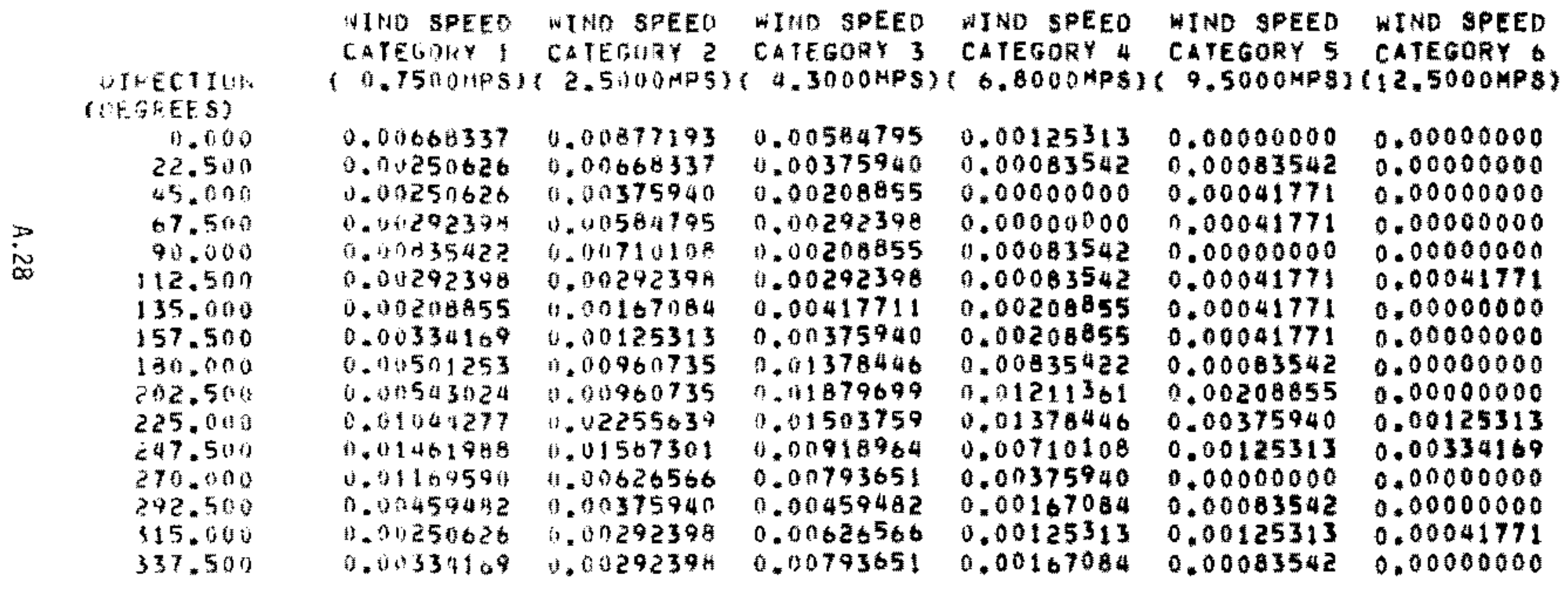


TABLE A-5e.

- FREDIENCY UF DCCURRENCE OF WIWO SPEEO, OIRECTION AND STABILITY -

$$
\text { SE SON : }
$$

STABLITY CAIEGORY 5

\begin{tabular}{|c|c|c|c|c|c|}
\hline $\begin{array}{l}\text { WINO SPEED } \\
\text { CATEORYY } 1 \\
0.7500 \text { HPS) }\end{array}$ & $\begin{array}{l}\text { HIND SPEED } \\
\text { CIEG(TRY } \\
2.50004 P S)\end{array}$ & $\begin{array}{l}\text { WO SPEED } \\
\text { COEGORY } 3 \\
4.3000 \mathrm{HPS})\end{array}$ & $\begin{array}{l}\text { INO SPEEO } \\
\text { CTEGORY } \\
6.8000 M P S Y\end{array}$ & $\begin{array}{l}\text { HND SPEED } \\
\text { CATEGORY } \\
\text { 9.500QNPS }\end{array}$ & $\begin{array}{l}\text { NINO SPEEO } \\
\text { CATEORY } \\
12.5000 M P S)\end{array}$ \\
\hline $\begin{array}{l}0.00125313 \\
0.00000000 \\
0.00167084 \\
0.00041771 \\
0.00334169 \\
0.00353542 \\
0.00137542 \\
0.00268555 \\
0.00250626 \\
.0114711 \\
0.00334164 \\
0.00026500 \\
0.00584795 \\
0.00208855 \\
0.00125313 \\
0.00083542\end{array}$ & $\begin{array}{l}0.00250626 \\
0.00125313 \\
0.00167084 \\
0.00208855 \\
0.00125313 \\
0.00250826 \\
0.00167084 \\
0.00083542 \\
0.00125313 \\
0.00626566 \\
0.01712614 \\
0.01044277 \\
0.00208855 \\
0.00083542 \\
0.00041771 \\
0.00041771\end{array}$ & $\begin{array}{l}0.00125313 \\
0.00041771 \\
0.00041771 \\
0.00000000 \\
0.00000000 \\
0.00083542 \\
0.00041771 \\
0.00167084 \\
0.00208555 \\
0.01002506 \\
0.00751879 \\
0.00334169 \\
0.00041771 \\
0.00000000 \\
0.00041771 \\
0.00000000\end{array}$ & $\begin{array}{l}0.00041771 \\
0.00000000 \\
0.00041771 \\
0.00000000 \\
0.00000000 \\
0.00000000 \\
0.00041771 \\
0.00000000 \\
0.00208555 \\
0.00167084 \\
0.00041771 \\
0.00041771 \\
0.00041771 \\
0.00083542 \\
0.00000000 \\
0.00000000\end{array}$ & $\begin{array}{l}0.00000000 \\
0.00000000 \\
0.00000000 \\
0.00000000 \\
0.00000000 \\
0.00000000 \\
0.00000000 \\
0.00000000 \\
0.00000000 \\
0.00041771 \\
0.00041771 \\
0.00041771 \\
0.00000000 \\
0.00000000 \\
0.00000000 \\
0.00000000\end{array}$ & $\begin{array}{l}0.00000000 \\
0.00000000 \\
0.00000000 \\
0.00000000 \\
0.00000000 \\
0.00000000 \\
0.00000000 \\
0.00000000 \\
0.00041771 \\
0.00000000 \\
0.00000000 \\
0.00000000 \\
0.00000000 \\
0.00000000 \\
0.00000000 \\
0.00000000\end{array}$ \\
\hline
\end{tabular}

DTFECTION (OEGREES)

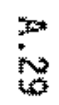

$$
\begin{array}{r}
0.000 \\
22.500 \\
45.000 \\
87.500 \\
90.000 \\
112.500 \\
135.000 \\
157.500 \\
160.000 \\
202.500 \\
225.000 \\
247.500 \\
270.060 \\
292.500 \\
315.000 \\
337.500
\end{array}
$$

0.00250626
0.00125313
0.00107084
0.00208855
0.00125313
0.00250026
0.00167084
0.00083542
0.00125313
0.00026566
0.01712614
0.0104427
0.00208855
0.00083542
0.00041771
0.00041771

0.00000000
.0004177 00000000

0.00000000

.00000000

.0020855

0.00000000 
TABLE Am $5 \mathrm{f}$.

SEASON 1

STAAILITY CATEGORY O

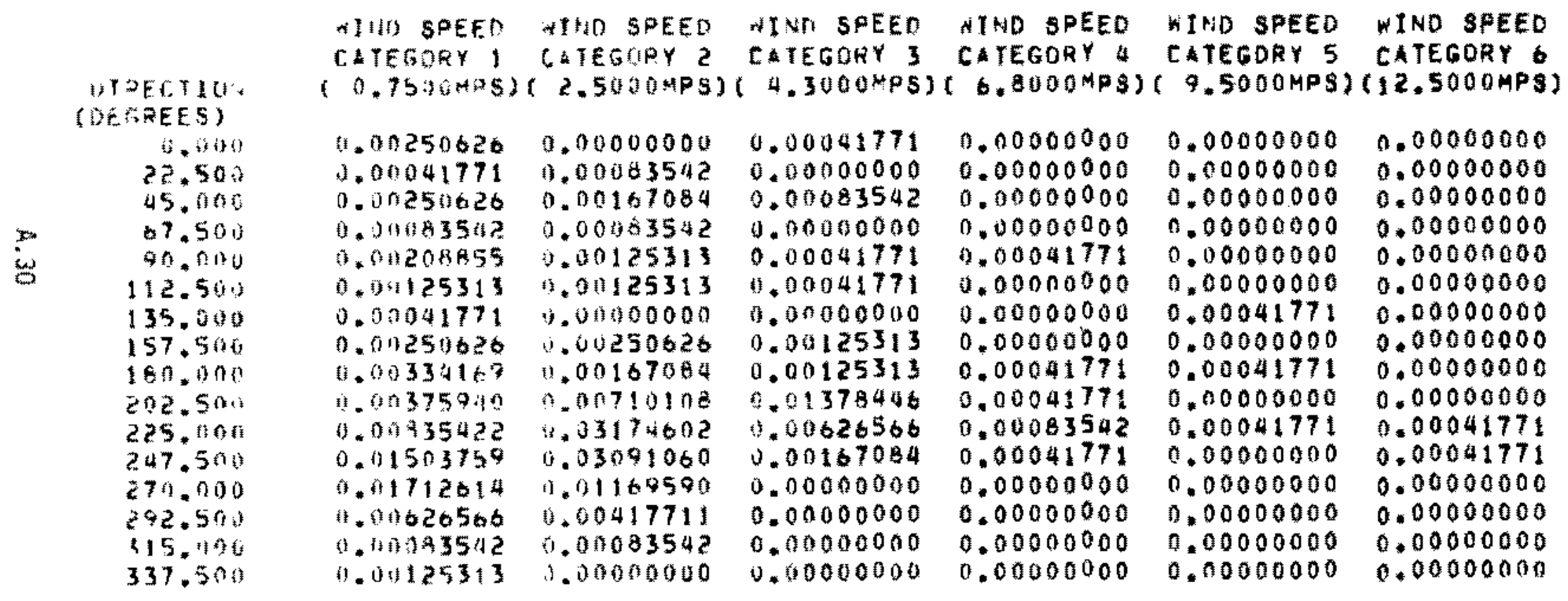


TAbLE A.6a. Gallup Meteorologfcal Data (5ource 6 in Table C.1)

SEASOH 1

\section{STAFILITY CATEGORY 1}

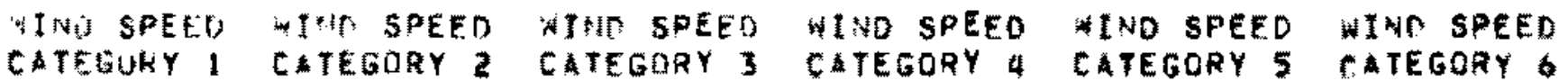

DISETIO: (DEGFES)

$\sum_{-\infty}^{22.500}$

67.500

90. 000

112.510

135.000

157.500

160.001

212.500

225.000

277.500

270.000

292.500

315.000

337.500

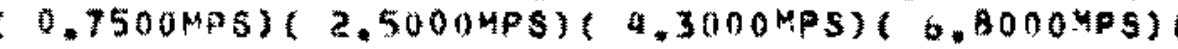

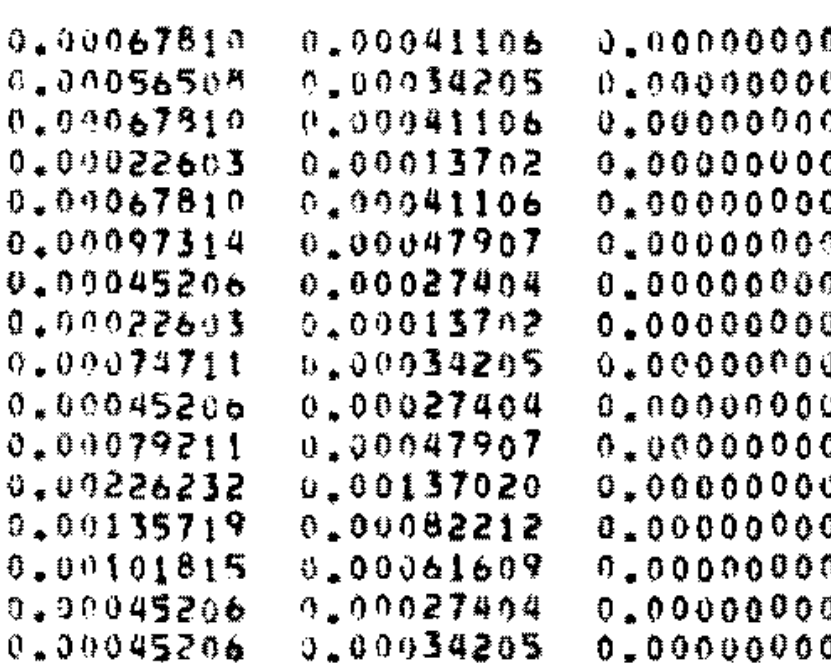

0.00000000

0.00000000

0.00000000

0.00000000

0.00000000

0.00000000

0.00000000

0.00000000

0.00000000

0.00000000

0.00000000

0.00000000

0.00000000

0.00000000

0.00000000

0.00000000

0.00000000

0.0000 .0000

0.00000000

0.00000000

0.00000000

0.00000000

0.00000000

0.00000000

0.00000000

0.00000000

0.00000000

0.00000000

0.00000000

0.00000000

0.00000000

0.00000000
0.00000000

0.00000000

0.00000000

0.00000000

0.00000000

0.00000000

0.00000000

0.00000000

0.00000000

0.00000000

0.00000000

0.00000000

0.00000000

0.00000000

0.00000000 
TABLE A.6b. (Contd).

\section{SEASON 1}

\section{STABILITY CATEGORY Z}

OIRECTION
(DECREES)
0.000
22.500
45.000
67.500
90.000
112.500
135.000
157.500
120.000
202.500
225.000
247.500
270.000
272.500
315.000
337.500

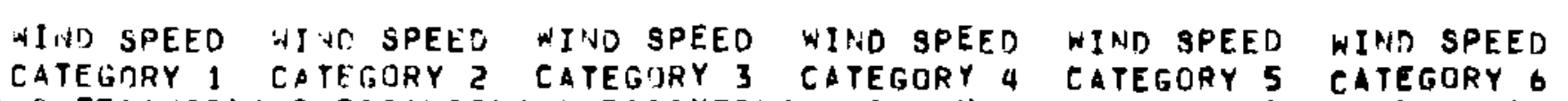
$(0.7500 \mathrm{MPS})(2.5000 \mathrm{MPS})(4.300 \mathrm{MPPS})(6.8000 \mathrm{MPS})(9.5000 \mathrm{MPS})(12.5000 \mathrm{MPS})$

$\begin{array}{ll}0.00467767 & 0.00212330 \\ 0.00172025 & 0.00075311 \\ 0.00378354 & 0.00157523 \\ 0.00200834 & 0.00109616 \\ 0.00240834 & 0.00109616 \\ 0.00082612 & 0.00041106 \\ 0.00158223 & 0.00068510 \\ 0.01172025 & 0.00075311 \\ 0.00247735 & 0.00123318 \\ 0.00240734 & 0.00089013 \\ 0.00302743 & 0.00150722 \\ 0.00598486 & 0.00267138 \\ 0.00646692 & 0.00301443 \\ 0.00295842 & 0.00137020 \\ 0.00399057 & 0.00178125 \\ 0.00192628 & 0.00075311\end{array}$

$0.0008221 ? 0.00000000$ $0.00054808 \quad 0.00000000$ 0.00075311 0.00075311 0.00075311 0.00027404 0.00041106 0.00034205 0.00095914 0.00102715 0.00198628 0.00246635 0.00226032 0.00123318 0.00082212 0.00000000 0.00000000 0.00000000 0.00000000 0.00000000 0.00000000 0.00000000 0.00000000 0.00000000 0.00000000 0.00000000 0.00000000 0.00000000

0.00082212

0.00000000

0.00000000 0.00000000 0.00000000 0.00000000 0.00000000 0.00000000 0.00000000 0.00000000 0.00000000 0.00000000 0.00000000 0.00000000 0.00000000 0.00000000 0.00000000

0.00000000 0.00000000 0.00000000 0.00000000 0.00000000 0.00000000 0.00000000 0.00000000 0.00000000 0.00000000 0.00000000 0.00000000 0.00000000 0.00000000 0.00000000 0.00000000 
TABLE A, 6C. (Contd)

SEASON 1

STABILITY CATEGOAY

DIECTION (IEGRES)

is

$$
\begin{array}{r}
0.000 \\
22.500 \\
45.000 \\
67.500 \\
90.000 \\
112.500 \\
135.000 \\
157.500 \\
180.000 \\
202.500 \\
225.000 \\
247.500 \\
270.000 \\
292.500 \\
315.000 \\
337.500
\end{array}
$$

MIT SPEE UIVE SPEED CA TELORY I CATEGORY 2

*INO SOEEO CATEGORY 3

NINO SPEED CATEGORY

HIND SPEEO CATEGORY 5

MIND BPEED $(0.7500 \mathrm{HPS})(2.5000 \mathrm{MPS})(4.3000 \mathrm{HP})($

$$
\begin{aligned}
& 0.00098914 \\
& 0.00097314 \\
& 0.00130019 \\
& 0.00132919 \\
& 0.00059405 \\
& 0.00022003 \\
& 0.00017002 \\
& 0.00022603 \\
& 0.00070710 \\
& 0.00484012 \\
& 0.00190221 \\
& 0.00223332 \\
& 0.00213230 \\
& 0.00110310 \\
& 0.00053708 \\
& 0.00042406
\end{aligned}
$$
0.00239734 C. 00212330 0.00315145 0.00321946 0.00143821 0.00054808 0.00041106 0.0005408 0.00171224 0.00205520 0.00335648 0.00541177 0.00493270 0.00267138

0.00246635 0.00150722 0.00164423 0.00376754 0.00205529 0.00075311 0.00089013 0.00274039 0.00383655 0.00657594 0.00972739 0.00602786 0.00328847 0.00130119 i). 00102715 0.00095914 0.00054808

0.00020503 0.00020503 0.00027404 0.00020503 0.00020503 0.00006301 0.00013702 0.00006001 0.0007531 0.00171224 0.00411059 0.00452165 0.00315195 0.00109616 0.001301190 .0004707
0.00000000 0.00000000 0.00006801 0.00000000 0.00000000 0.00006801 0.00000000 0.00027404 0.00034205 0.00184926 0.00246635 0.00020503 0.00006801 0.00006001 0.00054608
0.00000000 0.00000000 0.00000000 0.00000000 0.00000000 0.00000000 0.00000000 0.00000000 0.00000000 0.00027404 0.00075311 0.00041106 0.00006801 0.00000000 0.00000000 0.00000000 
TABLE A.6d. (conta)

SEASON 1

STABILITY CATESORY

WHO SPEFD UIL SPEED WINO SPEED WINO GPEED WIND SPEED WIND SPEED CATEGORY I CATEGDAY ? CATEGDRY 3 CATEGOAY 4 CATEGORY 5 CATEGORY

DIAECTIOH (TECREES)

0.0 in

is
CAEGORY L CA
$0.7500 \mathrm{MAS}) !$

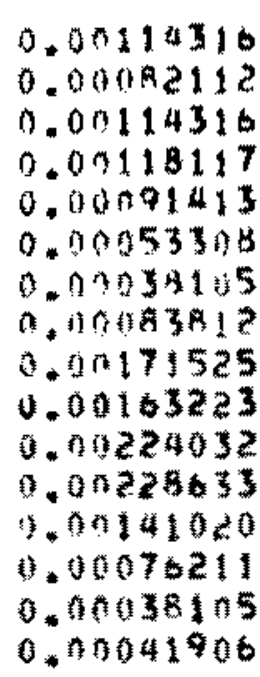

1). 00205529

0.00130119

0.00205529

0. 01212330

0.00164423

0.00095914

0.00064510

0.0150722

0.00308244

0.00274039

0.00383655

0.00411059

6. 10253436

0. $n 0137020$

0.00068510

0.00075311
0.00417660

0.00349350

0.00335648

0.00589084

$0.00465 \% 67$

0.00143021

0.00150722

0.00328047

0.01013845

0.01287884

0.02013988

0.01815359

0.00965938

0.00342549

0.00246635

0.00150722
0.00342549

0.00260337

0.00239734

0.00335646

0.00294542

$0.00082 z 12$

0.00137020

0.00304244

0.0070501

0.01096057

0.02938820

0.03247064

0.01548121

0.00623389

0.00363052

0.00123318
0.00020503

0.00020503

0.00006801

0.00047907

0.00068510

0.00006801

7.00027404

0.00075311

0.00102715

0.00280840

0.00863123

0.01294685

0.00445264

0.00164423

0.00054806

0.00034205
0.00013702

0.00006001

0.00000000

0.00006801

0.00006801

0.00006801

0.00006801

0.00020503

0.00034205

0.00068510

0.00328847

0.00445264

0.00116417

0.00020503

0.00013702

0.00000000 
TABLE A.6e. (contd)

SEASON 1

STABILITY CATEGORY $\$$

DIRECION (DEGRES)

$$
0.000
$$

22.500

is $\quad 05.000$

$\$ 0.000$

112.500

135.000

$\$ 57.500$

180.000

202.500

225.000

247.500

270.000

292.500

315.000

337.500

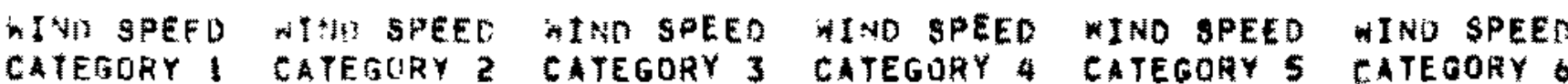

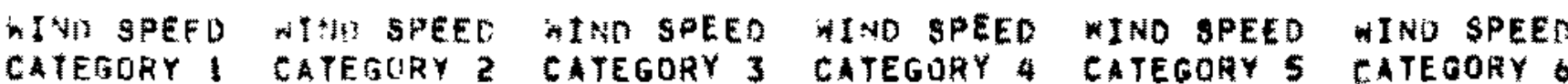
$(0.7500 \mathrm{MPS})(2.5000 \mathrm{MPS})(4.3000 \mathrm{MPS})(0.8000 \mathrm{MPS})(9.5000 \mathrm{MPS})(12.5000 \mathrm{MP} 5)$

0.00000000

0.07000000

0.00102715

0.00302244

0.02300000

0.00191927

0.00239734

ก.01184026

0.00205529

0.00000000

0.00000000

0.00000000

0.00000000

0.00000000

0.00157523

0.00205529

0.00000000

0.00000000

0.00212330

0.00178125

00000000

0.00000000

0.00000010

0.00157523

0.00089013

.00000000

0.00000000

0.00000000

0.00232933

0.00075311

0.00000000

0.00000000

0.00000000

0.00191627

- 00000000

0.00171224

0.00000000

0.00424761

0.00000000

0.00301443

0.00780912

0.00070000

0.00000000

0.00774111

0.00342549

. $0 n 300000$

0.09404158

0.00000000

0.00993342

0.00000000

0.00000000

0.00000000

0.00000000

0.00000000

.00000000

0.00767210

(2)

0.00000000

19182

0356251

0.00000000

0.00000000

0.00000000

0.00008510

0.0020552

0.00000000

$0.00000000 \quad 0.00000000$

$0.00000000 \quad 0.00000000$
0.00000000

0.00000000

0.00000000

0.00000000

0.00000000

0.00000000

0.00000000

0.00000000

0.00000000

0.00000000

0.00000000

0.00000000

0.00000000

0.00000000

0.00000000

0.00000000 
IABLE A.6f. (Contd)

\section{SEASON 1}

\section{STABILITY CATEGURY 6}

DIRECTION (DEGREES)

$$
0.000
$$

$$
45.000
$$$$
22.500
$$

$$
07.500
$$

90.000

112.500

135.000

157.500

100.000

202.500

225.000

247.500

270.000

292.500

315.0100

337.500

WINI SPEED CATEGORY

DI INU SPEED

CATEGORY

WITO SPEED

WITD SPEED

WIND SPEED WIND SPEED ( $0.7500 \mathrm{NPS})($

0.01354374

0.01387198

0.02741592

0.02090499

0.02958123

0.01739549

0.01427004

0.01777954

0.03213159

0.01706644

0.02227518

0.02838906

ก. 01583226

0.00468767

0.00338548

0.013390656

\subsection{1} 0. 00356251

(1. 00712402

0.00541177

0.00726104

0.00431562

0.00349350

0.00458966

0.00767210

0.00431562

0.00568581

0.00746707

0.00390456

0.00123318

0.00089013

0.00102715
0.00000000

0.00000000

0.00000000

0.00000000

0.00000000

0.00000000

0.00000000

0.00000000

0.00000000

0.00000000

0.00000000

0.00000000

0.00000000

0.00000000

0.00000000

0.00000000
CATEGORY 4

\section{CATEGORY 5 CATEGORY B}

0.00000000

0.00000000

0.00000000

0.00000000

0.00000000

0.00000000

0.00000000

0.00000000

0.00000000

0.00000000

0.00000000

0.00000000

0.00000000

0.00000000

0.00000000

0.00000000
0.00000000

0.00000000

0.00000000

0.00000000

0.00000000

0.00000000

0.00000000

0.00000000

0.00000000

0.00000000

0.00000000

0.00000000

0.00000000

0.00000000

0.00000000
0.00000000
0.00000000

0.00000000

0.00000000

0.00000000

0.00000000

0.00000000

0.00000000

0.00000000

0.00000000

0.00000000

0.00000000

0.00000000

0.00000000

0.00000000

0.00000000

0.00000000 
TABLE Aa. Phllips site Meteorological Data (Source 7 in Table $6-1$ )

- FEDUENCY DF UCCURRENCE OF WIAD SREED, DIRECTION ANO STAILITY

\section{SEASON 1}

\section{STABILITY CATEGHY 1}

DIFECTIOU (DEGREES)

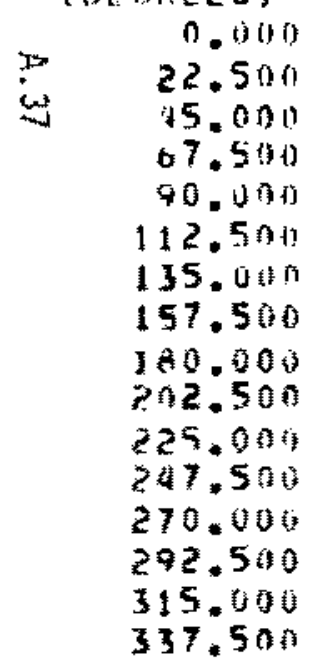

\section{STABILITY CATEGUAY L}

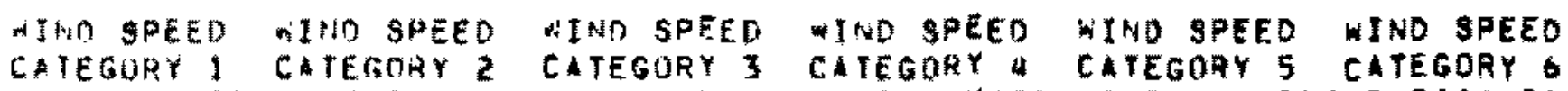

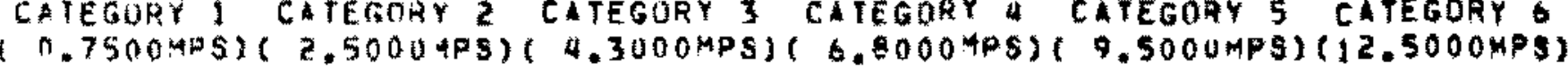

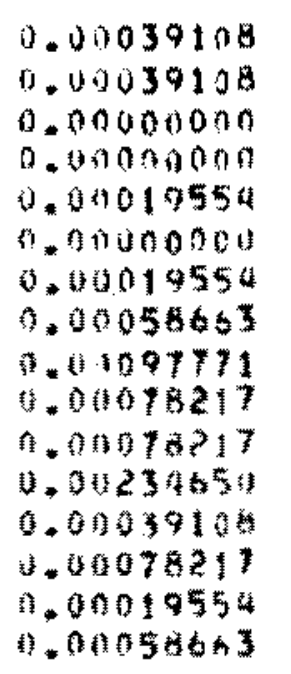

\begin{tabular}{|c|c|}
\hline 1.00000000 & $\Rightarrow 000$ \\
\hline$) .00000000$ & 0.00000000 \\
\hline $\begin{array}{r}.10000000 \\
.0000000\end{array}$ & \\
\hline Moonuono & \\
\hline $0.0001 \$ 554$ & \\
\hline & \\
\hline 10.0 & 00 \\
\hline 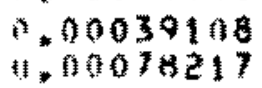 & \\
\hline 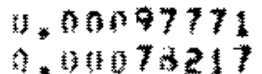 & \\
\hline 001136079 & 0.00000000 \\
\hline 1.000195 & 0.0000000 \\
\hline 0.1 & 0.0000000 \\
\hline 00195 & 0.0000000 \\
\hline
\end{tabular}

0.00000000 0.00000000 0.00000000 0.00000000 0.00000000 0.00000000 0.00000000 0.00000000 0.00000000 0.00000000 0.00000000 0.00000000 0.00000000 0.00000000 0.00000000 0.00000000
0.00000000

0.00000000

0.00000000

0.00000000

0.00000000

0.00000000

0.00000000

0.00000000

0.00000000

0.00000000

0.00000000

0.100000000

0.00000000

0.00000000

0.00000000

0.00000000
0.00000000

0.00000000

0.00000000

0.00000000

0.00000000

0.00000000

0.00000000

0.00000000

0.00000000

0.00000000

0.00000000

0.00000000

0.00000000

0.00000000

0.00000000

0.00000000 
TABLE $A-7 b$.

SEASUN I

STHBILITY CATEGORY

ULECTIOH (DEEREES)

0.000

$$
22.500
$$

45.000
67.500

40.000

112.5010

135.000

157.500

180.000

202.500

225.000

247.500

270.000

292.500

315.000

337,500

\begin{abstract}
HINU SPEEO
CATEGURY

CATECRRY

WIHD SPEEO

CATEGORY 3

WIND SPEED

CATECOAY a
\end{abstract}

( $0.7500 \mathrm{MPS})(2.5000 \mathrm{MPS})(4.3000 \mathrm{MPS})(0.0000 \mathrm{MPS})($

0.00039108

0.00058663

$0.0003910 \mathrm{~s}$

0.00000000

0.00000010

0.01019554

0.00058603

0.00175988

0.00234650

0.00136079

0.00078217

0.00097771

0.00055663

0.00000000

0.10039108

0.00058663

0.00019554

0.00000000

0.00019554

0.00039108

0.00195542

0.00215096

0.00079217

0.01009771

0.00175988

0.00097771

0.00117325

0.00117325

0.00097771

$0.00078217 \quad 0.00254204$

U. 01078217
0.00019554

0.00019554

0.00000000

4. 10000000

0.00000000

0.00000000

0.00019554

0.00000000

1. 00039108

0.00039100

0.00019554

0.00019554

0.00000000

3.00000000

i). 00000000
0.00000000

0.00000000

0.00000000

0.00000000

0.00000000

0.00000000

0.00000000

0.00000000

0.00000000

0.00000000

0.00019554

0.00000000

0.00000000

0.00000000

0.00000000

0.00000000
WIND SPEED

TTO ( $9.5000 \mathrm{mps})(12.5000 \mathrm{MP})$

0.00000000

0.00000000

0.00000000

0.00000000

0.00000000

0.00000000

0.00000000

0.00000000

0.00005000

0.00000000

0.06000000

0.00000000

0.00000000

0.00000000

0.00000000

0.00000000
0.00000000

0.00000000

0.00000000

0.00000000

0.00000000

0.00000000

0.00000000

0.00000000

0.00000000

0.00000000

0.00000000

0.00000000

0.00000000

0.00000000

0.00000000

0.00000000 
TABLE A-Y.

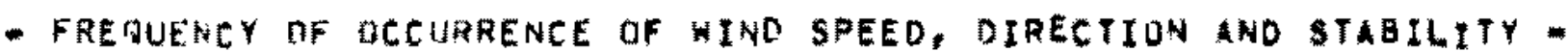

SEASON I

SIABILITY CATEGORY

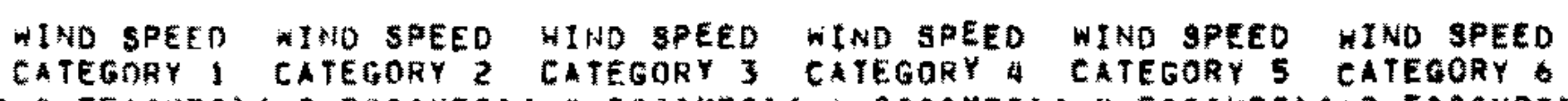

PIFECTION (0.750OMNS)(2.50DOHP\$3) 4.3000MPS)(6.8000MPS)(9.5000MP5)(12.5000MPS)

(DEGREES)
0.000
22.500
45.000
67.500
90.000
112.500
135.000
157.500
130.000
202.500
225.000
207.500
270.000
292.500
315.000
337.500

0.00019554
0.00058663
0.00000100
0.00019554
0.00119554
0.00078217
0.00117325
0.00234650
0.00449746
0.00195547
0.07195517
0.00136579
0.00332421
0.00156433
0.00195542
0.001139108

0.00215096
0.00039108
0.00097771
0.00019554
0.00019554
0.00078217
0.00039108
0.00234650
0.00391083
0.00332421
0.00175948
0.00195542
0.00371529
0.00410638
0.00215096
0.00215096

0.00117325

0.00000000

0.00000000

0.00019554

0.00000000

0.00000000

0.00000000

0.00000000

0.00000000

0.00000000

0.00000000

0.50000000

0.00000000

0.00000000

0.00000000

$0.0000000 n$

0.00000000

0.00000000

0.00000000

0.00000000

Q.00nonoto

0.00000000

0.00000000

0.00000000

0.00000000

0.00000000

0.00000000

.00070217

0.00000000

0.00000000

0.00078217

0.00019554

0.00000000

0.00058663

0.00000000

0.00312867

0.00078217

0.00000000

0.00030108

0.00000000

0.00000000

.00000000

0.00000000

0.00000000

0.00000000

0.00000000

0.00000000

0.00000000

0.00000000

0.00000000

0.00000000

0.00000000

0.00000000

0.00195542

0.00000000

0.00000000

0.00000000

0.00000000

0.00000000 
TABLE A-7d.

\section{SEASON I}

STABILITY CATEGORY 4

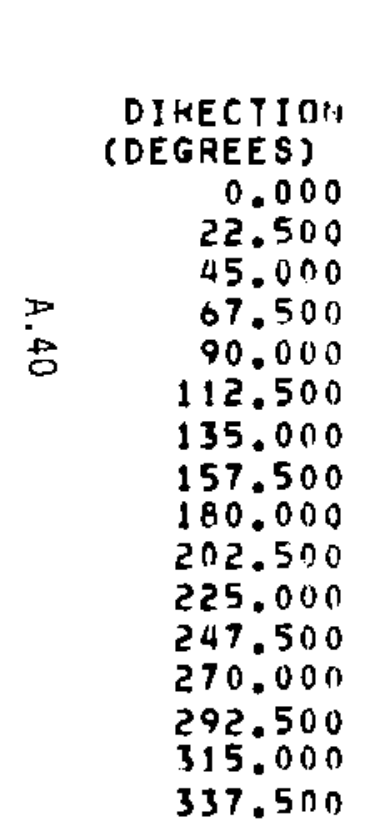

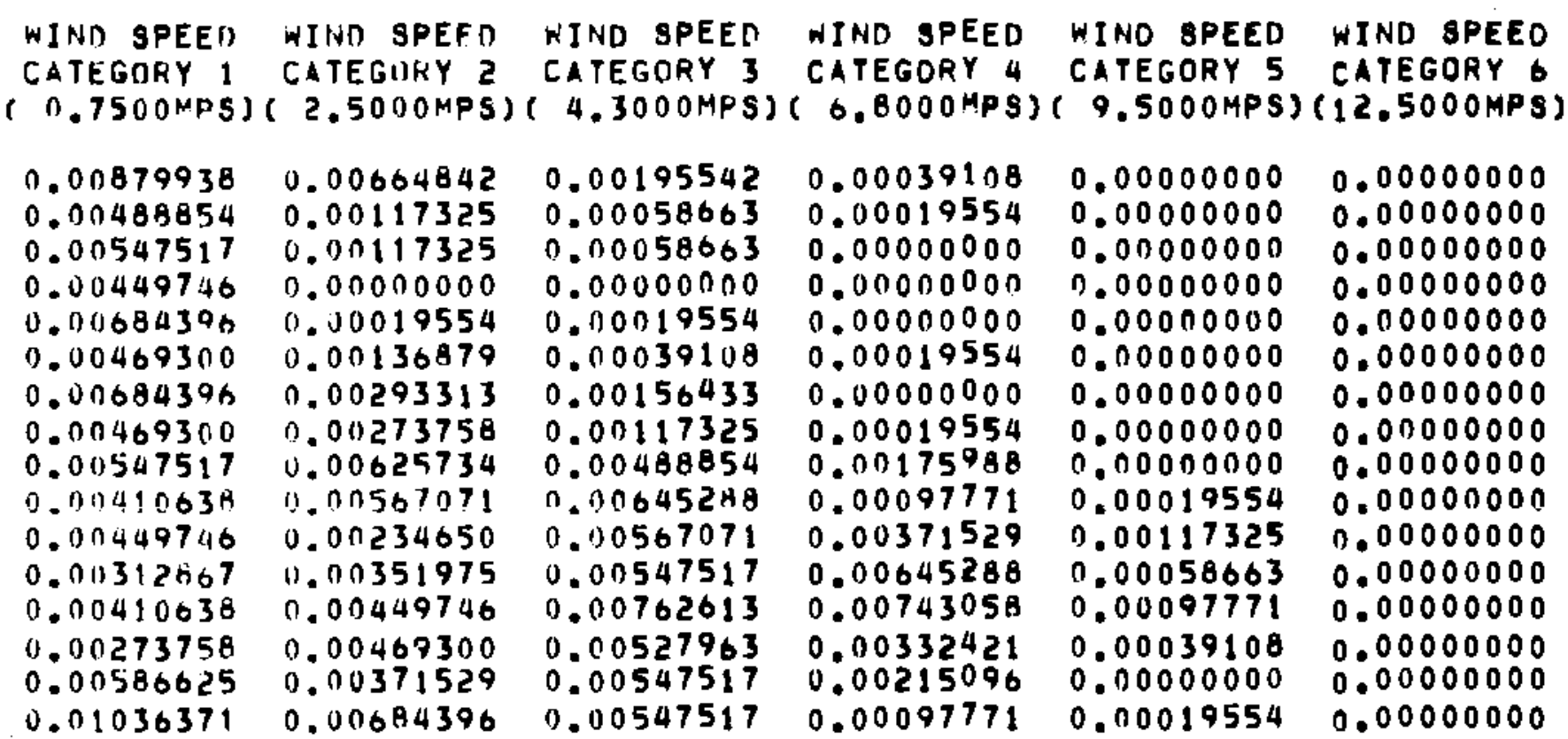


IABLE A-7e.

- FREDUENCF OF DCCURRENCE OF WIND SPEED, DIRECTION AND STABILITY -

SEASOH: 1

STABILTY CATEGORY 5

WIVI SPEED NIND SPEED WIND SPEED WINO SPEEO NIND SPEEO WIND SPEEO CATEGORY 1 CATEGURY 2 CATEGORY 3 CATEGORY 4 CATEGQRY 5 CATEGOAY

$$
\begin{array}{r}
\text { (OEGREES) } \\
\$ \quad 0.00 \\
\$ \quad 22.50
\end{array}
$$

IRECTION

$(0.750$ MPPS $)($

\subsection{5}

0.01857640

0.01251467

0.0111458

0.01564334

0.00840929

0.00921275

0.00762613

0.00762013

0.013371529

0,0050 的 0 \%

0.01449746

0.00702613

0.00547517

0.01368792

0.01916309

\subsection{5}

0.00606179

0.00234650

0.00117325

0.00254204

0. 01949746

0.00506025

0.00391083

0.00645288

$0.007^{\mathrm{A}} 2167$

4.00449746

1). 00508400

0.009191146

0.90469300

0.00645288

0.01603442
( $4.3000 \mathrm{MPS})$

\subsection{1}

0.00097771

9,00078217

0.00058663

0.00058063

0.00234850

0.00136879

Q. 00136879

0.00508408

0.00743058

0.07406854

0.00527963

0.01075470

0.00527963

0.00408854

0.00684396
0.00097171

0.00019554

0.00019554

0.00078217

0.00000000

0.04058663

0.00019554

0.00039108

0.00273758

0.00449746

0.00293313

0,00723504

0.01134142

0.00430192

0.00567071

0.00215096
0.00000000

0.00000000

0.00000000

0.00000000

0.00000000

0.00000000

0.00019554

0.00019554

0.00019554

0,00079217

0.00039108

0.00175988

0.00332421

0.00215096

0.00117325

0.00019554
0.00000000

0.00000000

0.00000000

0.00000000

0.00000000

0.00000000

0.00000000

0.00000000

0.00000000

0.00000000

0.00000000

0.00000000

0.00000000

0.00019554

0.00000000

0.00000000 
TABLE A-7f.

\section{SEABON I}

\section{STABILITY CATEGORY O}

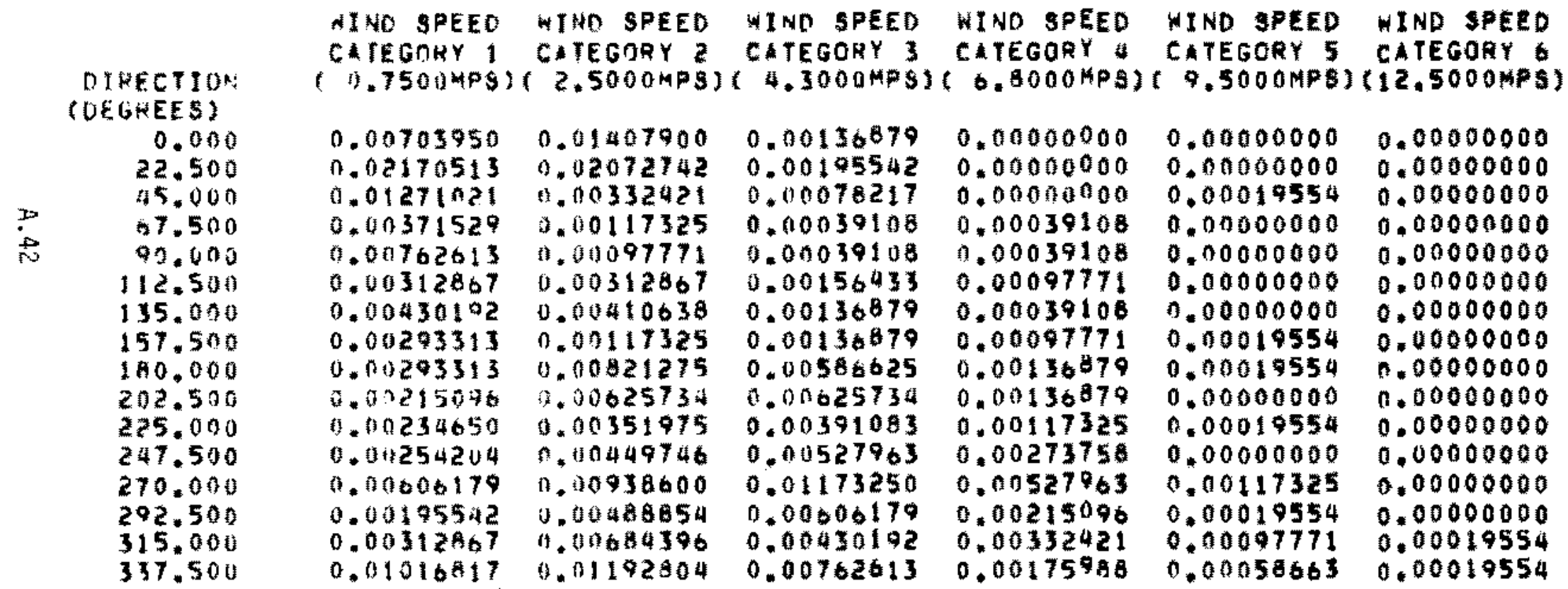


TABLE A-8a, Nose Rock Meteorological Data (Source 8 in Table C-1)

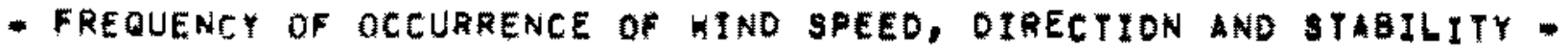

SEASON 1

STAOLITY CATEGOAY 1

OIRECTION
(OEGREES)
0.000
22.500
45.000
67.500
90.700
112.500
135.000
157.500
180.000
202.500
225.000
247.500
270.000
292.500
315.000
337.500

WNO SPEED HIND SPEED WIND SPEED WIND SPEEO WIND SPEED WIND SPEED
CATEGORY I CATEGORYZ CATECOAY S CATEGORY CATEGORY 5 CATEGORY $(0.5000 \mathrm{MPS})(1.5000 \mathrm{MPS})(5.0000 \mathrm{MPS})(0.0000 \mathrm{MP})(10.0000 \mathrm{MP} 8)(12.5000 \mathrm{mP})$

$\begin{array}{llllll}0.00000000 & 0.00015480 & 0.00030960 & 0.00000000 & 0.00000000 & 0.00000000 \\ 0.00000000 & 0.00000000 & 0.00015480 & 0.00000000 & 0.00000000 & 0.00000000 \\ 0.00000000 & 0.00000000 & 0.00030900 & 0.00000000 & 0.00000000 & 0.00000000 \\ 0.00000000 & 0.00015480 & 0.00015480 & 0.00000000 & 0.00000000 & 0.00000000 \\ 0.00000000 & 0.00000000 & 0.00061920 & 0.00000000 & 0.00000000 & 0.00000000 \\ 0.000000400 & 0.00000000 & 0.00030960 & 0.00000000 & 0.00000000 & 0.00000000 \\ 0.00015400 & 0.00015480 & 0.00000000 & 0.00000000 & 0.00000000 & 0.00000000 \\ 0.00000000 & 0.00015480 & 0.00000000 & 0.00000000 & 0.00000000 & 0.00000000 \\ 0.00000000 & 0.00015480 & 0.00015480 & 0.00000000 & 0.00000000 & 0.00000000 \\ 0.00015480 & 0.00000000 & 0.00015480 & 0.00000000 & 0.00000000 & 0.00000000 \\ 1.00000000 & 0.00015480 & 0.00000000 & 0.00000000 & 0.00000000 & 0.00000000 \\ 1.001000000 & 0.00015480 & 0.00000000 & 0.00000000 & 0.00000000 & 0.00000000 \\ 0.00000000 & 0.00015480 & 0.00015480 & 0.00000000 & 0.00000000 & 0.00000000 \\ 0.00000000 & 0.00015480 & 0.00046440 & 0.00000000 & 0.00000000 & 0.000000000 \\ 0.00000000 & 0.00015480 & 0.00015480 & 0.000000000 & 0.00000000 & 0.00000000 \\ 0.00000000 & 0.00015480 & 0.00000000 & 0.00000000 & 0.00000000 & 0.00000000\end{array}$


TABLE A-8b.

SEASON 1

STABILITY CATEGORY 2

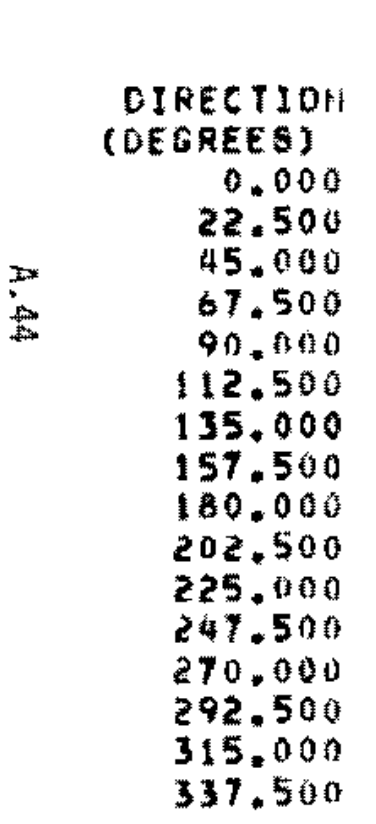

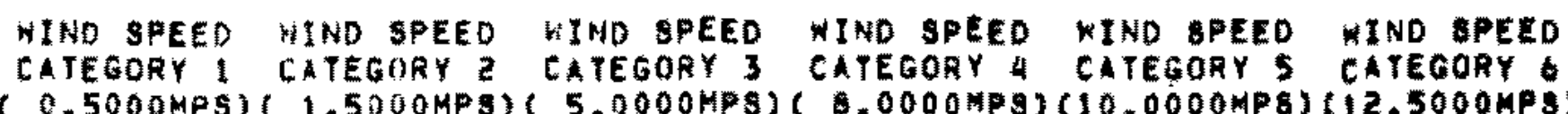

$(0.5000 \mathrm{MPS}) \mathrm{t}$

0.00092879

0.00061920

0.00123839

0.00154799

0.00092879

0.00108359

0.011185759

0.00232196

0.00061920

0.01168359

3. $0010 \mathrm{A3} 59$

0.00108359

0,00046440

0.00061920

0.00123839
$0.0015479 \%$

0.00077399

0.00201236

0.00402477

0.00263158

0.00433437

6.00154799

0.00386997

0.00165759

0.00123839

1).00106359

U. 00247678

0.00139319

娄. 00170279

0.0159799
0.00108359

0.00123639

0.00000000

0.00123839

0.00294118

0.00092079

0.00061920

0.00123839

0.00092079

0.00077399

0.00015480

0.00092870

0.00263158

0.00294118

0.00185759

0.00154799
0.00077399

0.00000000

0.00000000

0.00046440

0.00092879

0.00061920

0.00077399

0.00108359

0.00092879

0.00108359

0.00015480

0.00108359

0.00185759

0.00170279

0.00216716

0,00077399
0.00000000

0.00000000

0.00000000

0.00000000

0.00000000

0.00000000

0.00000000

0.00000000

0.00000000

0.00000000

0.00000000

0.00000000

0.00000000

0.00000000

0.00000000

0.00000000
0.00000000

0.00000000

0.00000000

0.00000000

0.00000000

0.00000000

0.00000000

0.00000000

0.00000000

0.00000000

0.00000000

0.00000000

0.00000000

0.00000000

0.00000000

0.00000000 
TABLE A-8C.

- FKEUUENCY DF DCCURPENCE OF WIND SPEED, DIRECTION AND GTAGLITY

SEASON 1

STABILITY CATEGORY 3

IIN SPEED WINO SPEED WIND SPEED WIND SPEED NIND SPEEO WIND SPEEO CATEGRRY 1 CATEGORY 2 CATEGORY 3 CATEGORY 4 CATECORY 5 CATEGORY

DIRECTIO: (DEGREES)

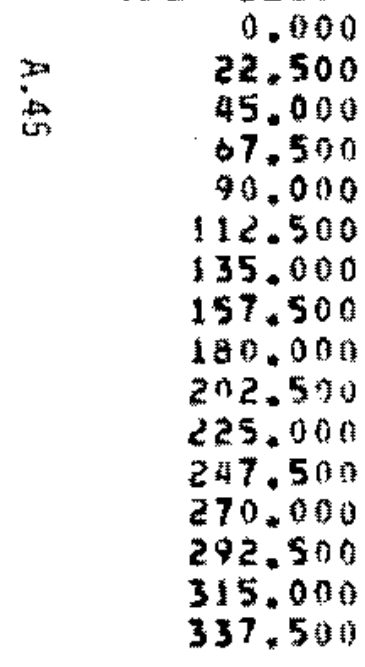


IABLE A-8d.

SEASON 1

STAILITY CATEGORY a

DIfECTIOH (DEGKEES)

0.000

22.500

45.000

67.500

90.000

112.501

135.000

157.500

180.000

$202.50 \%$

225.000

247.500

270.000

292.500

315.000

337.500
WIUA SPEE

CAIEQONY

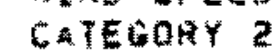

WIND SPEEO

WTO SPEEO

CATEGORY I CATEGORY 4 CATEGORY 5 CATEGORY

WIND SPEED WIND SPEEO

\subsection{0}

0.00000000

1).00000040

0.00015440

0.00015480

0.00000000

0.00015480

0.00015480

0.00030960

i. 00015080

$0.01560040 n$

0.00015480

0.00030960

4. 000309,0

0.01015440

$0.00 \mathrm{cunato}$
0.00139319

0.00061920

0.00015480

0.00015480

0.00123839

0.00139319

0.00123839

0.00170279

0.00201238

0.00123639

0.00139319

0.00154790

0.00108359

0.00077309

0.00077309

0.00092870
0.00077399

0.00046440

0.00046440

0.00108359

0.00294118

0.00712074

0.00681115

0.00433437

0.00619195

0.00526316

0.00557276

0.00464396

0.00170279

0.00276638

0.00294118
0.00433437
0.00046440 0.00046440

0.00046440

0.00030960

0.00495356

0.01609907

0.01346749

0.00990712

0.01114551

0.01702787

0.02105284

0.01578940

0.01547988

0.01424149

0.00866873

0.00541796
0.00046440

0.00000000

0.00061920

0.00325077

0.01563468

0.01687307

0.01377709

0.01253870

0.01873065

0.03204335

0.03467493

0.01996904

0.02198143

0.00727554

0.00263156
0.00030960 
TABLE A-Be.

- FREQUENCY OF OCCURRENCE OF WIND BPEED, DIRECTION AND STAGILITY -

SEASON 1

STABILITY CATEGOAY

WIWD SPEED WIND SPEED WIND SPEED WIND SPEEO WIND OPEEO MIND SPEED
CATEGORY I CATEGORYZ CATEGORY

DIRECTINA (0.5000APS)( $1.5000 \mathrm{MPS})(5.0000 \mathrm{MPS})(8.0000 \mathrm{MPS})(10.0000 \mathrm{MP} 8)(12.5000 \mathrm{MPS})$

CDEGAEESI
0.000
22.500
45.000
67.500
90.000
112.500
135.000
157.500
180.000
202.500
225.000
247.500
270.000
292.500
315.000
317.500

$\begin{array}{ll}0.00000000 & 0.00030960 \\ 0.00000000 & 0.00030960 \\ 0.00000000 & 0.00030960 \\ 0.00000000 & 0.00015480 \\ 0.00000000 & 0.00048440 \\ 0.00000000 & 0.00185759 \\ 0.00000000 & 0.00092879 \\ 0.00000000 & 0.0015479 \\ 0.00000000 & 0.00201238 \\ 0.00000000 & 0.00154799 \\ 0.00000000 & 1.00077399 \\ 0.00000000 & 0.00046440 \\ 0.00000000 & 0.00092879 \\ 0.00000000 & 0.00015480 \\ 0.00000000 & 0.00061920 \\ 0.00000000 & 0.00046440\end{array}$

$0.00108359 \quad 0.00092870$

$0.00092879 \quad 0.00092879$

$0.00030960 \quad 0.00046440$

$0.00061920 \quad 0.00015480$

0.00046440

0.00000000

0.00000000

0.00000000

0.00000000

0.00278630

0.00201238

0.00000000

0.00000000

0.00244118

0.00975232

00000000

0.00000000

0.00433437

0.02662539

0.00000000

0.00000000

0.00340557

0.02260062

0.00000000

0.00000000

0.00356037

0.01625387

0.00000000

0000000

0.00195759

0.01236390

0,00000000

0.00000000

0.00278630

0.00000000

0.00000000

0.00000000

0.00170279

0.00000000

0.00000000

0.00154799

.00000000

0.00000000

0.00000000

0.00000000

0.00000000

0.00000000

$0.00108359 \quad 0.00000000$

0.00000000

0.00000000

$0.00046440 \quad 0.00000000$

0.00000000

000000

$0.00154799 \quad 0.00000000 \quad 0.00000000 \quad 0.00000000$

$0.001547990 .00000000 \quad 0.00000000 \quad 0.00000000$

0.00000000 
TABLE A-8f.

SEASON 1

STABILITY CATEGQRY 6

DIRECTION (DEGREE 3 )

0.000

22.500

$\infty$

45.000

67.500

90.000

112.500

135.000

157.500

180.000

202.500

225.000

247.500

270.000

292.500

315.000

337.500

WIND SPEED CATEGORY

WIND SPEED WIND SPEED
CATEGORY 2 CATEGORY 3

CATEGORY 3

HINO SPEED

CATEGORY 4

WIND SPEED

CATEGORY 5

WIND SPEED

CATEGORY 6

\subsection{0}

0.07046440

0.00092879

0.00123839

0.04046440

$0.0004644 n$

0.00077399

0.00077399

0.00046440

0.00386997

0.00046440

0.00433437

0.00108359

0.00743034

0.00294118

0.01207431

.00309598

0.01466068

0.00278636

0.00046440

0.00402477

0.00077399

0.00309598

0.00309598

0.00061920

0.00046440

0.00247678

0.00232198

0.00030960

0.00185759

0.00170279

\subsection{9}

0.00092879

0.00061920

0.00092879

0.00464396

0.00944273

0.01687307

0.01981425

0.01667307

0.01021672

0.00959753

0.00603715

0.00417957

0.00216718

0.00139319

0.00232198
0.00000000

0.00000000

0.00000000

0.00000000

0.00000000

0.00000000

0.00000000

0.00000000

0.00000000

0.00000000

0.00000000

0.00000000

0.00000000

0.00000000

0.00000000

0.00000000
0.00000000

0.00000000

0.00000000

0.00000000

0.00000000

0.00000000

0.00000000

0.00000000

0.00000000

0.00000000

0.00000000

0.00000000

0.00000000

0.00000000

0.00000000

0.00000000
0.00000000

0.00000000

0.00000000

0.00000000

0.00000000

0.00000000

0.00000000

0.00000000

0.00000000

0.00000000

0.00000000

0.00000000

0.00000000

0.00000000

0.00000000

0.00000000 
APPENDIX B

MODEL MINE 


\section{APPENOL}

MOEE B MIE

Generic inputs are based on the same model mine as given in the october 1984 Background Information Document For final Rules (EPA 1984). Ambrosia Lake meteorological data from the Phillips site were used. Plume rise is bused on average exit size and veloctay fron the 6 of the 14 case study mines with spectfte emission data (uackson et al,1980). The total nodel mine release of II kCilyr is equally divided anong the five model mine vents.

An average mine extt velocity of $16.2 \mathrm{~m} / \mathrm{s}$ and vent diameter of 1.51 m were used based on information available for the case study mines. An exit temperature of 286.83 cegrees Keluin was as sumed. The same value was assumed For anbient temperature.

Tables 8.1 and 8.2 contain concentration output tables for the model mine whout plune rise and with plute rise, respectively. These tables were genarated using the ISCLl code for a polar grta of receptors.

EPA. 984. Radionuclides - Background Information Document For Final Rules, EPA $520 / 1-84-022-2$, U.S. Environmental Protection Agency, washington, D.C.

Jackso et al. 1980. An Investigation of Radon-222 Enissions From Underground Uraniun Mines, PML -3262 , Patific Northwest Laboratory, Richland, washington. 
TABLE B.1. Model Mine Computed Radon Concentrations Without Plume Rise

* DHWULL gROUHD LEYEL CONCENTFATION (PICO CURIES / LITER

I FROM ALL BOURCES COMBINEO

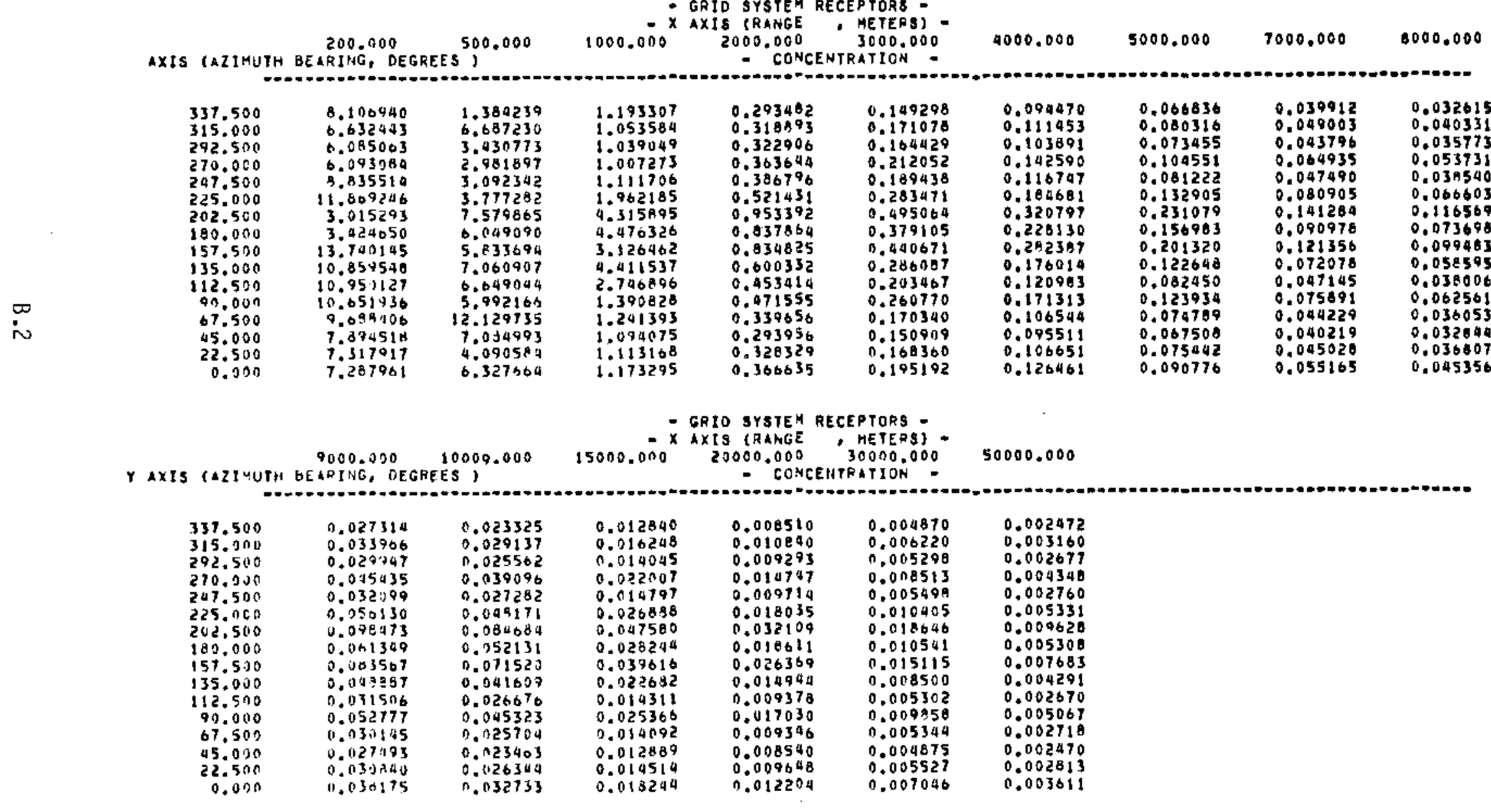


TABLE B.2. Model Mine Computed Radon Concentrations With Plume Rise

* atnul grouato level concentration (pico curies, liter

J FROM ALL DQURCES COMBINED

- GRIO SYSTEM RECEPTORS :

$200.000 \quad 500.000 \quad 1000.000$ PXIS (RANGE, METERS) - CONCENTRMTION

$5000.000 \quad 7000.000$

0000.000

$\checkmark$ AXIS (AZIHUTH PEARING. DEGREES 500 .

$\begin{array}{ll}0.051307 & 0.040546 \\ 0.053008 & 0.047132 \\ 0.053684 & 0.043055 \\ 0.066395 & 0.055956 \\ 0.053709 & 0.043557 \\ 0.077572 & 0.065375 \\ 0.137102 & 0.115743 \\ 0.112912 & 0.089239 \\ 0.148016 & 0.119181 \\ 0.100510 & 0.078122 \\ 0.075346 & 0.056064 \\ 0.105105 & 0.082578 \\ 0.066737 & 0.050969 \\ 0.058487 & 0.044967 \\ 0.069052 & 0.052813 \\ 1.077455 & 0.060744\end{array}$

0.027600

0.029695

0.040900

0.030293

0.047921

0.060507

0.060507

0.052003

0.035530

0.055927

0.033226

0.029702

0.034594

0.041000

0.023495

0.020450

0.035660

0.025913

0.04170

0.051398

0.05738

$0.143916 \quad 0.093286$

$0.144399 \quad 0.095792$

1,077455

0.060744

0.029582

0.027937

0.025061

0.034832

- Gaio SYSTEY AECEPTORS -

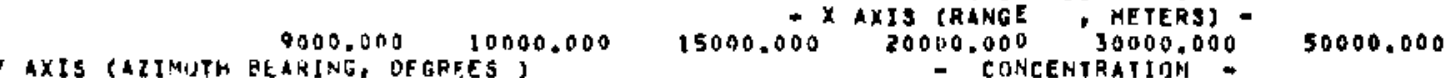
- concentratidin

\begin{tabular}{|c|c|c|c|c|c|c|}
\hline $\begin{array}{r}337.500 \\
315.000 \\
293.500 \\
270.000 \\
247.500 \\
225.000 \\
202.500 \\
180.000 \\
157.530 \\
135.000 \\
112.500 \\
90.001 \\
67.5010 \\
45.000 \\
22.5100 \\
0.000\end{array}$ & $\begin{array}{l}0.020318 \\
0.024796 \\
0.021975 \\
0.031343 \\
0.022079 \\
0.030758 \\
0.065315 \\
0.0144303 \\
0.061973 \\
0.037759 \\
0.025139 \\
0.0711145 \\
0.023933 \\
0.021526 \\
0.024948 \\
0.030770\end{array}$ & $\begin{array}{l}0.017805 \\
0.021861 \\
0.019286 \\
0.027385 \\
0.019747 \\
0.032692 \\
0.058147 \\
0.030309 \\
0.054050 \\
0.032712 \\
0.021717 \\
0.030058 \\
0.020315 \\
0.018759 \\
0.021705 \\
0.020331\end{array}$ & $\begin{array}{l}0.010599 \\
0.013295 \\
0.011515 \\
0.017290 \\
0.011797 \\
0.020369 \\
0.036345 \\
0.022948 \\
0.032474 \\
0.019253 \\
0.012377 \\
0.021499 \\
0.012124 \\
0.010947 \\
0.012646 \\
0.015631\end{array}$ & $\begin{array}{l}0.007291 \\
0.000104 \\
0.007920 \\
0.012125 \\
0.008100 \\
0.014355 \\
0.025730 \\
0.015733 \\
0.022437 \\
0.013110 \\
0.006345 \\
0.014864 \\
0.003270 \\
0.007504 \\
0.008626 \\
0.010773\end{array}$ & $\begin{array}{l}0.004333 \\
0.005444 \\
0.004696 \\
0.007333 \\
0.004795 \\
0.008733 \\
0.015732 \\
0.009721 \\
0.013366 \\
0.007709 \\
0.004056 \\
0.008830 \\
0.004871 \\
0.004420 \\
0.005079 \\
0.000413\end{array}$ & $\begin{array}{l}0.002268 \\
0.002877 \\
0.002449 \\
0.003888 \\
0.002495 \\
0.004671 \\
0.008466 \\
0.004828 \\
0.007009 \\
0.003995 \\
0.002502 \\
0.004683 \\
0.002537 \\
0.002297 \\
0.002642 \\
0.003169\end{array}$ \\
\hline
\end{tabular}


APPENDIX C

CASE STUDY MINES 


\section{APPENDIX C \\ CASE STUDY MINES}

Table C.l summarizes the sources of information for the required characteristics of the 14 modeled mines. Detailed footnotes give additional data as well as the sources of specific mine information used in the modeling. The data sources include reports with mine emission studies, mine safety maps, and information provided by the mining companies. A portion of these data were provided in response to a written request from EPA to the mine owners. Specific release information on vents are not given because some of the information was considered proprietary by mine operators who granted permission to use the mine emissions in this analysis.

As examples of modeling outputs, Tables $C .2$ and $C .3$ contain the listings of radon concentrations computed for case study mines 11 and 12 based on the actual combinations of vertical and horizontal vents for these mines. These tables correspond to Figures 15 and 16 in the main text. Tables C.4 and C.5 contain listings for the same two mines based on assuming all vertical vents. Sinceall concentrations were under $0.1 \mathrm{pCi} / \mathrm{L}$, no contour plots were made for these latter runs. 
TABLE C.1. Sumary of Information Ustod in Modeling Radon Concentration at Selected Mines

Mine

\begin{tabular}{|c|c|c|c|c|c|}
\hline $\begin{array}{l}\text { Cast Study } \\
\text { Mine Number }\end{array}$ & $\begin{array}{c}\text { Specific Emjssion } \\
\text { data }\end{array}$ & Met.(b) & Emisgtans $(c)$ & $\begin{array}{l}\text { Venf } \\
\text { Char. d) }\end{array}$ & $\begin{array}{l}\text { Hent } \\
\text { Loc. }\end{array}$ \\
\hline $1+f$ & No & 1 & $q$ & 99 & a \\
\hline $2(9)$ & Yes & 2 & $n$ & $a z$ & $a$ \\
\hline $3(n)$ & No & 3 & 9 & $9 a$ & a \\
\hline $4(1)$ & No & 3 & $g$ & 59 & $a$ \\
\hline $5(j)$ & No & 4 & 9 & 99 & 9 \\
\hline $6(k)$ & No & 5 & 9 & a a & $a$ \\
\hline $7(1)$ & Yes & 6 & $n$ & ac & $a$ \\
\hline $8(m)$ & No & 6 & n & $a z$ & a \\
\hline $9(n)$ & No & 6 & 9 & ga & $\$$ \\
\hline $10(0)$ & Yes & 6 & 肖 & a & $a$ \\
\hline $11(p)$ & Yes & 7 & m & ad & $a$ \\
\hline $12(a)$ & Yes & 7 & $m$ & a a & a \\
\hline $13(r)$ & No & 8 & $g$ & 99 & a \\
\hline $14(5)$ & Yes & 6 & n & $\mathrm{a} a$ & $\mathrm{a}$ \\
\hline
\end{tabular}

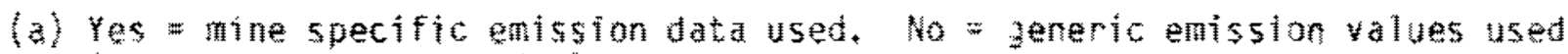

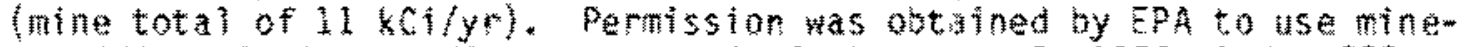
specitic emission studies peported in jackson at al. 1979, Racon-222 Enissions in ventilation Air from Underground Uranium Mines. NUREG/CR0627 , PHL-2888 Rev, Pacific Northwest Laboratory, Richland, washington, and Jackson et al. 1980 An Investigation of Radon-222 Emissions from Underground Mines. NUREG/CR-1273, PNL-3262, PaClfic Northwest laboratory, Richland, Washington. Not all the 1 isted mines were included in these studies.

(b) Meteorological data used in dispersion computatons were taken fron the nearest representative location with data. Fyplcal sources were from the case study nine, or other nearby mines or mills. National weather summaries were used in cases where other closer meteorological data were not identified. The numbers in the table refer to the following data sources.

1 - Cedar city, Utah meteorological input tables were based from two years of surface observations $(1975-1976)$ using data tapes obtained from the 1.5 . Departinent of Comerce. 
2 = Grand Junction stability class data and Uravan wind wind direction/speed data were used. These data were in "A Review of Available Meteorological Data Representative of the Uravan Uranium Mill Site Vicinity" prepared for Union Carbide Corporation, Metals Division, Grand Junction, Colorado.

$3=$ Grand Junction stability class data and Uravan wind speed data and Lisbon wind direction data were used. These data were in "A Review of Available Meteorological Data Representative of the Uravan Uranium Mill Site Vicinity" prepared for Union Carbide Corporation, Metals Division, Grand Junction, Colorado, May 7, 1980 and meteorological data supplied Rio Algom Corporation - Lisbon Mine in a letter to M. 0. Orgill, PNL dated 8-1-1983 from S. L. Wasiter, U.S. Nuclear Regulatory Comission, Region IV, Denver, Colorado.

4 - Casper, Wyo. meteorological input tables were based from two year of surface observations (1975 - 1976) using data tapes obtained from the U.S. Department of Commerce.

5 = La Polvadera Valley data obtained in Mt. Taylor Uranium Mill Project, New Mexico, Volume 4 Radiation Safety Program and Appendicies, Gulf Mineral Resources Co., Denver, Colorado, no date.

$6=$ Gallup NM summaries for $1 / 76$ to $12 / 80$ obtained from the U.S. Department of Commerce is given in Uranium Mill License Renewal Application, Environmental Report, Church Rock Mill, License No. NM-UNC-ML, state of New Mesico, Environmental Improvement Division, Dec. 1981.

7 = NMEID Phillips Site, data in attachment 9 of letter dated $8 / 18 / 83$ to Mr. R. J. Guimond, USEPA from W. J. Shelly, Kerr-MCGee Corporation.

8 = Nose Rock meteorological data were obtained in "Nose Rock Project, Vo: ume 3, Attachments to Uranium Mill License Application", Phillips Uranium Corporation, no date. These data are a combination of onsite wind measurements cloud cover information at Albuquerque, NM for the period $8 / 22 / 76$ to $8 / 8 / 77$.

(c) Radon emission rate from the mine; $m$ m measured data in PNL study, $g=$ generic total mine release of $11 \mathrm{Ci} / \mathrm{yr}$ equally divided between vents.

(d) Vent release characteristics for total exhaust flow and exit diameter respectively; $\mathrm{a}=$ actual, $\mathrm{g}=$ generic.

(e) Vent locations relative to main shaft were based on; a = actual location, $\mathrm{g}$ = generic spacing. 
(f) Mine 1 thack Camyon:

Number of vents based on information supplied by w* 0 . Hatchell, staff Geologist, State of New Mexico, Energy and Mineral Department in letter dated 7-21-83. Pages were supplied from the document Uranium Resources and Technology, A Review of the New Mexico Uranium Industry, 1980, New Mexico Energy and Mineral Department, Santa Fe, Kew Maxico.

(a) Mne 2 (Deremo-Synder):

Measured vent and enission data (see foothote defined using a map supplied as an enclosure in a letter dated $8-17-83$ to Mr. R. U. Guimond, USEPA fron R. G. Beverly, Union Carbide Corporation.

(h) Mine $3(\operatorname{LaSa} 1)$ :

Vent locations and diameters were taken from map labeled "Deer Creek Group, La Sal and Snowal? Areas, Union Carbide Corporation, Metals livision, Uravan, Colorado" dated $3-22-83$. The diviston between mines was uncertain on this map. The two vents with snowall writwen near them and in the ytinty of the Snowbll Portal were not included in the La Sal vents; all the rendinting vents labeled on this map were wed in the modeling of radon concentrations for La $\$$ lal. Generic flow rates and actual exit dianeters used.

(i) Mine 4 (Hecla):

Vent locations were taken from map labeled "Reclanation Map, U.C.C.. Hecla Joint Venture, Union Carbice Corporation, Metal Division, Uravan tated $13-13-78$.

(1) Mines (Sheep Mountain):

Generic vents and emissions were used.

(k) Mine 6 (Mt. Taylor):

Flow rates were based on afformation supplled by w.0. Hatchell, Stat? Seologist, State of New Mexico, Energy and Mitneral Department in leter dated $7-21-83$. Pages were supplted fron the document Urantun Resoures and Technology, A Review of the New Mexico Uranim Industry, 1980, New Mexico Energy and Minera Department, Santa Fe, New Mexteo. Size of shat was taken from maps labeled "Wentflation and Escape plan, Gulf Mineral resources Co*, Mt. Taylor Mine Project, San Mateo, New Mexico.

(1) Mine 7 (otd Church Rock):

A vent location map was not obtained for this mine. The emissions from the seven vents measured in the PNL study were modeled in a generic pattern based on the spacing of the vents at other mines in this inmediate area. 
(m) Mine 8 (Church Rock NE):

Number of vents and total flow are from information supplied by w. 0 . Hatchel1, Staff Geologist, State of New Mexico, Energy and Mineral Department in letter dated 7-21-83. Pages were supplied from the document Uranium Resources and Technology, A Review of the New Mexico Uranium Industry, 1980, New Mexico Energy and Mineral Department, Santa Fe, New Mexico.

(n) Mine 9 (Church Rock East):

Church Rock East was part of CR \#1 when PNL measured emissions. The East shaft was under construction, and one vent from the East mine was operating as part of Church Rock \#1. This vent is one of two exhaust vents shown for the East Shaft in a Ventilation Map for Kerr-McGee Corporation Church Rock Operations, dated 9-1-78. Vent locations were taken from "Ventilation Map, Kerr-McGee Corporation, Church Rock Uranium Operations" dated 8-1-78.

Generic emission rates were used to model this mine.

(o) Mine 10 (Church Rock 1):

Measured vent and emission data (see footnote (a)). Vent locations were taken from "Ventilation Map, Kerr-McGee Corporation, Church Rock Uranium operations" dated 8-1-78. Modeled as operating when measurements were made (see footnote $(n)$ ).

(p) Mine 11 (Kerr McGee Sec. 30 East, NM):

Measured vent and emission data (see footnote (a)).

(q) Mine 12 (Kerr McGee Sec. 30 West, NM

Measured vent and emission data (see footnote (a)).

(r) Mine 13 (Nose Rock):

Nose rock has two mines (\#1 \& \#2) located about $3 / 4$ mile apart: \#1 was modeled.

(s) Mi ve 14 (Mariano Lake):

Measured vent and emission data (see footnote (a)). Vent locations were defined using a map supplied as an enclosure in a letter dated 8-12-83 to $\mathrm{Mr}$. R. J. Guimond, USEPA from S. A. Zagnoli, Gulf Mineral Resources Co. 
TABLE C.2. Radon Concentration Listings for Case Study Mine 11 Based on Actual Vent Orientation

* andual gadund level coneentration i pico cuages per liter

J FROM ALL SOURCES COMBINED

- grio ststem recepturs -

\begin{tabular}{|c|c|c|c|c|c|c|c|c|c|}
\hline $\left.15(12]^{\mu}\right) t$ & $\begin{array}{l}200.000 \\
\text { RIHG. DEG }\end{array}$ & )$^{50 n .000}$ & 1000.000 & $\begin{array}{c}000.000 \\
=\quad \text { COHCE }\end{array}$ & $\begin{array}{l}1000.000 \\
1710 N\end{array}$ & 4000.000 & 5000.000 & 7000.000 & 8000.000 \\
\hline $\begin{array}{l}337.500 \\
315.090 \\
272.500 \\
279.090 \\
247.500 \\
225.0100 \\
202.500 \\
190.0013 \\
157.500 \\
135.019 \\
112.5011 \\
919.090 \\
67.500 \\
45.000 \\
22.500 \\
0.000\end{array}$ & $\begin{array}{l}1.870961 \\
1.264944 \\
1.005350 \\
0.337621 \\
0.744569 \\
0.707108 \\
0.811165 \\
0.973956 \\
1.252714 \\
1.613156 \\
2.19457 \\
2.739759 \\
2.991840 \\
2.320549 \\
1.775768 \\
2.012772\end{array}$ & $\begin{array}{l}0.433408 \\
1.025570 \\
0.627947 \\
0.474777 \\
0.462768 \\
0.460233 \\
0.510650 \\
0.064911 \\
0.115014 \\
0.707715 \\
1.201396 \\
2.509021 \\
7.218555 \\
0.306828 \\
2.521598 \\
2.192571\end{array}$ & $\begin{array}{l}0.330249 \\
0.249430 \\
0.265410 \\
0.194153 \\
0.206826 \\
0.263538 \\
0.305579 \\
0.323835 \\
0.302072 \\
0.420421 \\
0.414239 \\
0.356436 \\
0.651119 \\
0.500684 \\
0.533386 \\
0.406545\end{array}$ & $\begin{array}{l}0.105484 \\
0.093995 \\
0.091083 \\
0.087283 \\
0.072297 \\
0.115942 \\
0.166384 \\
0.149472 \\
0.166851 \\
0.163880 \\
0.133090 \\
0.155427 \\
0.137269 \\
0.121579 \\
0.304089 \\
0.159833\end{array}$ & $\begin{array}{l}0.057997 \\
0.057202 \\
0.055351 \\
0.060004 \\
0.008195 \\
0.076637 \\
0.1114122 \\
0.101053 \\
0.116439 \\
0.095335 \\
0.074519 \\
0.097047 \\
0.070875 \\
0.066485 \\
0.078017 \\
0.080395\end{array}$ & $\begin{array}{l}0.039411 \\
0.040991 \\
0.039210 \\
0.046009 \\
0.035521 \\
0.057311 \\
0.089274 \\
0.073660 \\
0.089532 \\
0.066896 \\
0.050192 \\
0.079142 \\
0.047980 \\
0.042311 \\
0.049654 \\
0.054456\end{array}$ & $\begin{array}{l}0.027449 \\
0.031906 \\
0.030124 \\
0.037228 \\
0.028179 \\
0.045450 \\
0.073104 \\
0.057353 \\
0.072334 \\
0.051152 \\
0.037242 \\
0.054509 \\
0.035332 \\
0.031255 \\
0.036610 \\
0.041301\end{array}$ & $\begin{array}{l}0.019132 \\
0.021795 \\
0.020109 \\
0.026603 \\
0.019383 \\
0.031793 \\
0.053105 \\
0.038972 \\
0.051302 \\
0.034110 \\
0.023714 \\
0.037212 \\
0.022946 \\
0.020218 \\
0.023658 \\
0.027456\end{array}$ & $\begin{array}{l}0.016162 \\
0.018722 \\
0.017118 \\
0.023130 \\
0.010649 \\
0.027516 \\
0.046590 \\
0.033344 \\
0.044504 \\
0.029027 \\
0.020075 \\
0.031993 \\
0.019273 \\
0.017046 \\
0.019939 \\
0.023357\end{array}$ \\
\hline
\end{tabular}

\begin{tabular}{|c|c|c|c|c|c|c|}
\hline 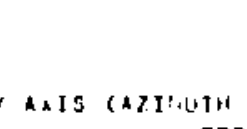 & 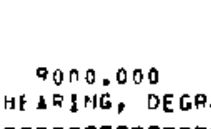 & $\begin{array}{l}10009.000 \\
\text { (ES) }\end{array}$ & $15000.000^{x}$ & $\begin{array}{r}\text { GRID SYSIEH } \\
\text { AXIS SRANGE } \\
20000.000 \\
-\quad \text { CONCE }\end{array}$ & $\begin{array}{l}\text { RECEPTORS - } \\
\text { 'HETERSI- } \\
\text { 3NOOOOONO } \\
\text { ENTRATION - }\end{array}$ & 50000.000 \\
\hline $\begin{array}{r}337.500 \\
315.000 \\
392.500 \\
270.040 \\
207.500 \\
225.000 \\
202.500 \\
190.000 \\
157.500 \\
135.000 \\
112.500 \\
70.000 \\
67.500 \\
45.000 \\
22.500 \\
0.000\end{array}$ & $\begin{array}{l}0.013935 \\
0.016351 \\
0.014841 \\
0.020422 \\
0.011431 \\
0.024180 \\
0.041332 \\
0.029000 \\
0.039130 \\
0.025148 \\
0.017198 \\
0.027789 \\
0.016540 \\
0.014672 \\
0.017155 \\
0.020246\end{array}$ & $\begin{array}{l}0.012204 \\
0.014466 \\
0.013055 \\
0.013222 \\
0.012852 \\
0.021518 \\
0.037061 \\
0.025569 \\
0.034805 \\
0.022103 \\
0.014975 \\
0.024536 \\
0.014429 \\
0.012930 \\
0.014995 \\
0.017407\end{array}$ & $\begin{array}{l}0.007350 \\
0.00897 t \\
0.007956 \\
0.011602 \\
0.007944 \\
0.013626 \\
0.023986 \\
0.015645 \\
0.021870 \\
0.013395 \\
0.008806 \\
0.015055 \\
0.008566 \\
0.007674 \\
0.008945 \\
0.010443\end{array}$ & $\begin{array}{l}0.005135 \\
0.006363 \\
0.00555 \\
0.008330 \\
0.005606 \\
0.009791 \\
0.017428 \\
0.010994 \\
0.015560 \\
0.009356 \\
0.006056 \\
0.010692 \\
0.005936 \\
0.005337 \\
0.006210 \\
0.007619\end{array}$ & $\begin{array}{l}0.003123 \\
0.003921 \\
0.003408 \\
0.005207 \\
0.003437 \\
0.006132 \\
0.011023 \\
0.006698 \\
0.009614 \\
0.005667 \\
0.003607 \\
0.006517 \\
0.003571 \\
0.003222 \\
0.003740 \\
0.004651\end{array}$ & $\begin{array}{l}0.001680 \\
0.002130 \\
0.001835 \\
0.002863 \\
0.001255 \\
0.003391 \\
0.006147 \\
0.003601 \\
0.005224 \\
0.003026 \\
0.001902 \\
0.003526 \\
0.001902 \\
0.001720 \\
0.001973 \\
0.002509\end{array}$ \\
\hline
\end{tabular}


IABLE_C.3. Radon Concentration Listings for Case Study Mine 12 Based on Actual Vent Orientation

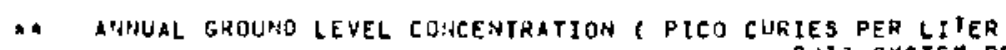

I FROH ALL SOURCES COHBINEO

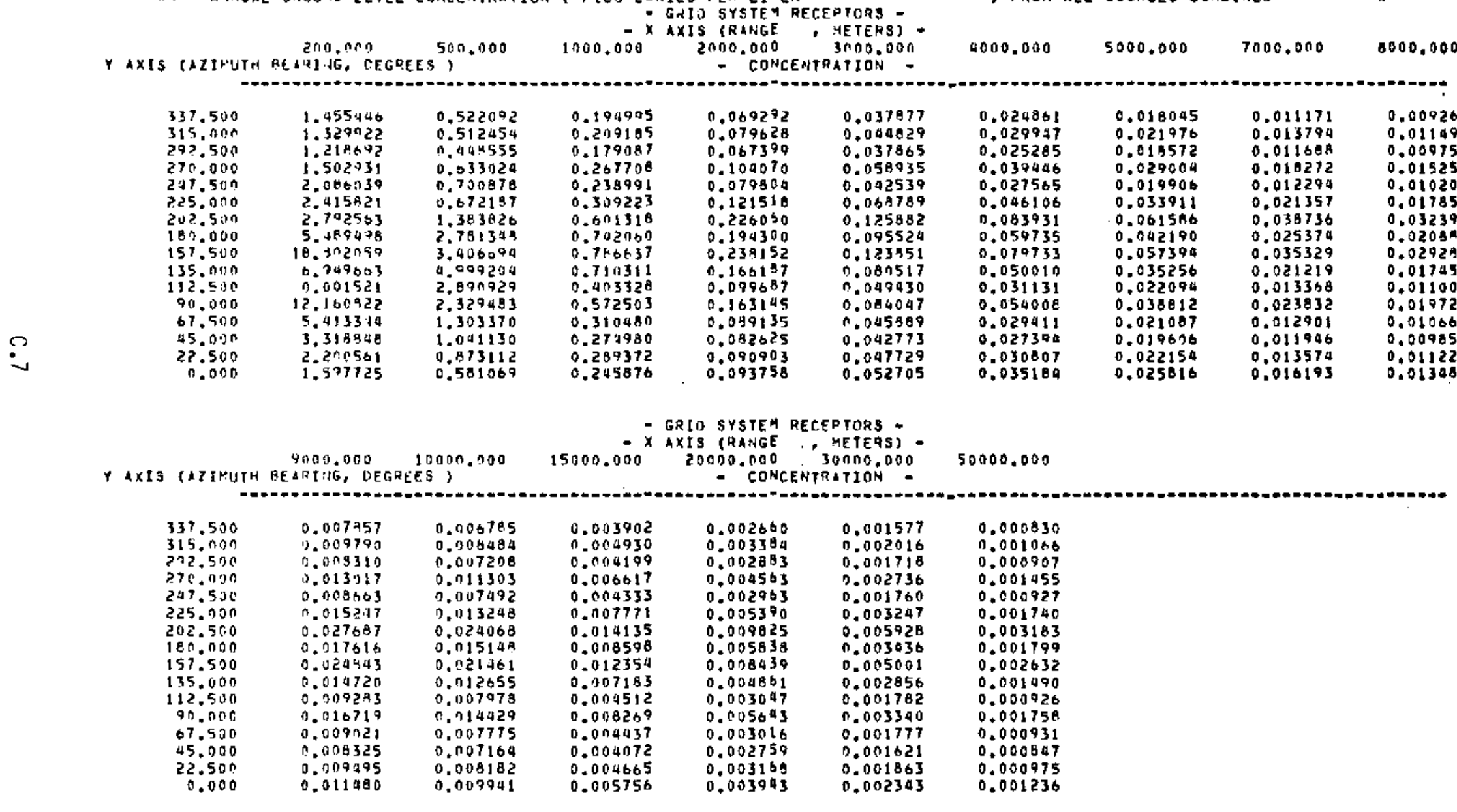


TABLE C.4. Radon Concentration Listings for Case study Mine 11 with All Vertical vents

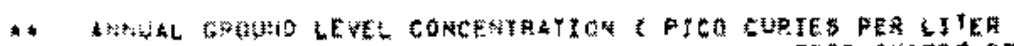

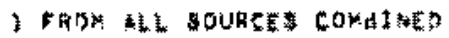

**

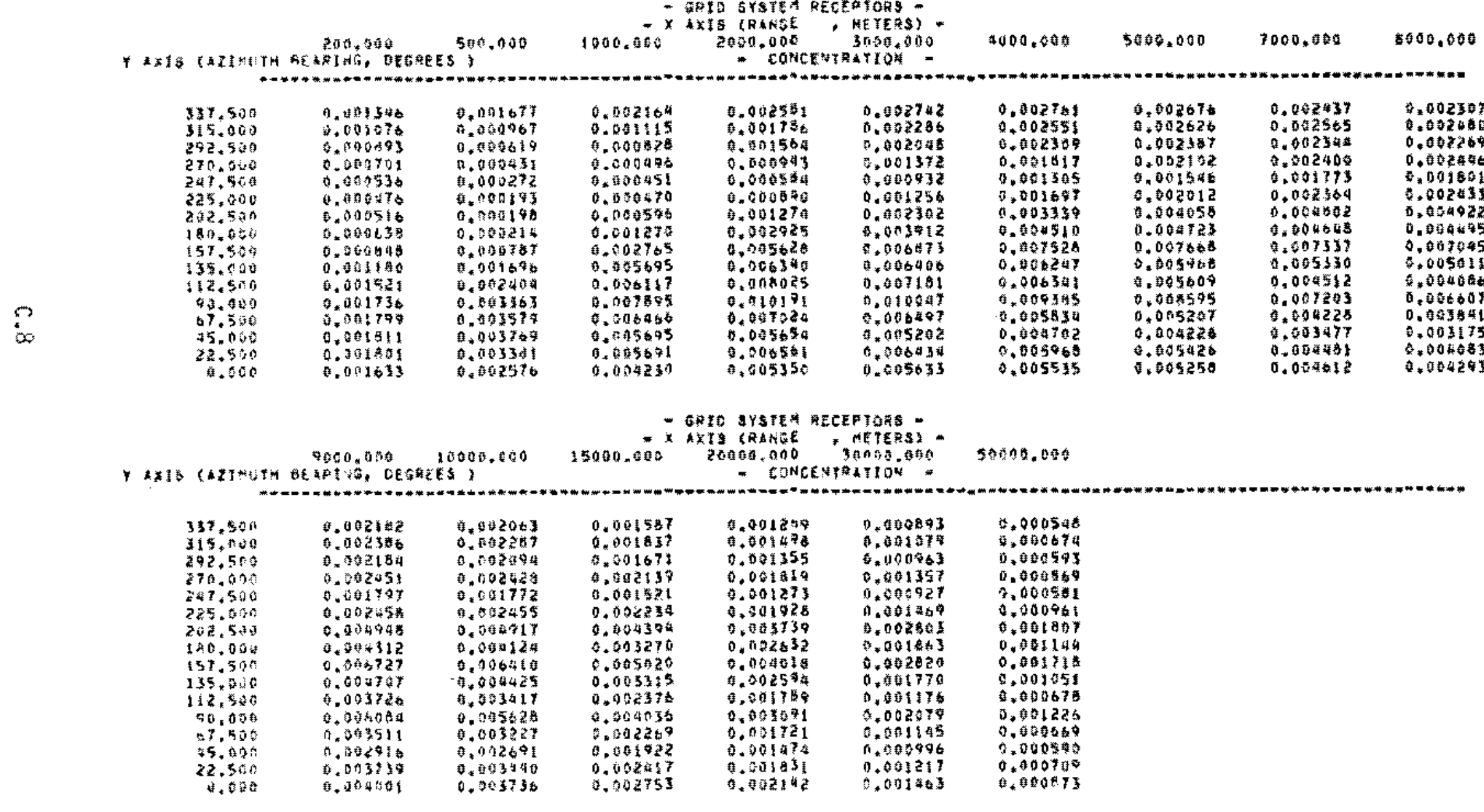


TABLE C.5. Radon Concentration Listings for Case Study Mine 12 With All Vertical Vents

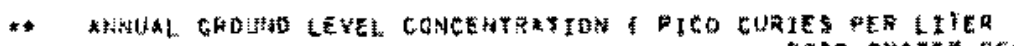

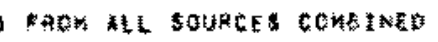

\begin{tabular}{|c|c|c|c|c|c|c|c|c|c|c|}
\hline $1 \times 15$ & (k) & 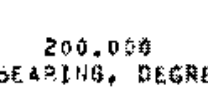 & 50.000 & 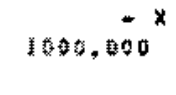 & 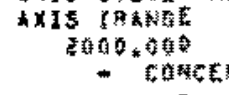 & 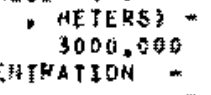 & 0000,000 & 5000,000 & 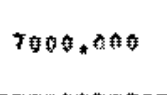 & 8006.000 \\
\hline & 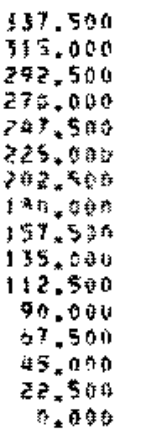 & 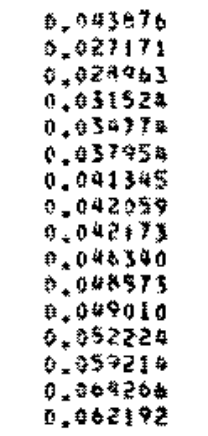 & 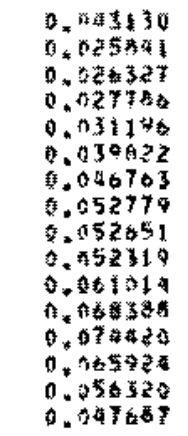 & 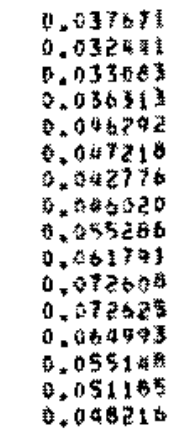 & 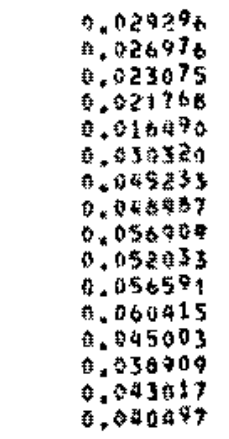 & 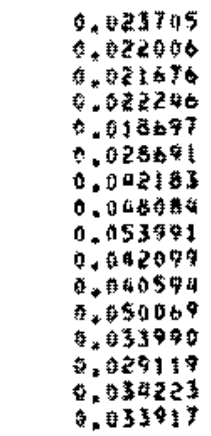 & 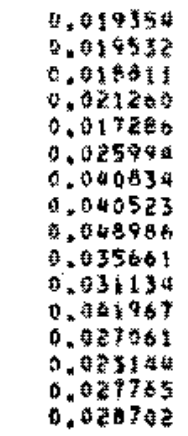 & 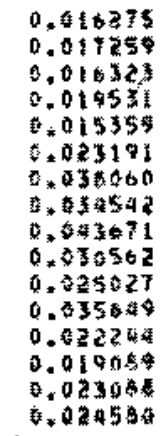 & 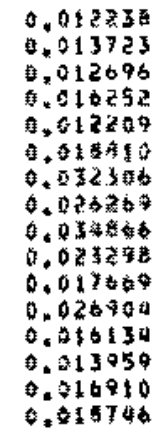 & 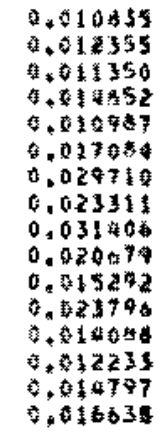 \\
\hline & $(42964)$ & 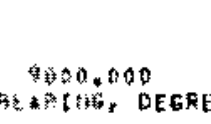 & $\begin{array}{l}\text { I0000* } \\
\text { EES }\end{array}$ & 15000.0000 & 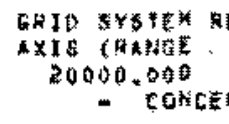 & 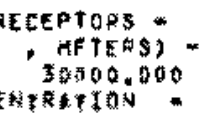 & 300000000 & & & ' \\
\hline & 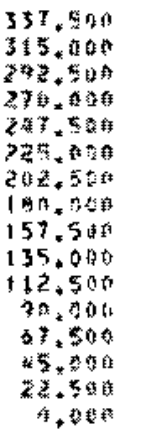 & 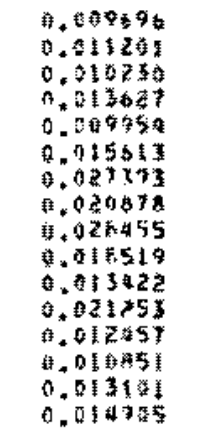 & 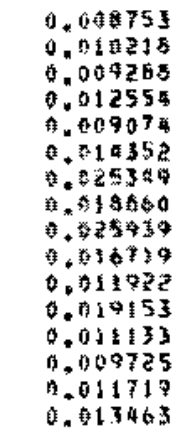 & 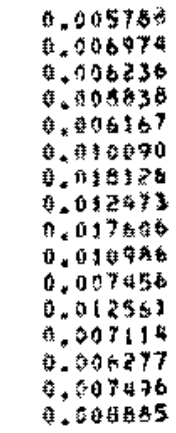 & 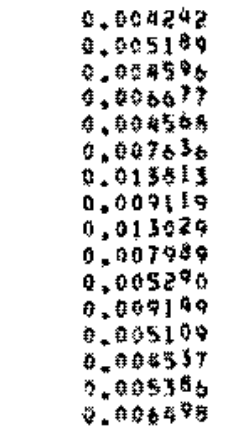 & 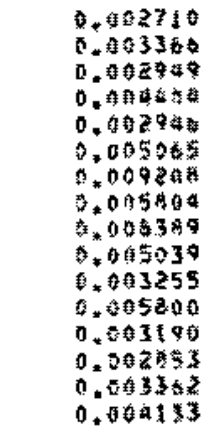 & 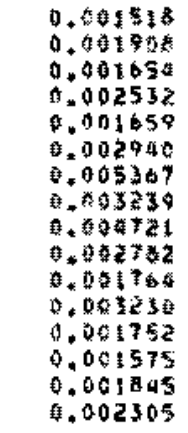 & & & \\
\hline
\end{tabular}


3

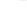
it 


\section{DISTRIBUTION}

No. of

Coples

30 DoE Technical Information Center

20 Jay Silhanek

General Radiation standards Branch (ANP-460)

rriterea and Standards Division

office of Radiation Programs

i. S. Environmental Protection Agency

Washington, OC 20460

ONSITE

DoE Richland Operations office

H. E. Ransom
No. af

Copies

33 Pacific Northwest Laboratory

C. H. Bloomster

0. Dragnich

J. G. Droppo $(20)$

3. A. Glissmeyer

P. C. Hays

P. 0. Jackson

N. S. Laulainen

Technical Publication (5)

Publishing Coordination (2) 


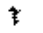

** 